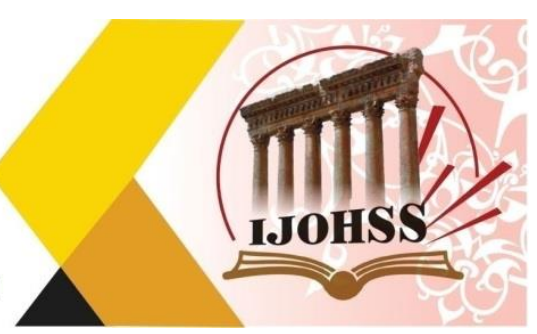

\title{
اختلاف القراءات واثرها في التفسير الموضوعي
}

\author{
المدرس المساعد \\ مهري حسين مهدي

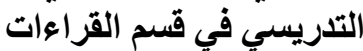 \\ كليّة الإمام الأعظم الجامعة المات

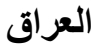

الملخص

الحمد لله الذي شرح صدور أهل الإيمان بالهدى، ونكت في قلوب أهل الطغيان فلا تعي الحكمة أبدا، وأثهد أن

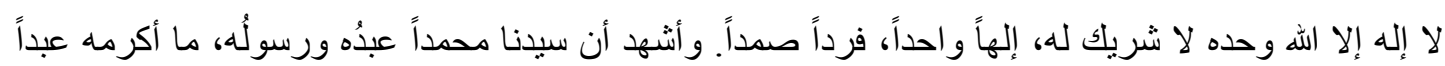

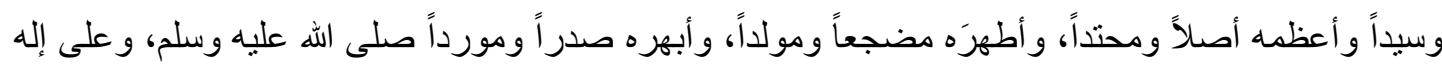

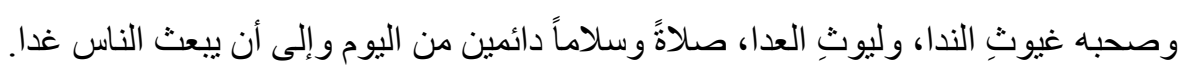

إن التفسير الموضوعي هو الجزء المعاصر من تفسير القرآن الكريم، والقراءات القرآنية تمثّل الخطوة الأولى ميلى في فهم القرآن، وهي باب التفسير، ومدرجه، وتثكّل مع التفسير الموضوعي حدود حرم التفسير بميدانه الرحب لهب

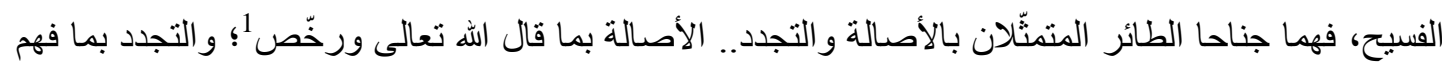
من التلقّي كلّه. ولمّا كان التفسير الموضوعي بأنواع ثلاثة تتمثّل بالمفردة والموضوع و السورة القرآنية، فلا يخرج تأثثير

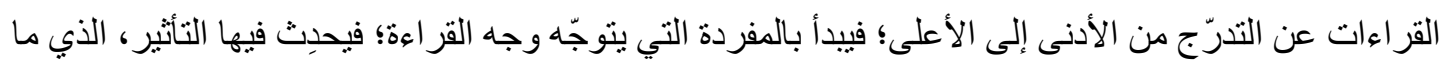

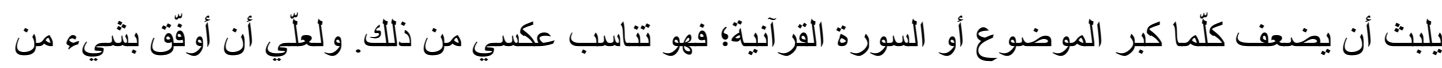
العرض و التبسيط لهذه القضايا.. و اله هو الهادي إلى سبيل الرضوان وزيادة.

الكلمات المفتاحية: اختلاف القراءات، التفسير الموضوعي.

1 إثارة إلى الرخصة بقر اءة القرآن على أحرف سبعة 


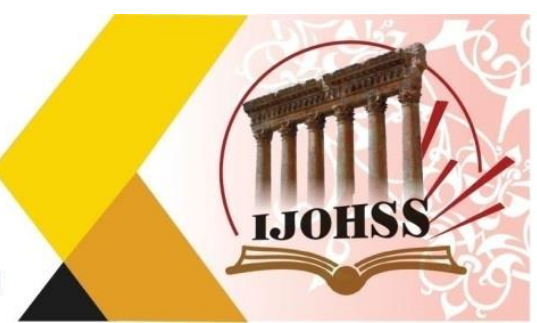

\title{
The Difference in Readings and their Impact on the Objective Interpretation
}

\author{
Assistant Lecturer \\ Mahdi Hussein Mahdi \\ Instructor in the reading department \\ Imam Al-Azam University College \\ Iraq
}

\begin{abstract}
Praise be to God, who explained the chests of the people of faith with guidance, and spoke in the hearts of the people of tyranny, so wisdom is never aware, and I bear witness that there is no god but God, alone, without partner, one God, alone, enduring. And I bear witness that our master Muhammad is his servant and his messenger, the most honorable of his servant and master, the greatest in origin and unity, the purest in his bed and at birth, and the most radiant in his heart and source, may God's prayers and peace be upon him.

The objective interpretation is the contemporary part of the interpretation of the Noble Qur'an, and the Qur'anic readings represent the first step in understanding the Qur'an, which is the chapter on interpretation, and its contents. Together with the objective interpretation, it forms the boundaries of the sanctuary of interpretation in its spacious field. They are the two wings of the bird represented by originality and renewal.. Authenticity with what God Almighty said licensed; And renewing what they understood from receiving it all.

Since the objective interpretation is of three types, represented by the singular, the subject and the Qur'anic surah, the effect of the readings does not go beyond the gradation from the lowest to the highest; It begins with the singular that directs the face of reading; The effect occurs in it, which soon weakens the larger the subject or the Qur'anic surah; It is an inverse proportion to that. Perhaps I can reconcile with some presentation and simplification of these issues.. God is the Guide to the path of contentment and more.
\end{abstract}

Keywords: different readings, objective interpretation. 


$$
\begin{aligned}
& \text { المبحث الأوّل } \\
& \text { التعريف بعلم القراعات والتفسير الموضوعي } \\
& \text { المطلب الأوّل }
\end{aligned}
$$

علم القراعات (تعريفه ــ أهميّهـه ــ أقسام القراءات ـ أسماء القرّاء العشرة مع رواتهم) تعريف القراعات التراعات

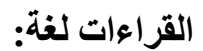

جمع قراءة، والقراءة في اللغة مشتقة من مادة (ق ر أ) وهي مصدر للفعل (قرأ)، يقال: قرأ يقر أ قرءاناً

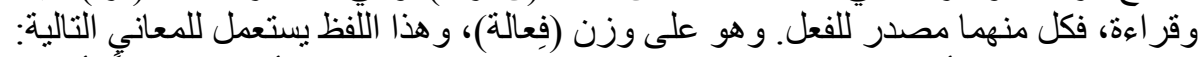

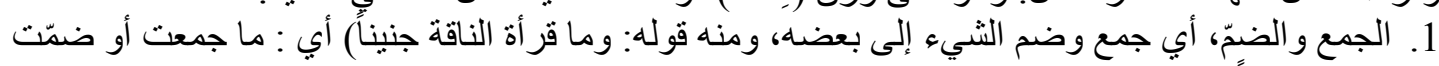
في رحمها جنيناً. 2. التتلاوة، وهي النطق بالكلمات المكتوبة، ومنه قولهم: (قرأت الكتاب)، أي: تلوته، وسمّيت التلاوة قراءة؛

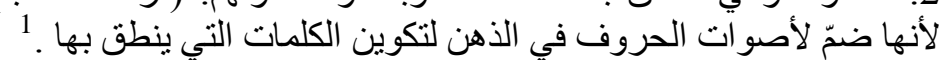

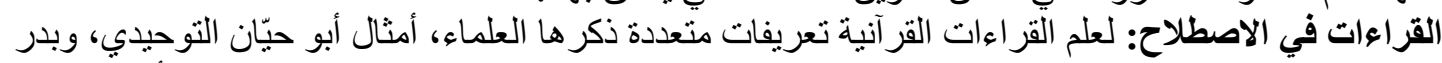

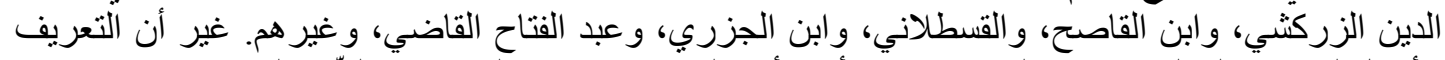

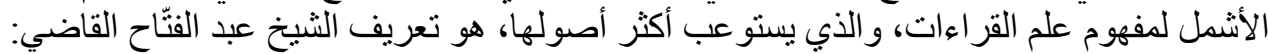

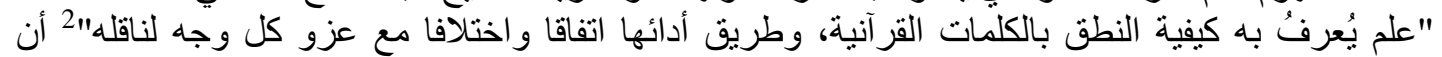

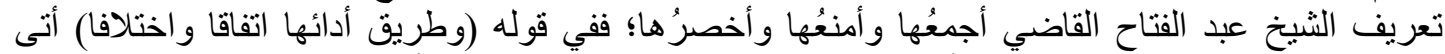

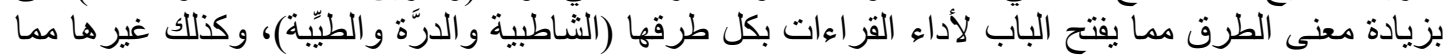

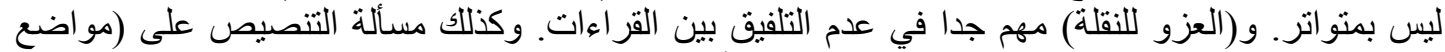

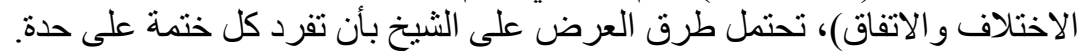

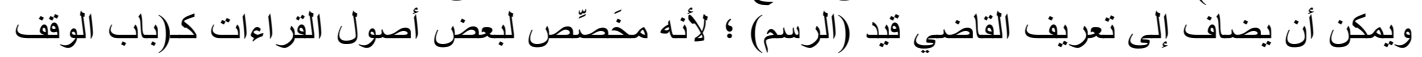

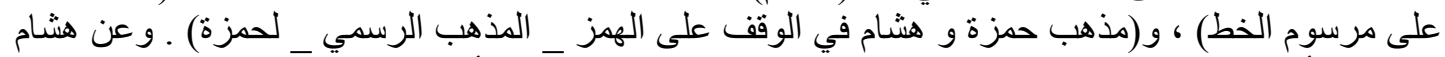

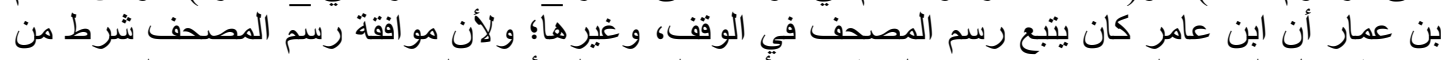

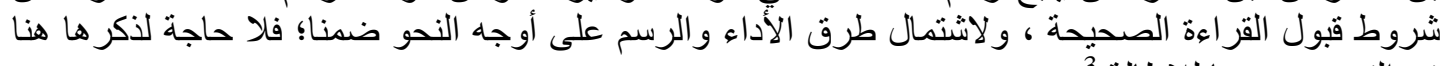

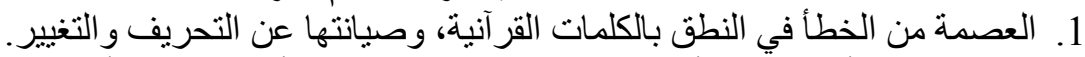

2.

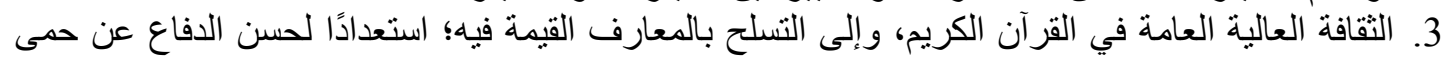

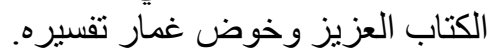

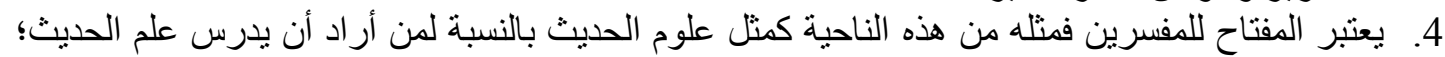

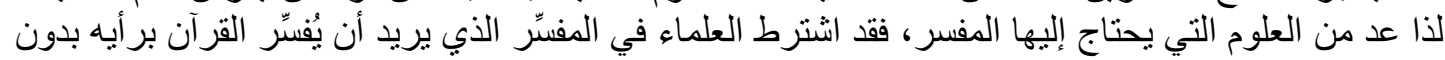

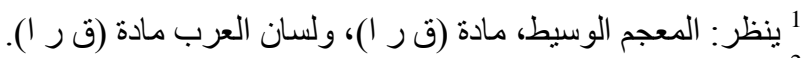

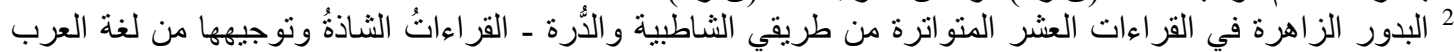

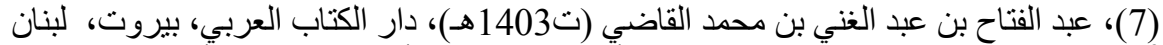
3 ينظر : الإقناع في القراءات السبع (254)، أحمد بن علي بن أحمد بن خلف خلف الأنصاري الغرناطي، أبو جعفر، المعروف

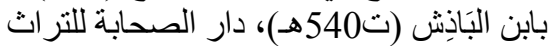
4 ينظر: مباحثث في علم القراءات (25 - 33)، عبد العزيز بن سليمان المزيني، دار كنوز أثنبيليا، الطبعة الأولى، 2011م. 


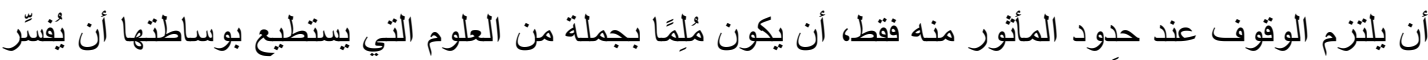

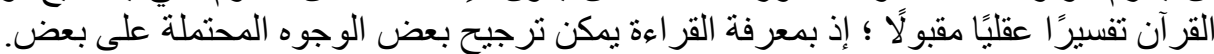

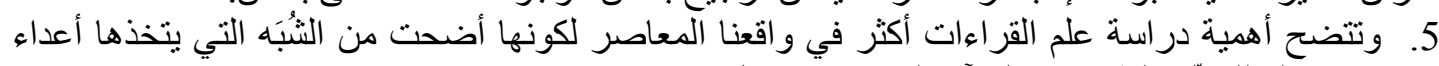

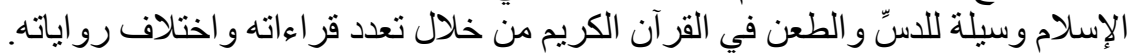

أقسام القزاعات 1 أقات

تنقسم القر اءات القر آنية التي وصلت إلينا إلى المقبولة، و المردودة:

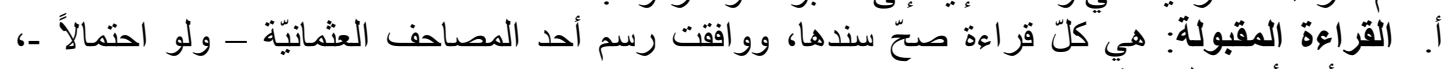
وو افقت أحد أوجه العربية.

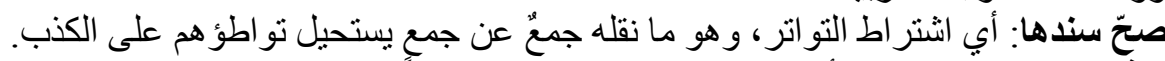

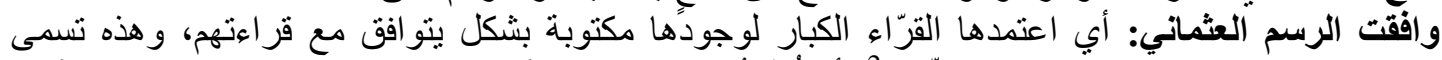

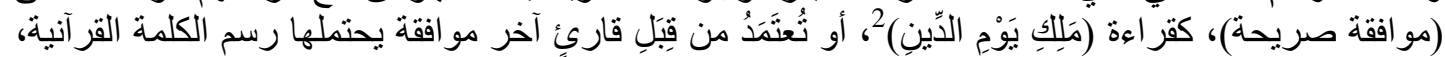

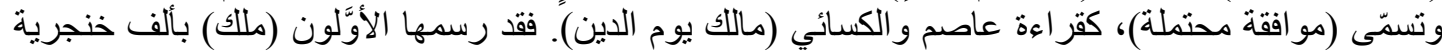

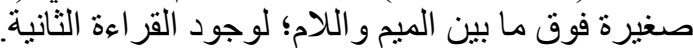
وافقت أحد أوجه العربية: لا يعني ذللك أن قواعد اللغة العربية حاكمة على القرآن؛ و إنما جاء القرآن مؤكدا لما ألفه العرب من أوجه كلامهر.

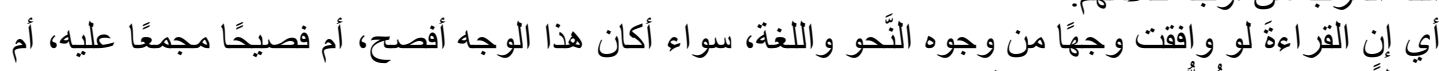

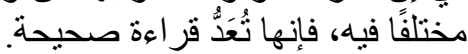

\section{التعريف بالقراء ورواتهمج 3}

فإن القراء الذين تو اترت قر اءاتهم وتلقتها الأمة بالقبول هم عشرة ، ولكل منهم راويان هما أثشر من روى عنه. 1-نافع: وهو أبو رؤيم قارئ المدينة من تابعي التابعين توفي في المدينة: 196هـ.

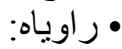

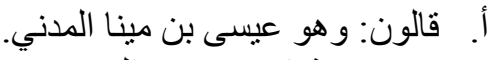
ب. ب. ورش: عثمان بن سعيد المصري.

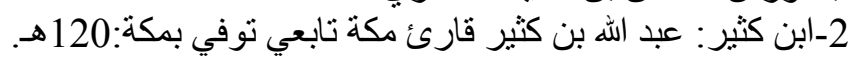

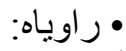

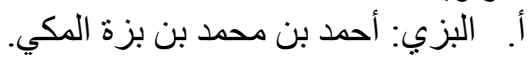

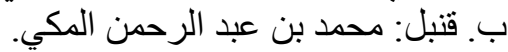

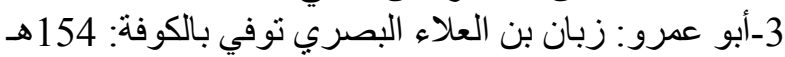

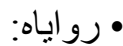

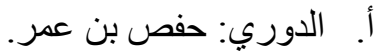

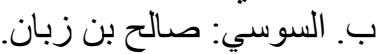
4- رابن عامر: عبد الله بن عامر تابعي دمثقي توفي بهان سنة 118هـ

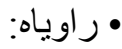
أ. ـثام: بن عمار الدمشقي.

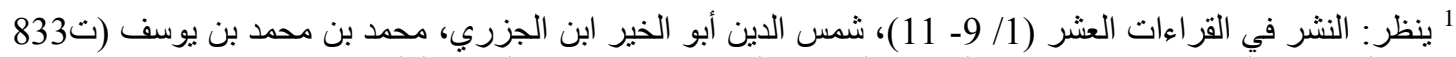

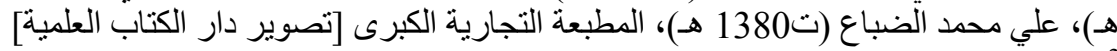

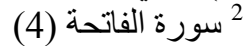
3 ينظر: البدور الزاتهرة في القراءات العشر المتواترة (7- 9) 


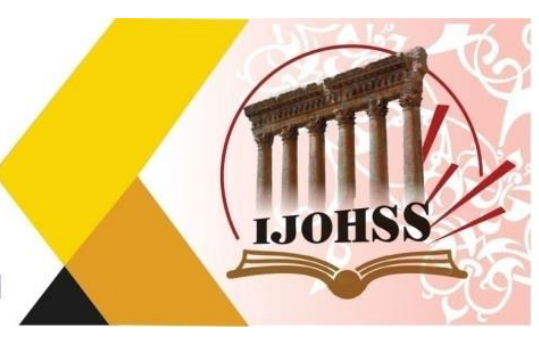

ب. ب. ابن ذكوان: عبد الله بن أحمد القرشي. 5-عاصم بن أبي النجود: تابعي قارئ الكوفة النة وبها توفي سنة: 128 هـ

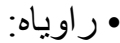
أ. شعبة: أبو بكر بن عياش الكوفي.

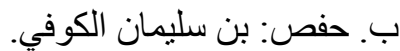
6-حمزة بن حبيب الزيات: من قر اء الكوفة:156 هـ فـ • راوياه:

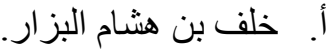
ب. خلاد بن خالد الصيرفي. 7ـالكسائي: علي بن حمزة النحوي من فر اء الكوفة توفي: 189 هـ

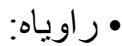
أ. أبو الحارث الليث بن خلد.

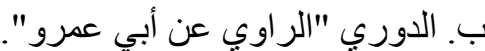

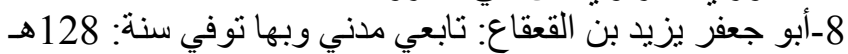

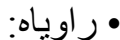
أ. ابن وردان عيسى بن وردان إن المدني.

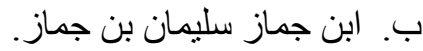
9-يعقوب بن إسحاق الحضرمي البصري بن جمان توفي بها سنة: 205هـ • راوياه: أ. رويس محمد بن المتوكل اللؤلؤي.

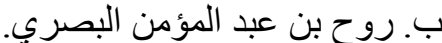
10-خلف بن هشام البزار البغدادي بها توفي سنة: 229

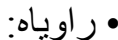

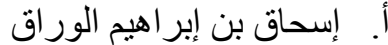

$$
\text { ب. إدريس بن عبد الكريم الحداد. }
$$

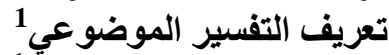

إن كلمة التفسير الموضوعي تتألف من جزأين ركّبا تركيبا وصفيّاً، فلا بدّ من تعريف كلّ جزء من هذين

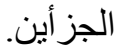
التفسير (لغة): من الفسر ؛ وهو الكثف و البيان، و إظهار المعنى المعقول. و التفسير مبالغة من الفسر.

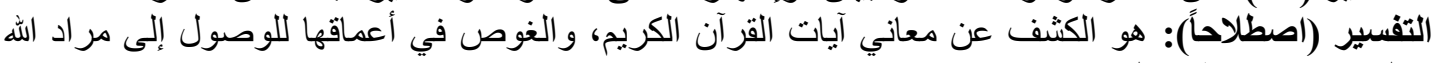
تعالى منها بقدر طاقة البشر.

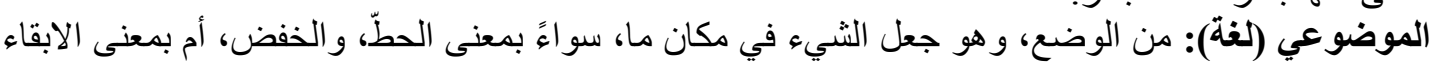
و التثبيت بالمكان. الموضوعي (اصطلاحاً)² هو جمع الآيات المتفرقة في سور القرآن، المتعلّقة بالموضوع الواحد، لفظاً أو حكماً، وتفسير ها حسب المقاصد القرآنية.

1 ينظر (عدا التعريف الاصطلاحي للتفسير الموضوعي): محاضر ات في التفسير الموضوعي (18- 19)، عباس عوض الإض

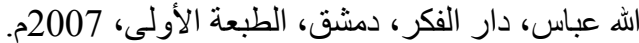
2 مباحث في التفسير الموضوعي (16)، مصطفى الفى مسلم، دار القلم، دمشق، الطبعة السادسة، 2009م. 

3 3. تأصيل الدراسات القرا آنيّة و العلميّة.

4. تأهيل مسار الدراسات الدينيّة والعربيّة القائمة، وتصحيحها، وضبطها وفق الهدائة العات القر آنية. 5. 5 ترسيخ مبدأ تفسير القرآن بالقر آن.

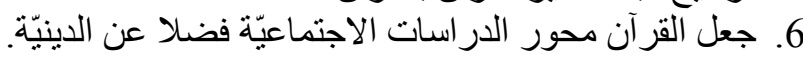

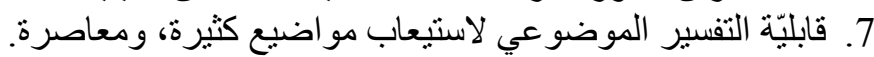
8. الوفاء بمنطلبات العدد المتز لايد من الجامعات و المر اكز البحتيّة لعناوين بحثيّة جديدة.

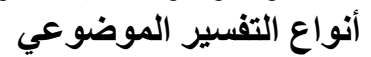

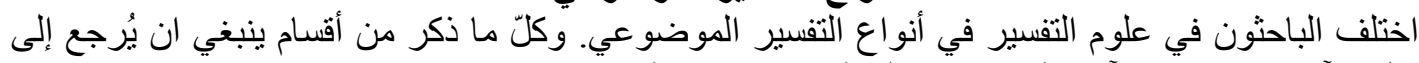

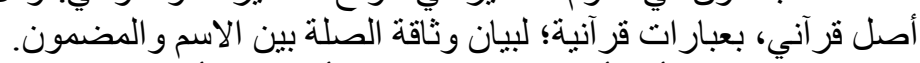

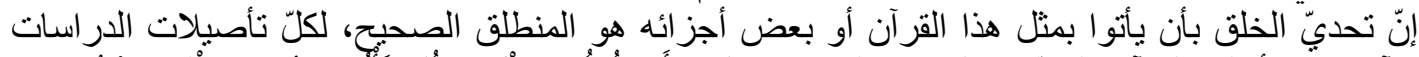

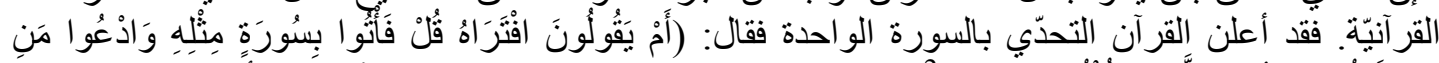

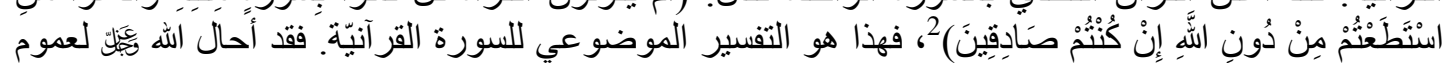

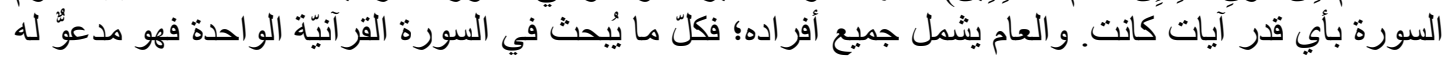

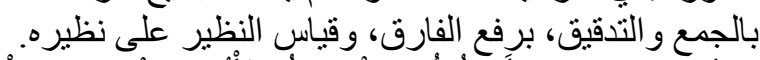

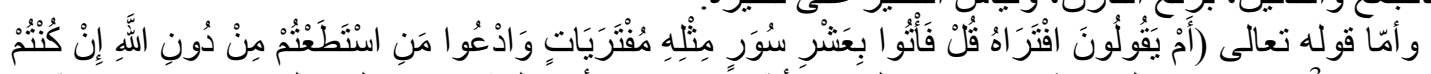

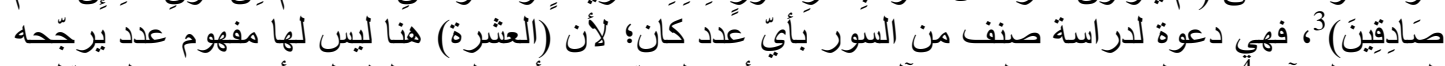

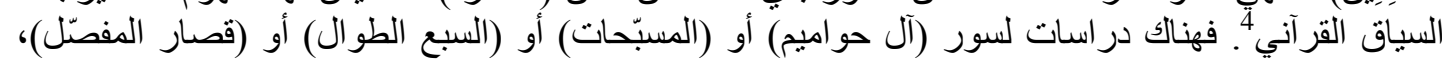

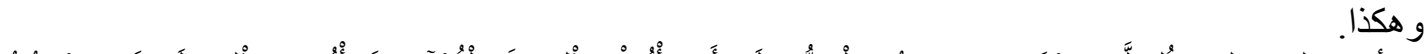

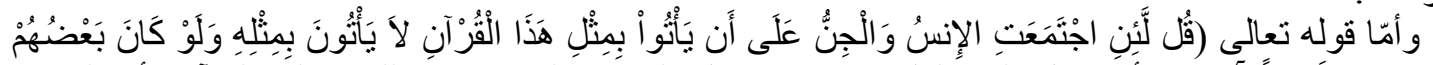

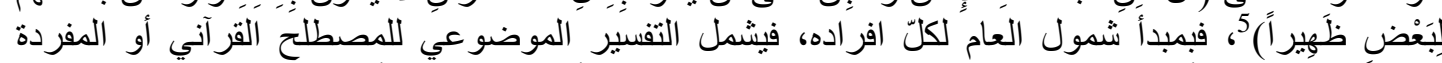

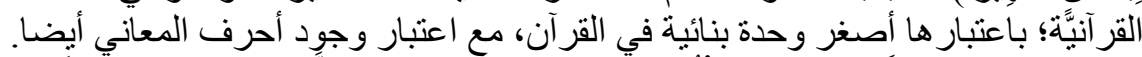

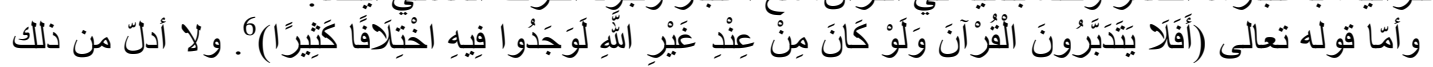

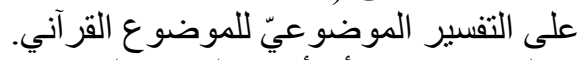

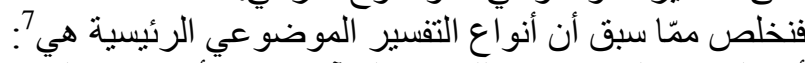

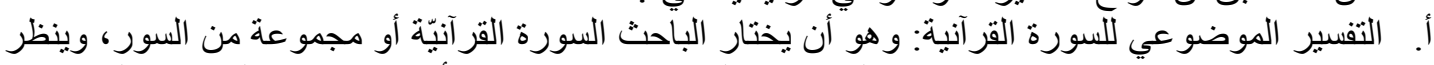

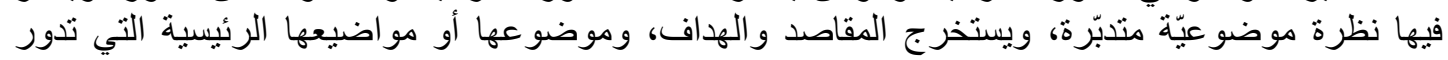
حولها بو حدة موضو عيّة متناسقة.

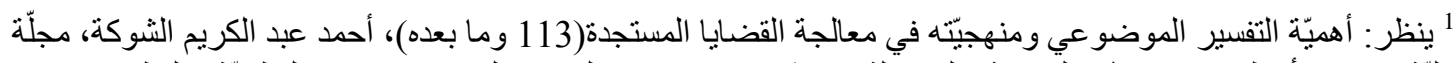

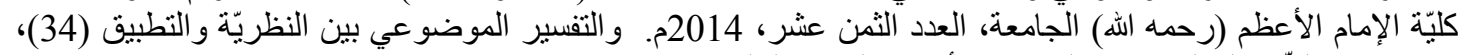
صلاح عبد الفتّاح الخالدي، دار النفائس، الأردن، الطبعة النّنة الثالثة، 2012م.

(38) سورة يونس (38)

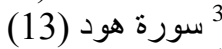

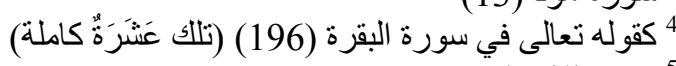

(88) سورة الإسراء فئاء

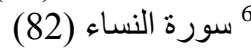

7ينظر: التفسير الموضوعي بين النظريّة و التطبيق (59) 
ب. التفسير الموضوعي للمصطلح القرآني: يختصّ هذا النوع بالمفردات القر آنيّة، إذ يختارها الباحث لأسباب

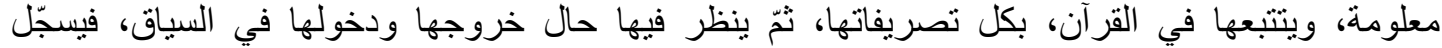
الملاحظات الدقيقة ، ويخرج في بنتائج ولطائف وحقائق مدعمة بالداليل.

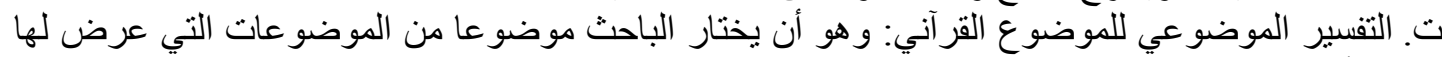

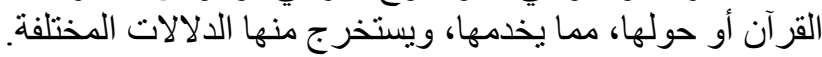

أهم المصنّفات في التفسير الموضوعي

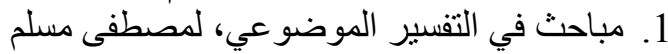

2.

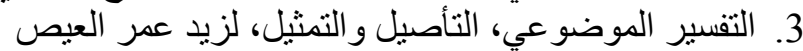

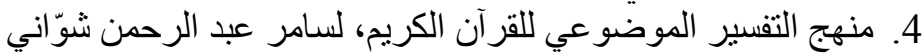

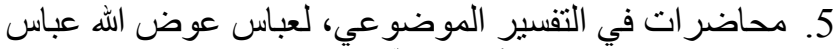

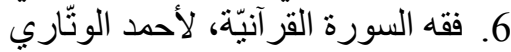

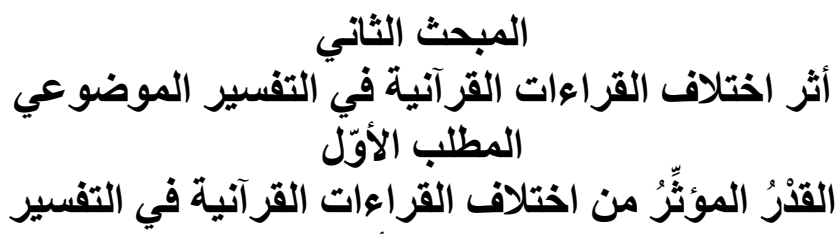

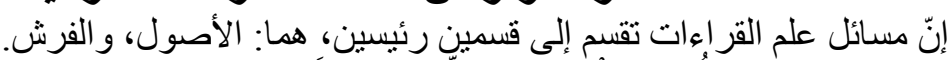

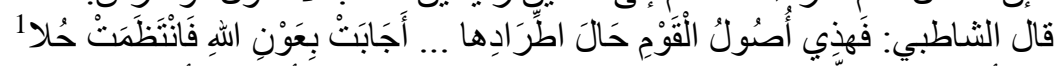

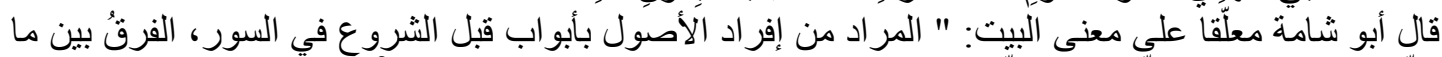

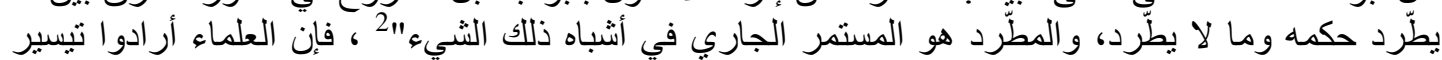

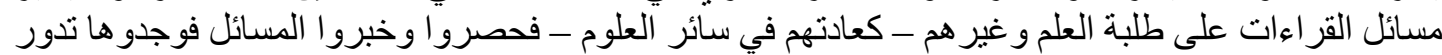

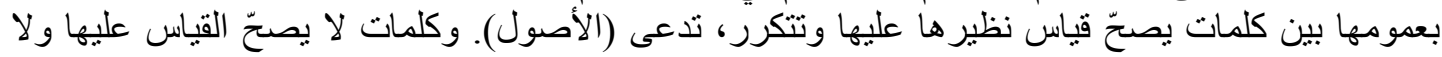
تنكرر، وتدعى (الفرش).

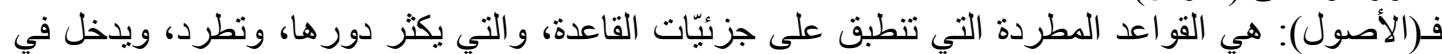

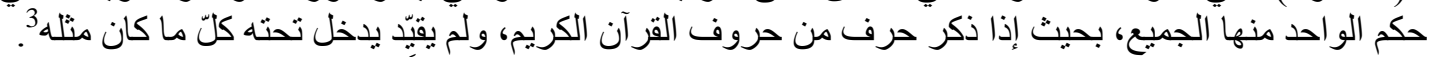

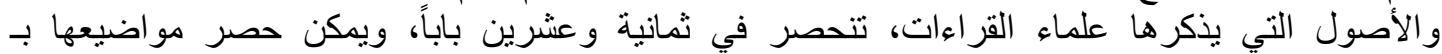

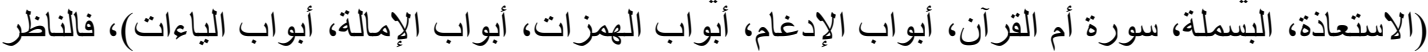

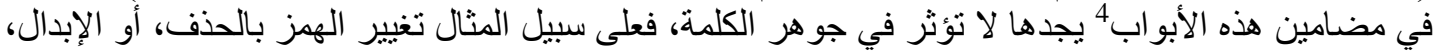

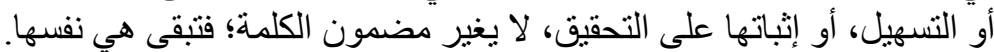

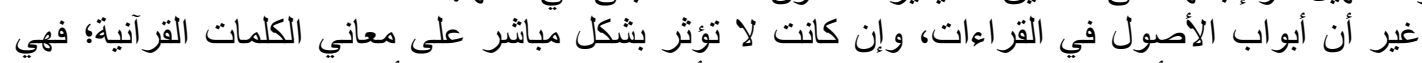

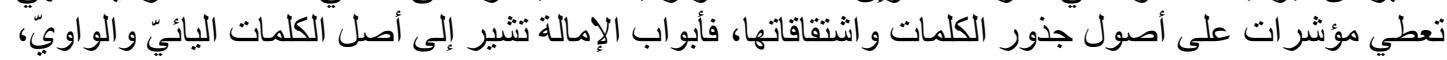

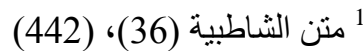

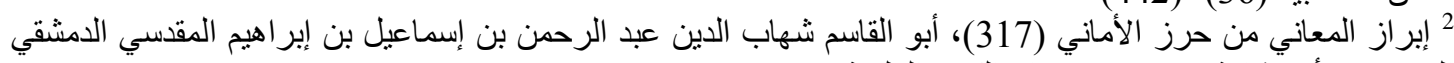

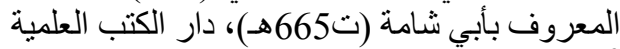

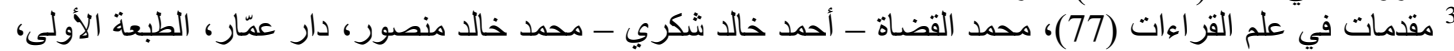
2001 4 ينفرد باب سورة الفاتحة من الأصول كونه يؤثر في معاني الكلمات، كالاختلاف في (ملك) و(مالك). [ينظر: إبراز المعاني من حرز الأماني (70)] 
وكذلك قلب الهمزة واواً أو ياءاً في وقف حمزة وهشام على الهمز ، ومعلوم ما لهذا الأمر من تعلّق بنوع أصيل

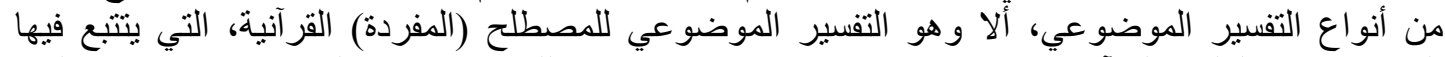
الباحث جذر الكلمة القرآنية واشتقاقاتها وتصريفاتها، وما ينتع ذللك من تغيّر بالمعاني. ففي باب (الفتح

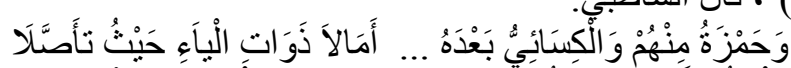

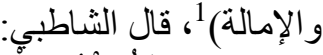

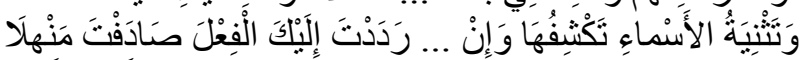

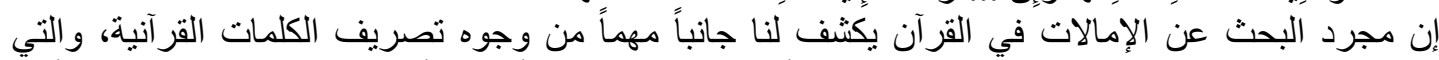

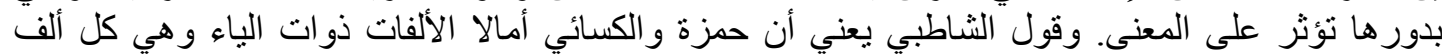

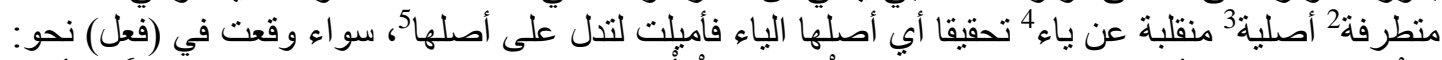

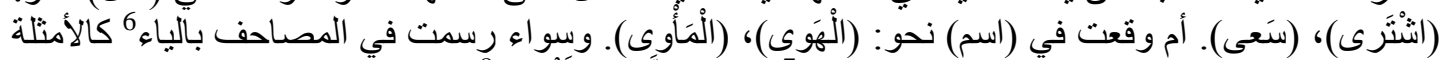

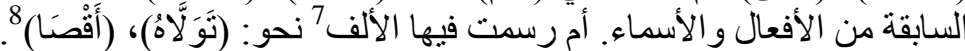

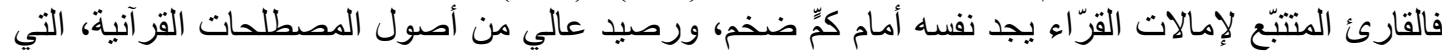

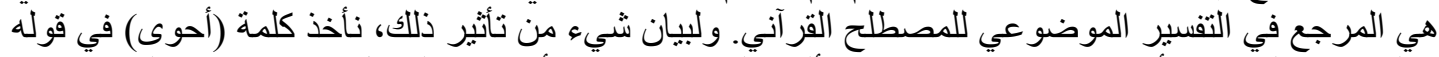

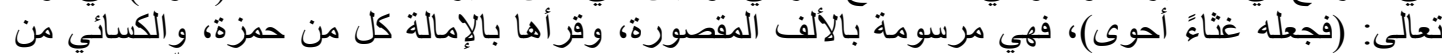

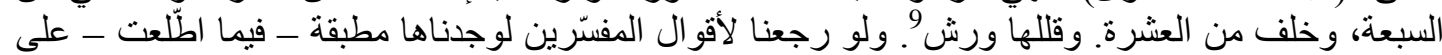

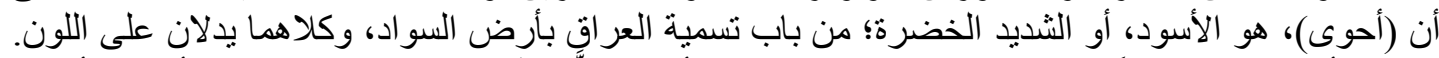

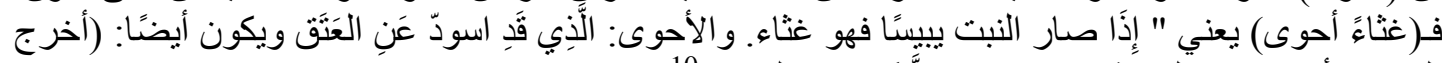

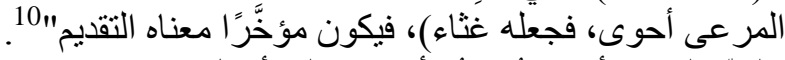

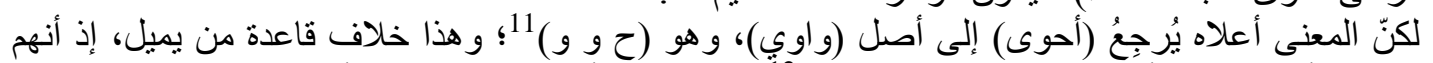

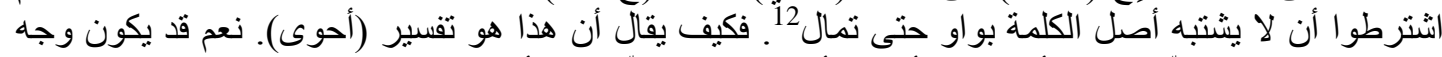

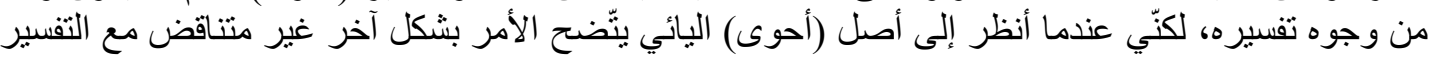

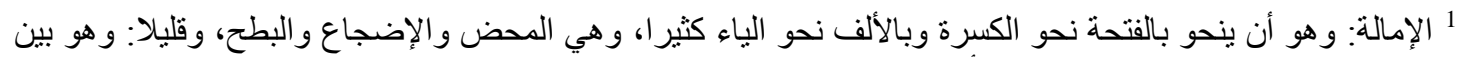

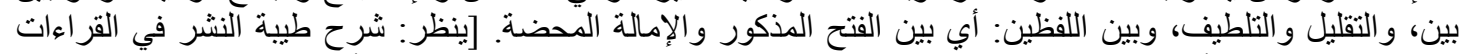
(115)، شمس الدين أبو الخير ابن الجزري، محمد بن محمد بن يوسف والإن (ت833هـ)، ضبطه/ أنس مهرة، دار الكتب العلمية

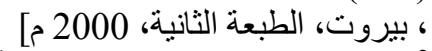
2 احترز عن المتوسطة نحو: وَنَمارِقِقُ، باع، وَسارَ. [ينظر : الو افي في شرح الثُاطبية (140)]

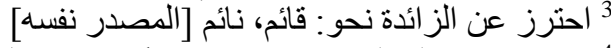

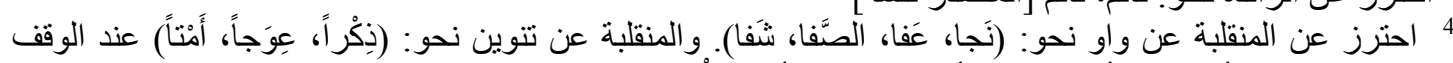

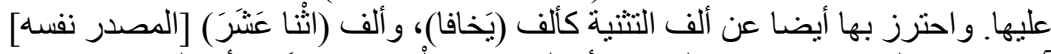

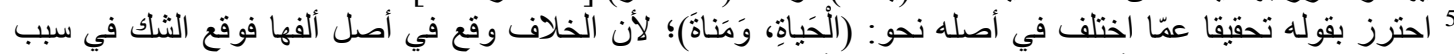

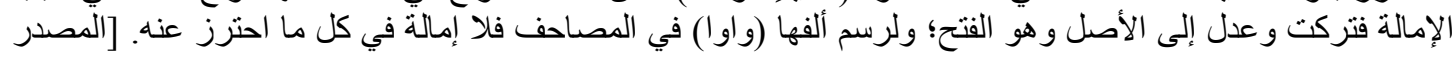

$$
\begin{aligned}
& \text { 6عنس] } \\
& \text { 7 يعني ( } 1 \text { ( ) الألف الخنجريّة }
\end{aligned}
$$

8 بنظر: الو افي في شرح الثناطبية (140)

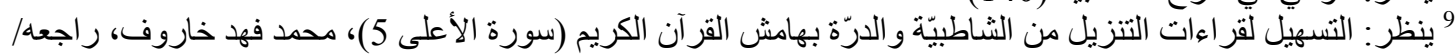

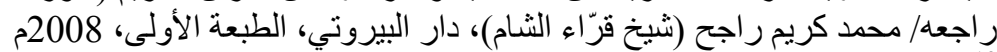

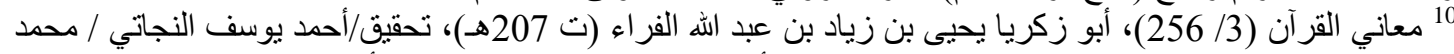

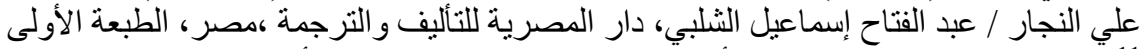

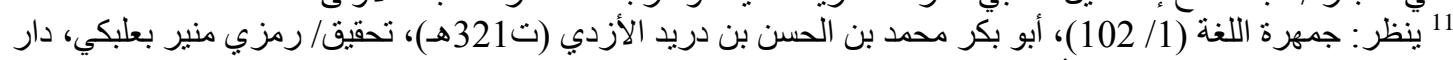

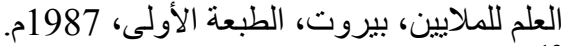
12 ينظر : الو افي في شرح الثناطبية (140) 


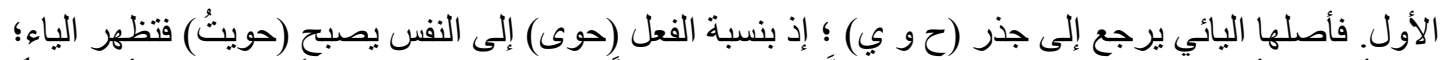

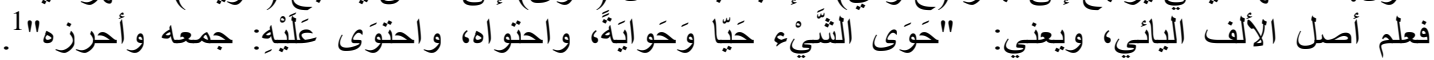

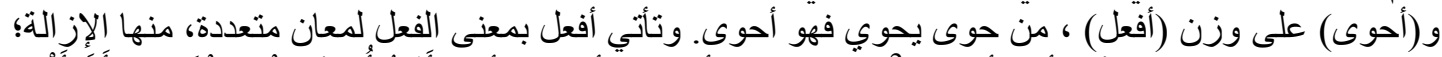

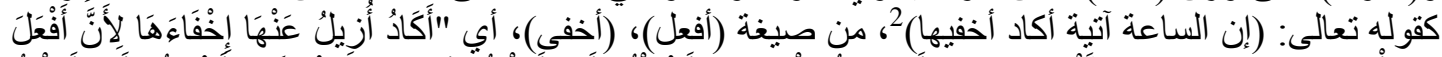

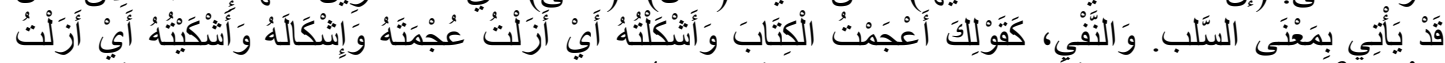

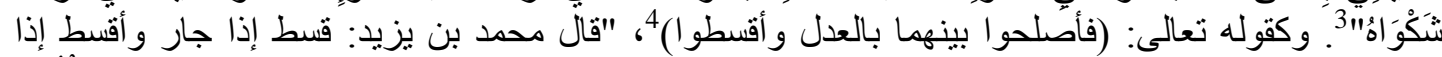

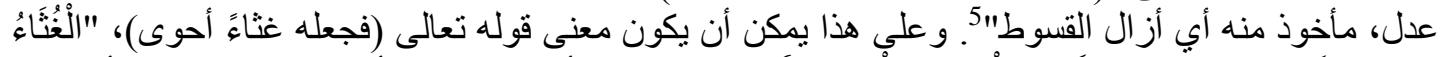

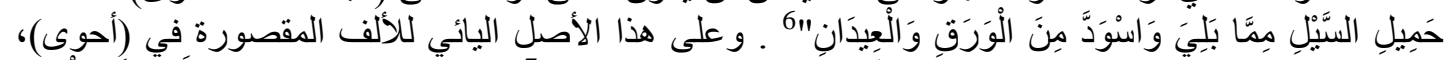

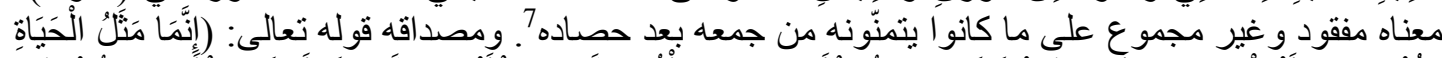

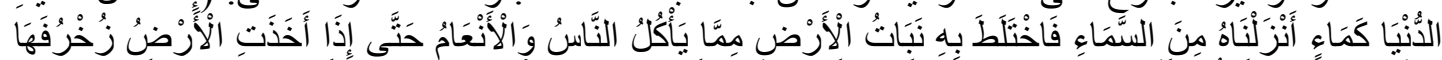

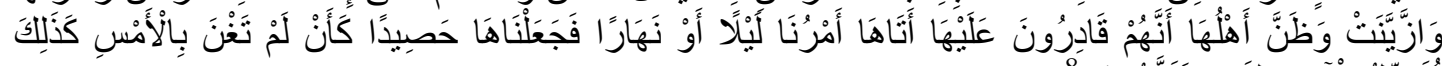

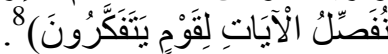

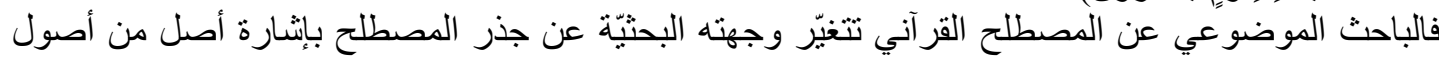

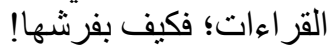

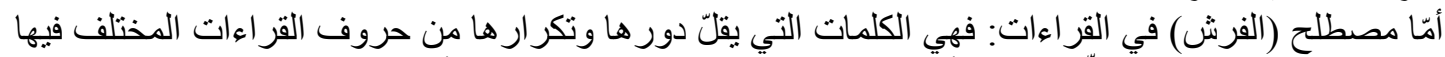

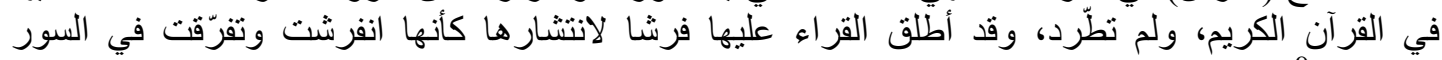

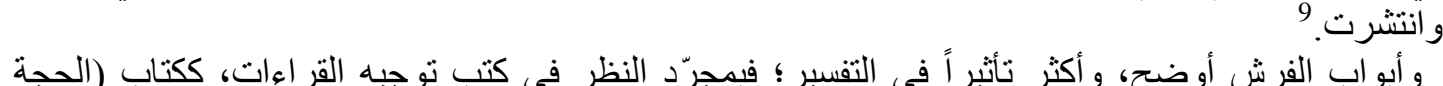

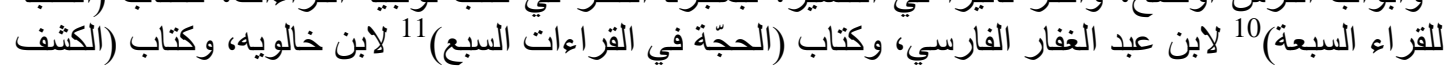

1 المحكم والمحيط الأعظم (4/ 35)، أبو الحسن علي بن إسماعيل بن سيده المرسي (ت458هـ)، تحقيق/ عبد الحميد هنداوي، دار الكتب العلمية، بيروت، الطبعة الأولى، الاعن، على 2000 م.

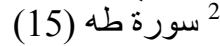

3 مفاتيح الغيب (22/22)، أبو عبد الله محمد بن عمر بن الحسن بن الحسين التيمي الرازي الملقب بفذر الدين الرازي التبري خطيب الري (ت 606هـ)، دار إحياء التراث العربي، بيروت، الطبعة الثالثة ، 1420 هـ

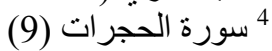

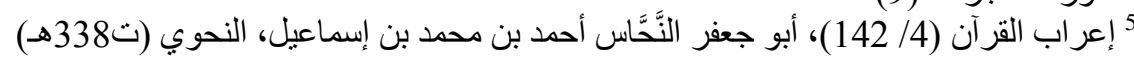

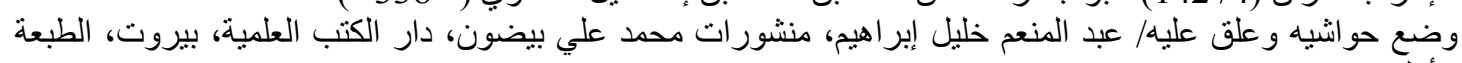

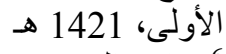

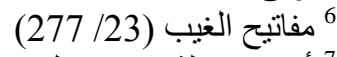

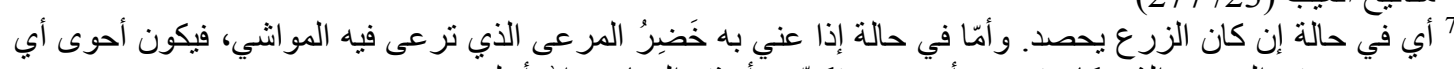

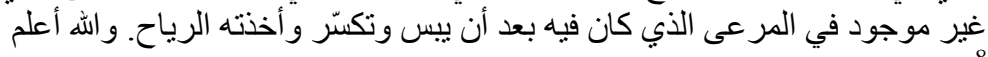

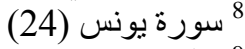

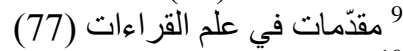

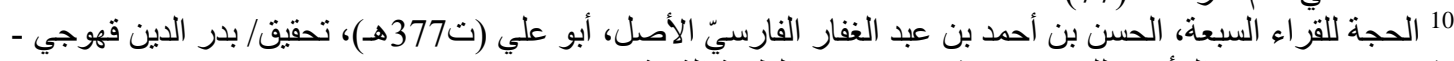

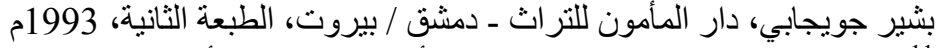

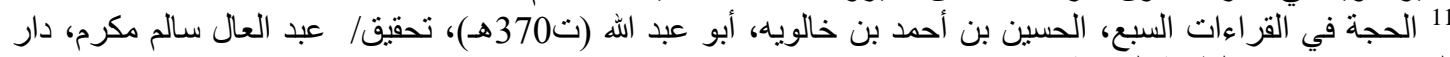
الشروق، بيروت، الطبعة الرابعة، 1401 هـ الته 


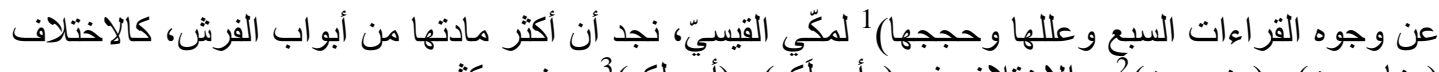

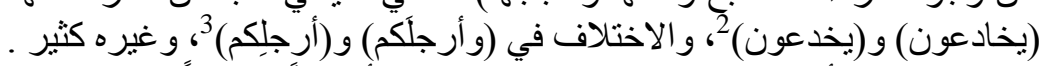

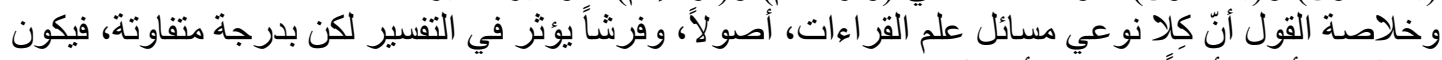
في الفرش أكثر نأثير اً منه في الأصول.

\section{المطلب الثاني}

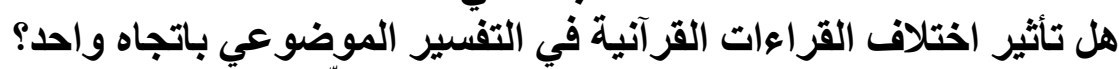

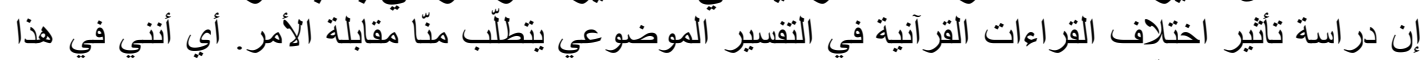

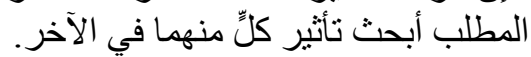

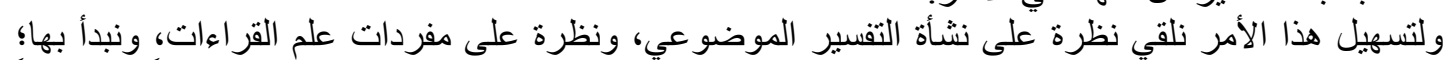

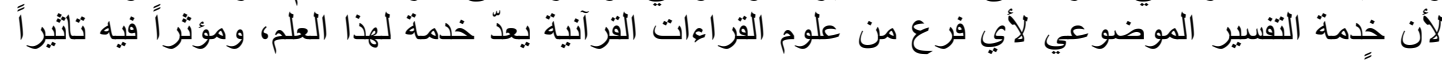

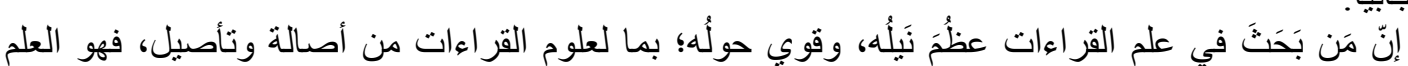

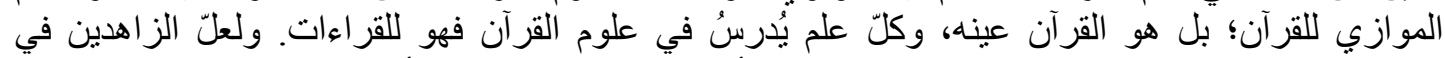

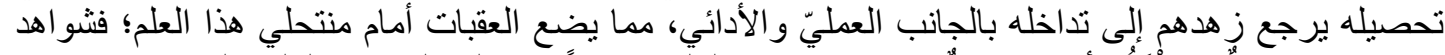

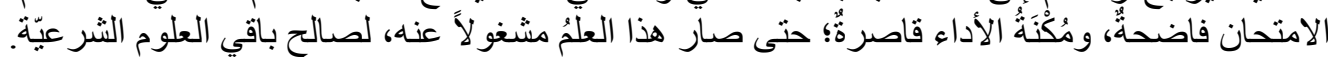

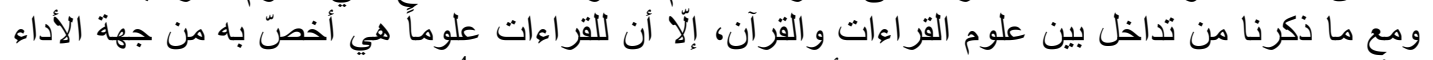

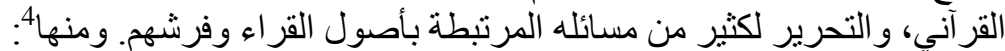

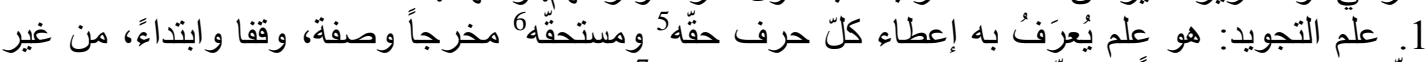

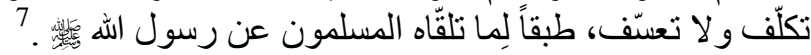

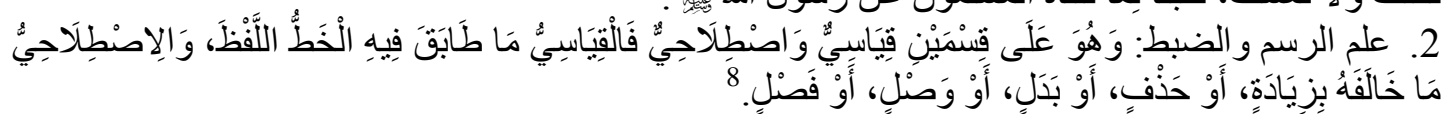

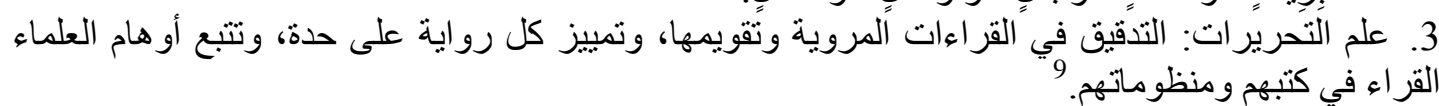

1 الكثف عن وجوه القراءات السبع و عللها وحججها، مكي بن أبي طالب ، أبو محمد القيسيّ (ت437هامها، تحقيق/ محيي

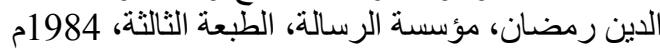

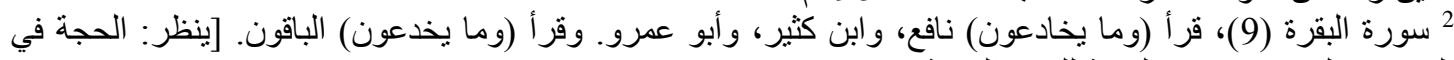

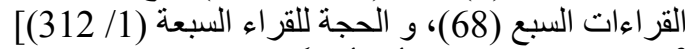

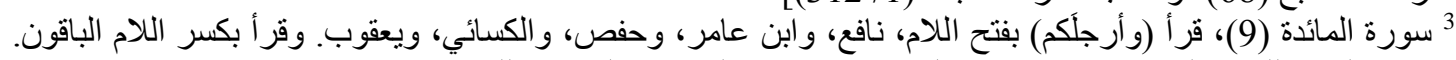

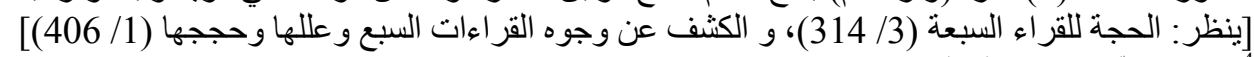

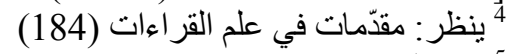

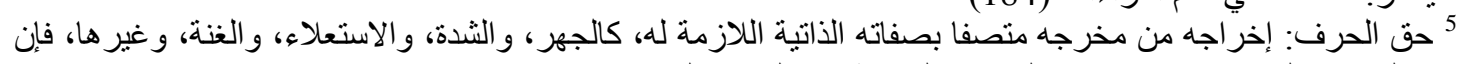

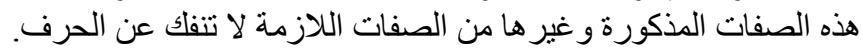

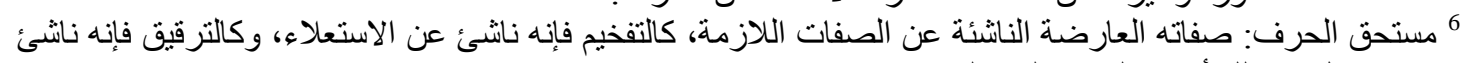

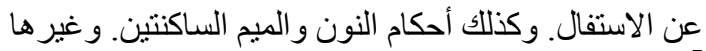

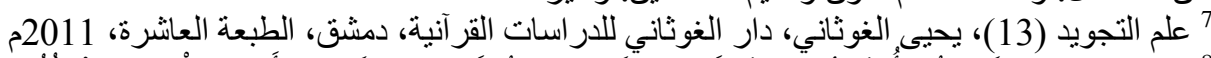

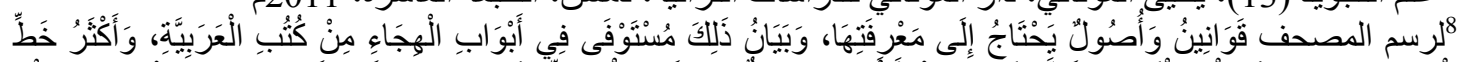

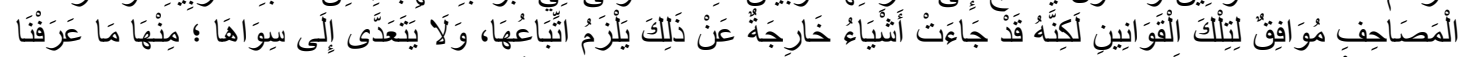

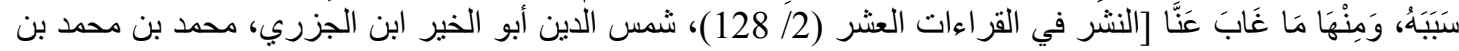

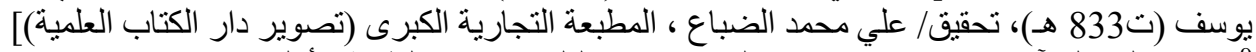

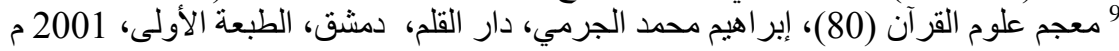




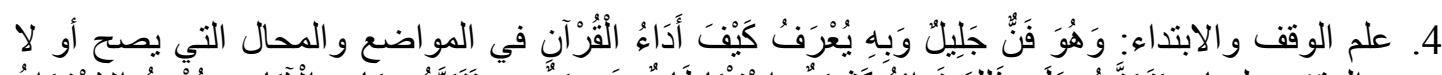

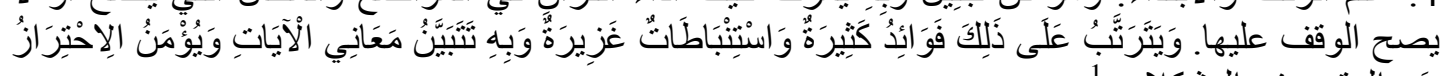
عَن الوقوع في المشكلات.

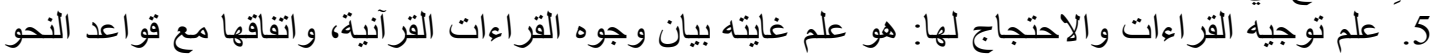

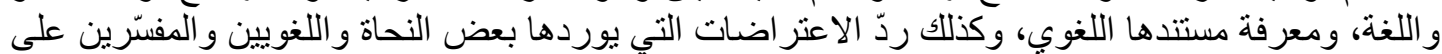
بعض وجوه القر اءات.

6. علم الفو اصل: ويسمى أيضا علم عدّ الآي، وهو فنّ يبحث فيه عن أحوال آيات القرآن، المتضمن معرفة كلّ

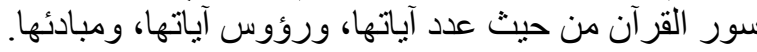

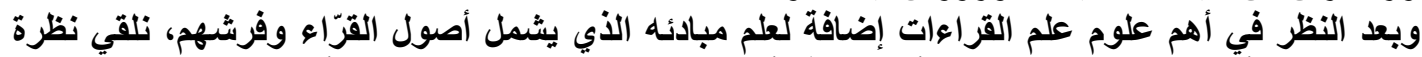

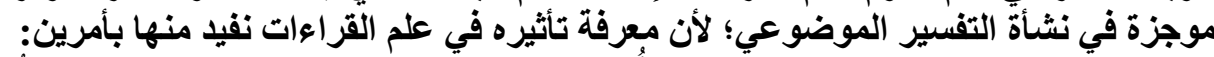

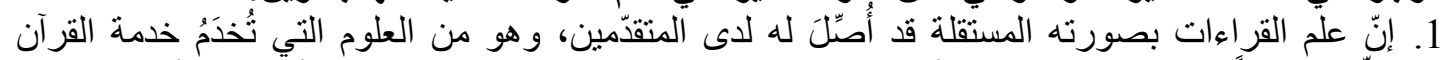

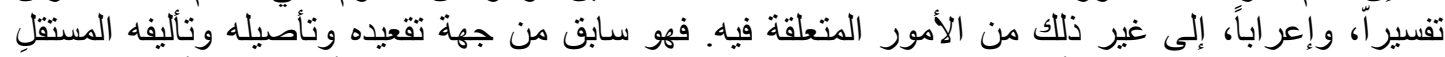

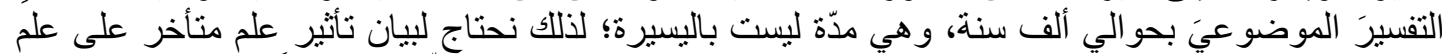

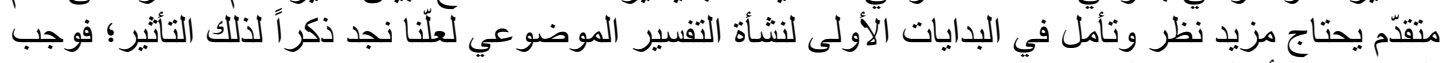

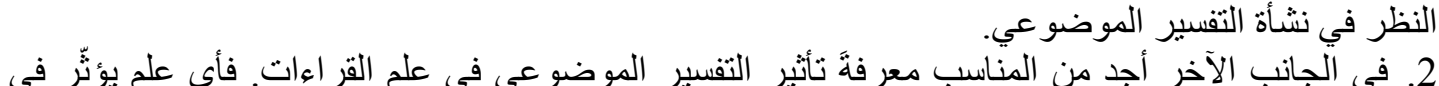

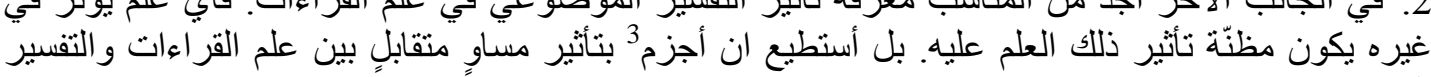
الموضوعي.

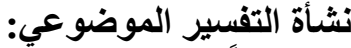
إن علماً بحجم التفسير الموضير الموضو عيّ وريادنه العصريّة، من الصعب أن نحصّل على إجابة شافية لنشأنه كعلم

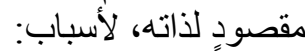
1. إن علم التفسير - الذي هو اللبنة الأساس في بناء التفسير الموضوعي ـ لم تكتمل قو اعد بنائه حتى أواخر

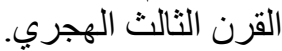
2. كان اشتغال الناس بعلم الحديث رواية ودراية؛ مما صرف كثير الثي من الهمم إليه دون غيره من العلوم.

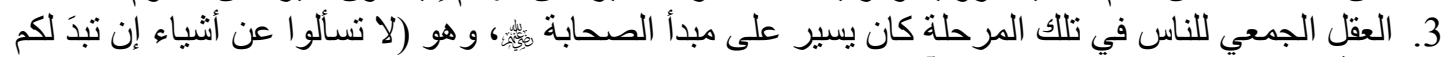

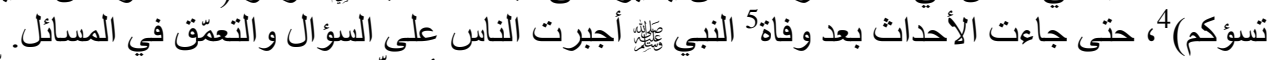

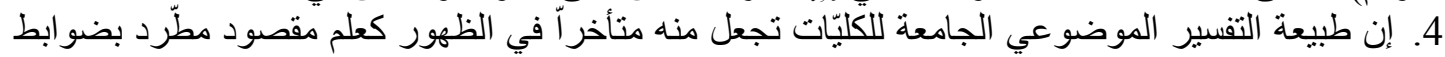
معلومة لعلماء العصر.

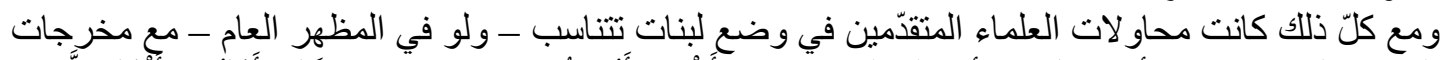

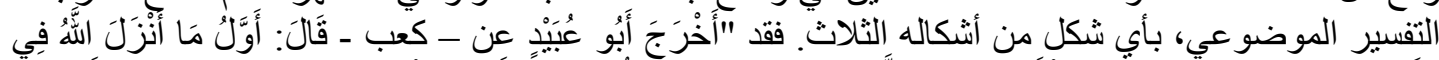

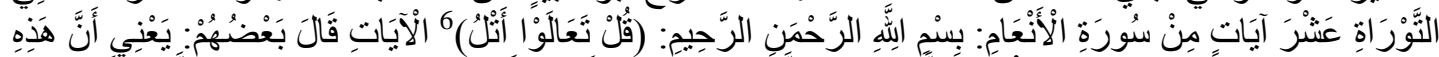

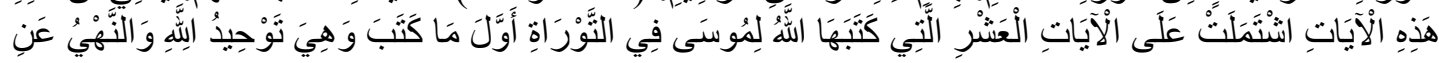

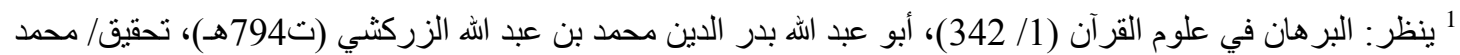
أبو الفضل إبر اهيم، دار إحياء الكتب العربية عيسى البابى الحلبي وشركائه، الطبعة الأولى، النى 1957 م

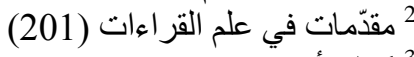

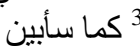
(101) سورة المائدة

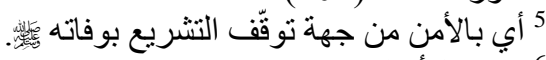

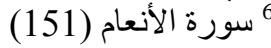




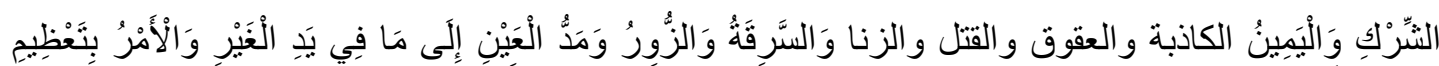

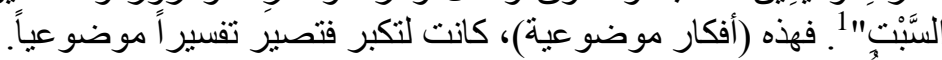

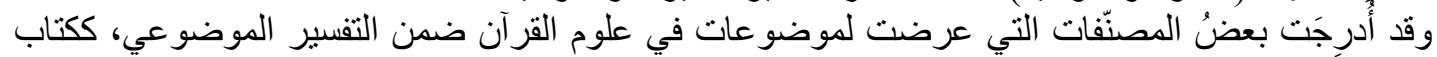

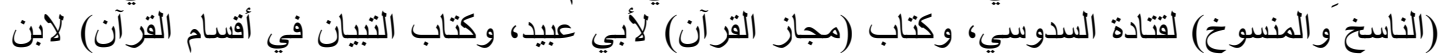

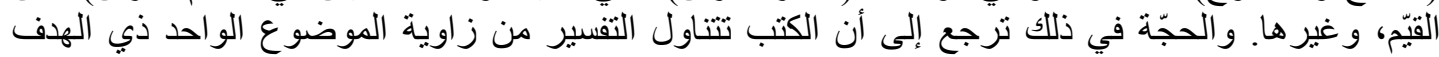

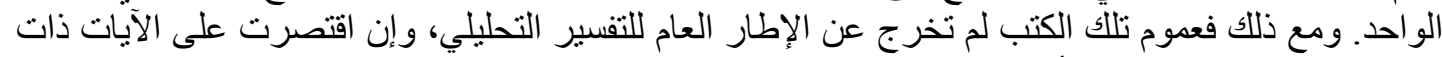

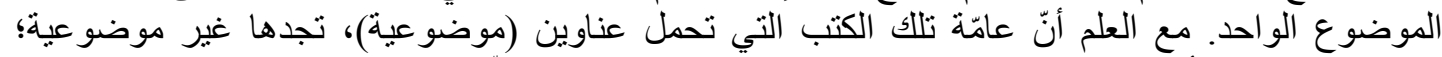

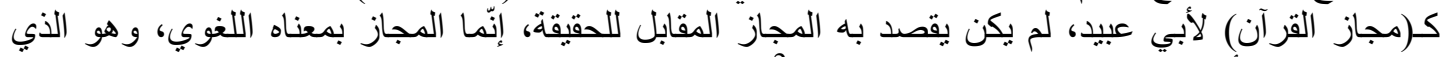

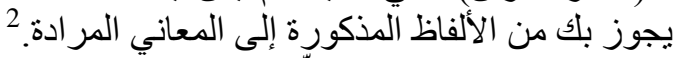

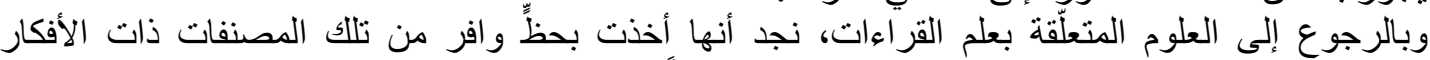

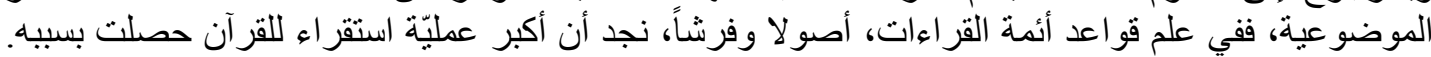

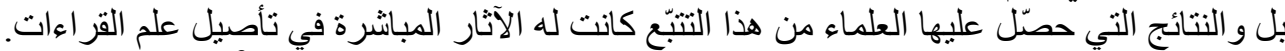

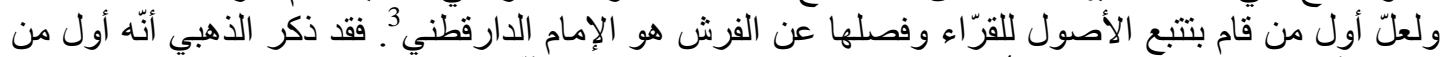

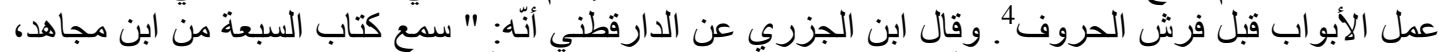

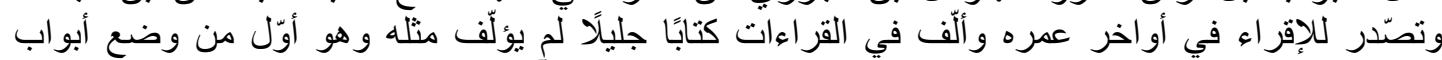

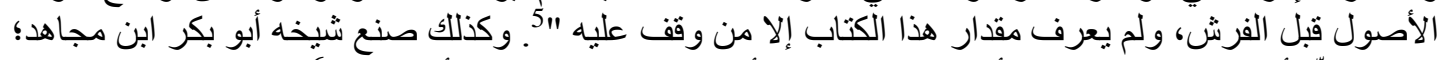

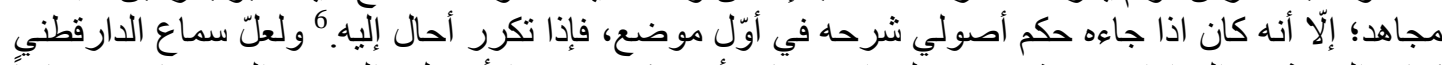

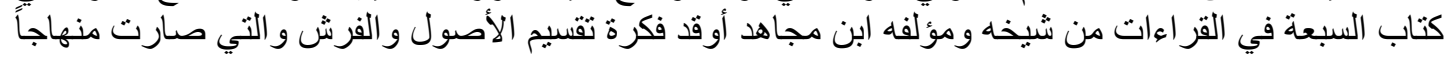

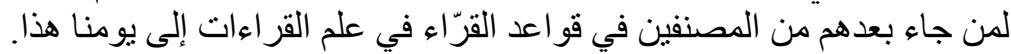

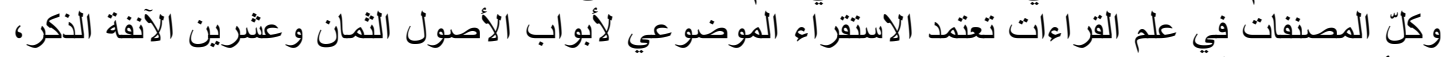

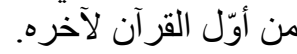

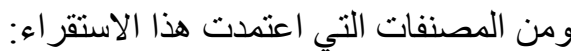

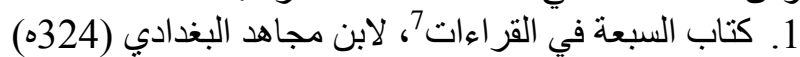

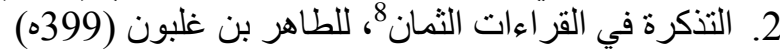

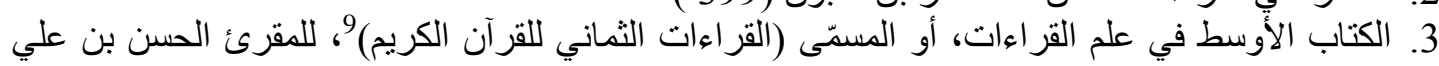

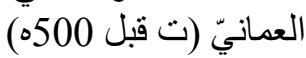

4. كتاب التبصرة في القر اءات السبعَ، لأبي محمد مكّيّ القيسي (437ه)

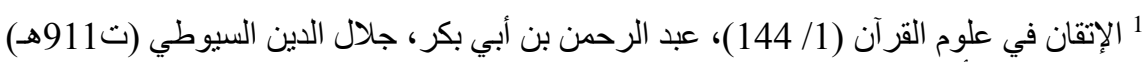

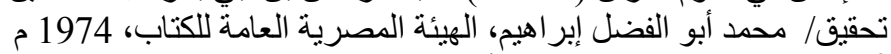

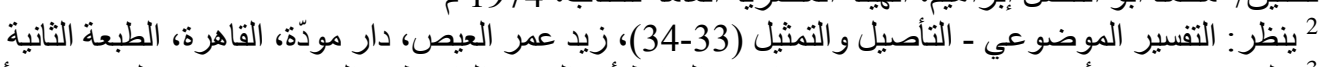

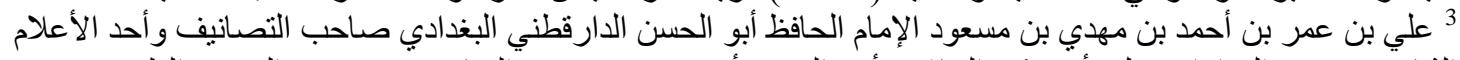

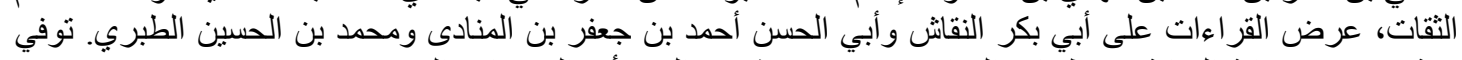

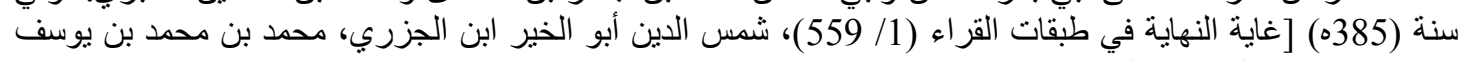
(ت833هـ)، مكتبة ابن تيمية].

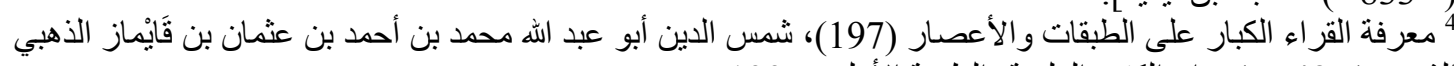

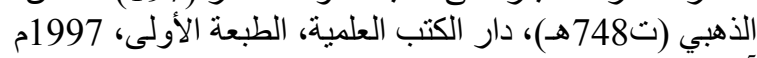

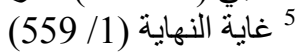
6 ينظر : مباحث في علم القراءات (144)

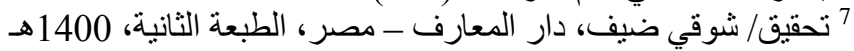

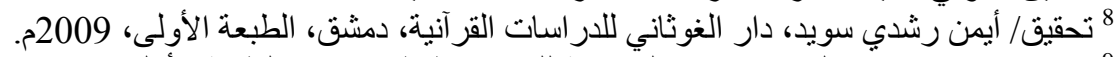
9 تحقيق/ محمد بن عيد الثعباني، دار الصحابة للتراث، طنطا، مصر ، الطبعة الأولى، 2008م الطي، 
5. المستنير في القر اءات العشرّ، لابن سوّار البغدادي الحنفي (496ه)، وقد عبّر عن فرش الحروف بمصطلح 3 (القر اءات)

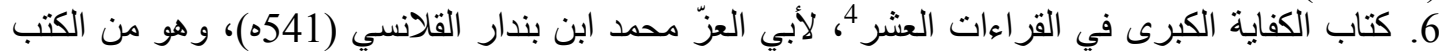

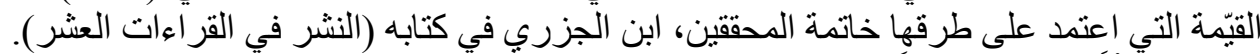

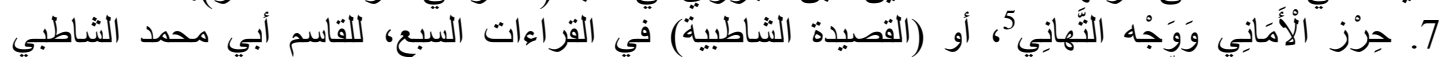

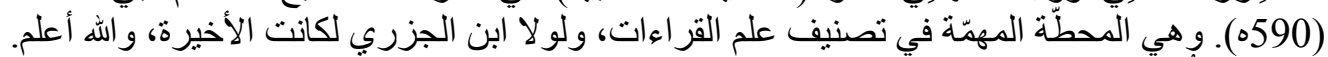

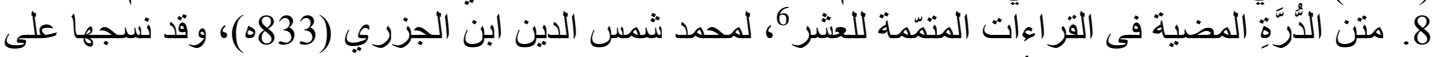

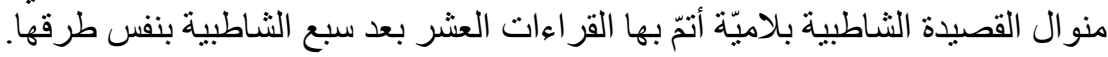

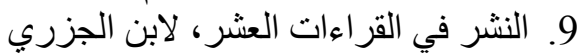

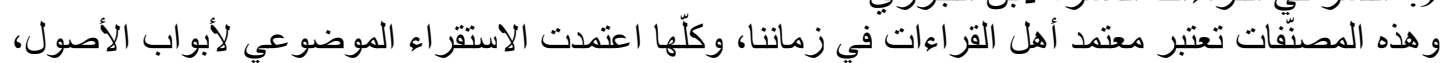

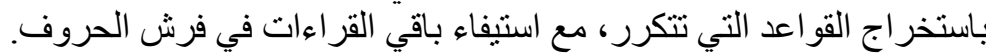

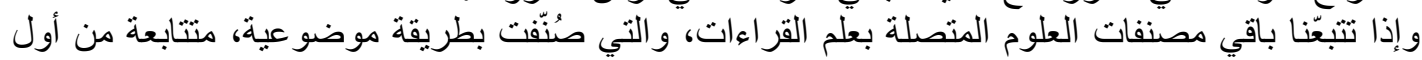
المصحف حتى آخره، فنجدها - على سبيل الاختصار - كالتنالي:

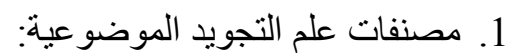

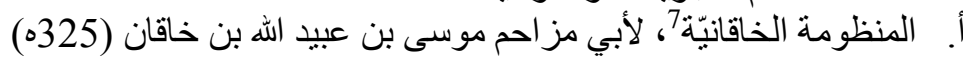

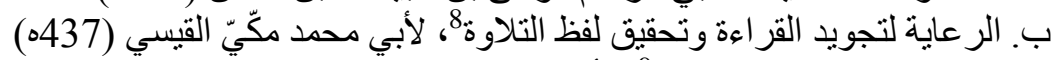

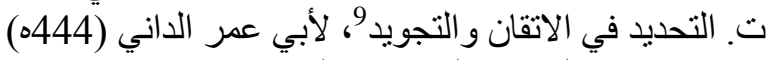

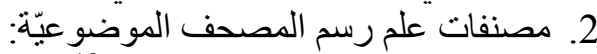

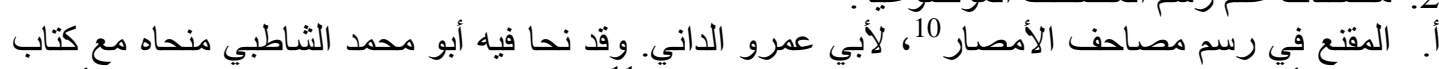

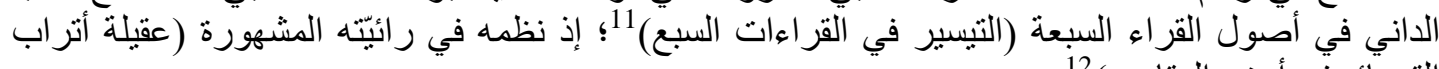

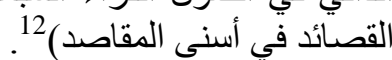
و البحث الموضو لي لئى في هذا الكتاب يتمثّل " بتتبّع الداني لمسائل الرسم ومباحثه، وجعلها في أبواب وفصول

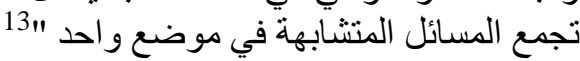

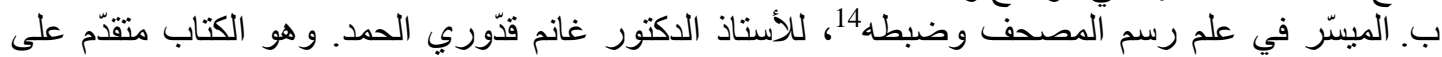

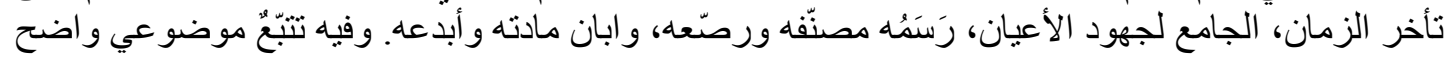

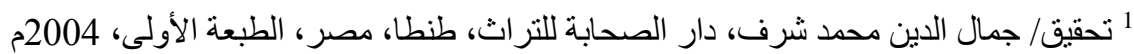
22 تحقيق/ عثمان محمود غز ال، دار الكين الكتب العلميّة، الطبعة الأولى، 2010 2010م.

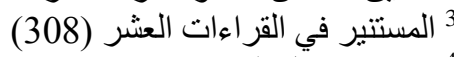

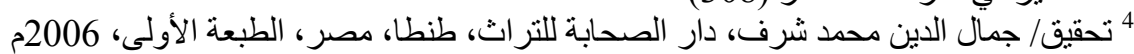

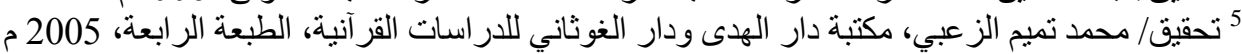

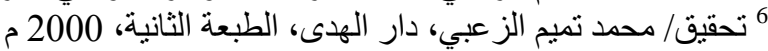

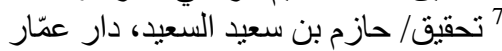

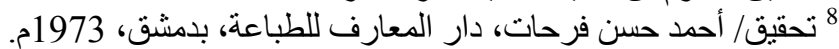

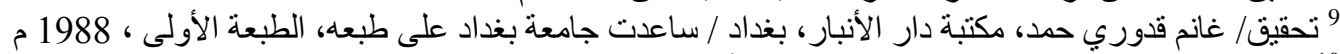

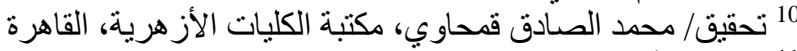
الذي هو أصل القصيدة الثناطبية. 12 تحقيق/ أيمن رشدي سويد، دار نور المكتبات، الطبعة الأولى، 2001م.

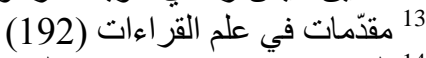
14 الكتاب من إصدار ات مركز الدر اسات و المعلومات القر آنية بمعهد الإمام الثاطبي، طبعة عام 2012م 
يبدأ من الفصل الثالث بـ(خصائص الرسم العثماني) بعد فصلين لا يقلّان أهيّة منه، فيهما ما ليس في غير هما

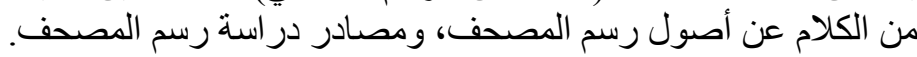
3. مصنفات علم التحرير ات الموضئ الموضو عيّة:

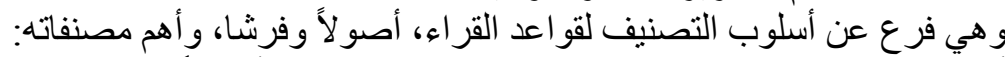

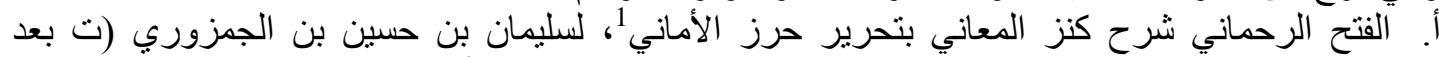

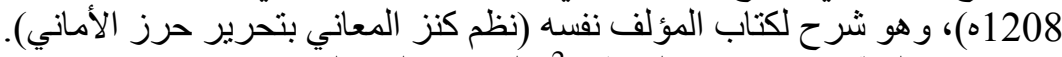

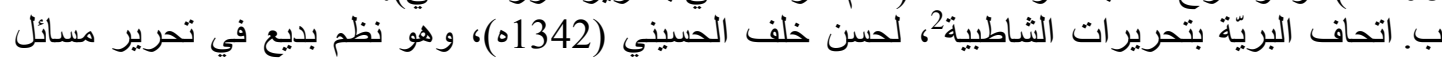

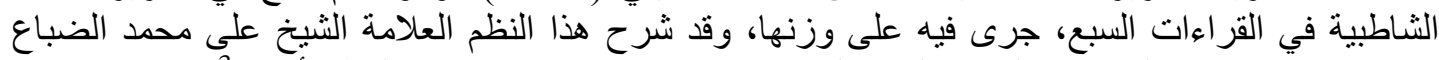

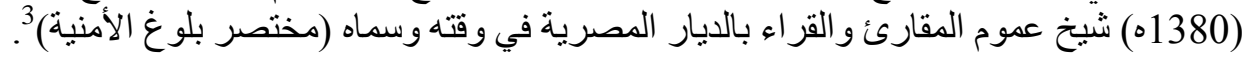

نلاحظ في كتب التحرير ات ما يلي:

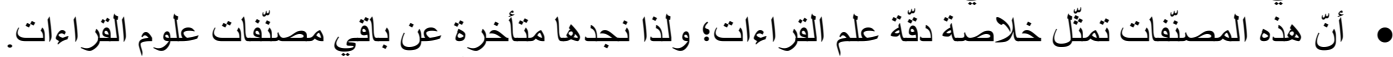

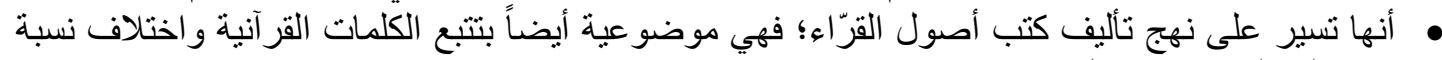
قر اءتها على التحقيق عند كلّ قارئ.

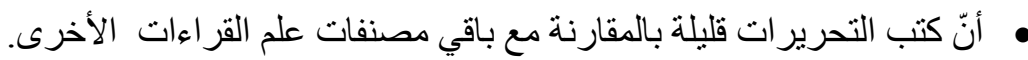

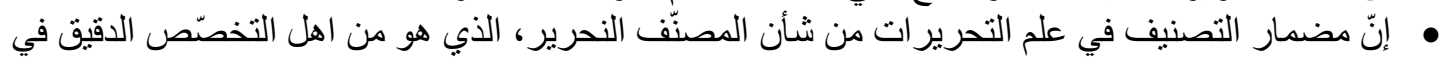
هذا العلم.

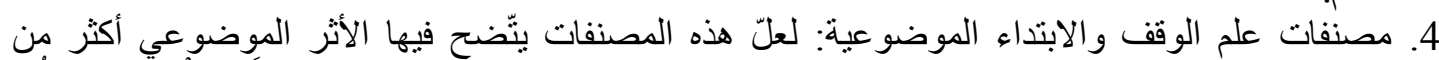

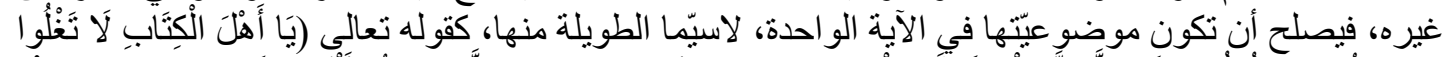

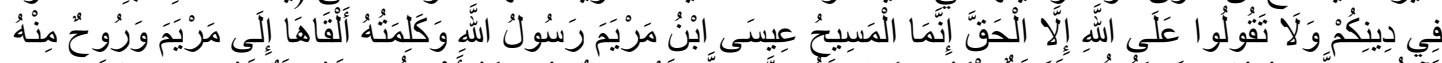

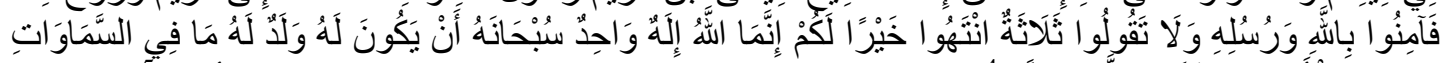

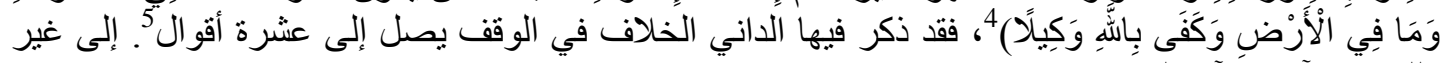

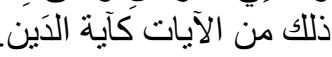

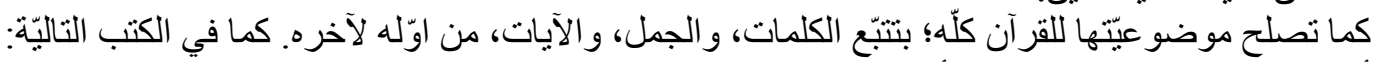

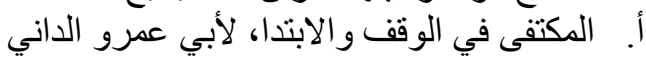

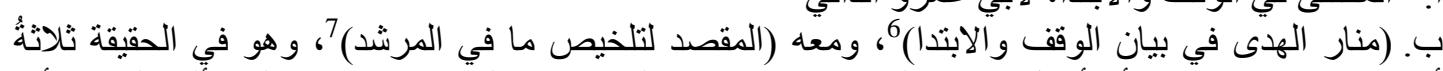

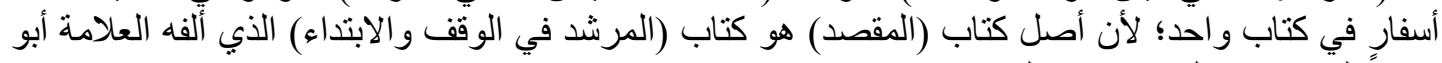

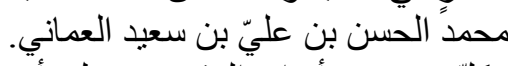

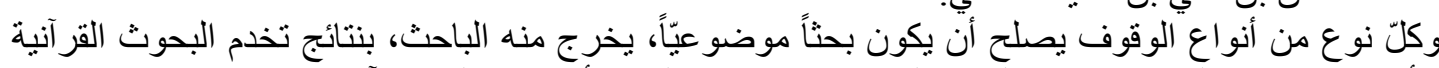

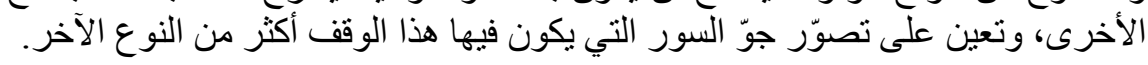

1 تحقيق/ عبد الرزاق بن علي بن ابراهيم موسى، دار ابن القيّم (الرياض)- دار ابن عفّان (القاهرة)، الطبعة الثالثة، 2005م. 22 الكتاب من إصدار دار الصحابة للتراث، طنطا، مصر ، طبعة 2003م.

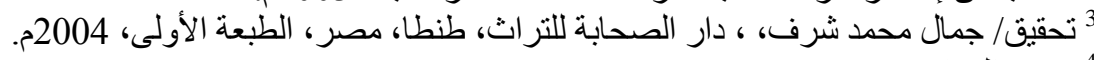
(171) سورة النساء 5 المكتفى في الوقف والابتدا (57)، عثمان (171) عند سعيد بن عثمان بن عمر أبو عمرو الداني (ت444هـ)، تحقيق/ محيي الدين

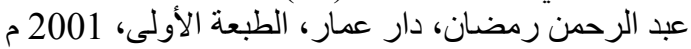

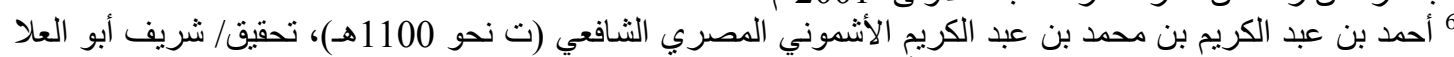

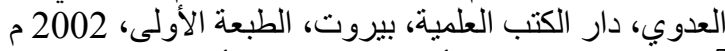

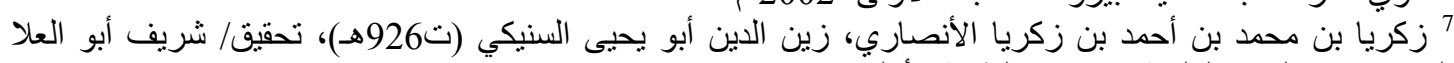
العدوي، دار الكتب العلية، بيروت، الطبعة الأولى، 2002 م 
وقد اعتنى علماء الوقف و الابتداء بالوقف الاختباري - فهو المقصود بهذا العلم - فمنهم من جعل مر اتبه ثمانية:

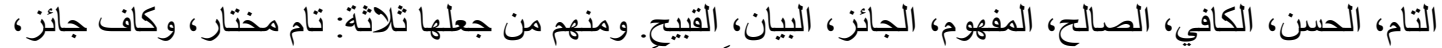

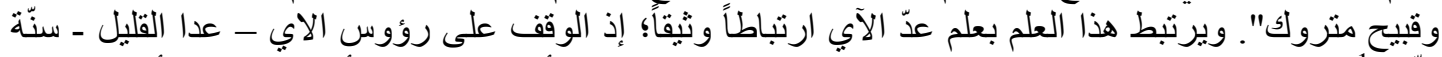

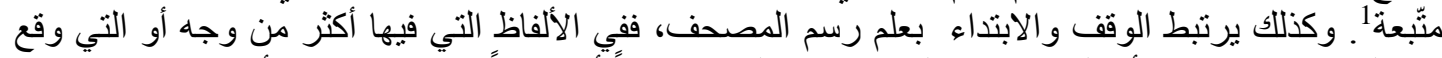

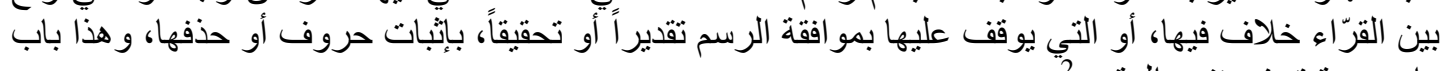

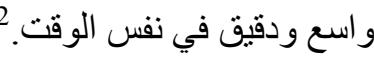

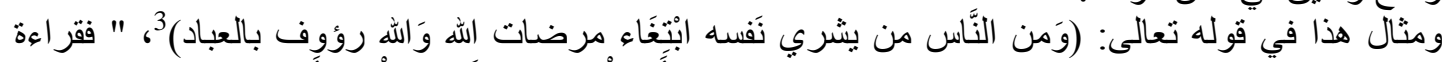

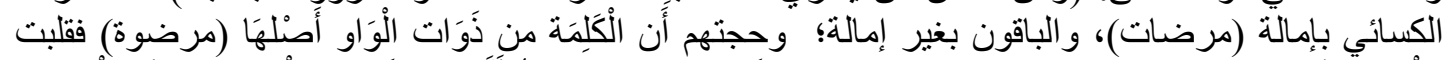

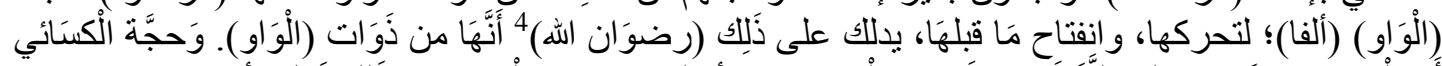

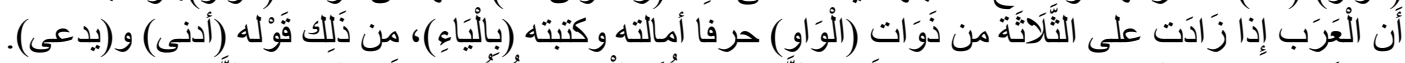

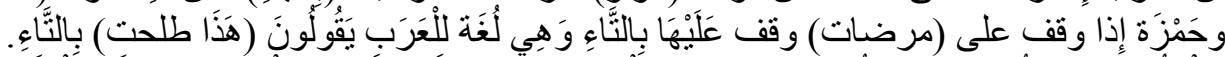

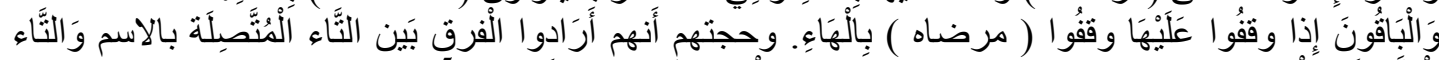

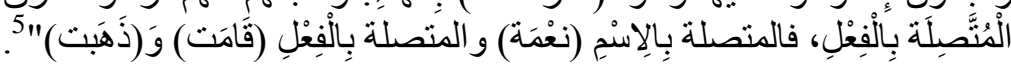

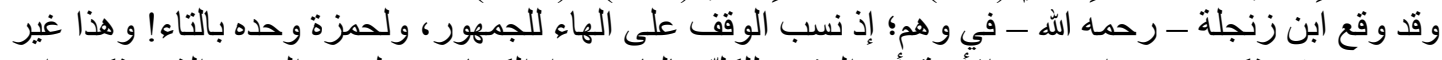

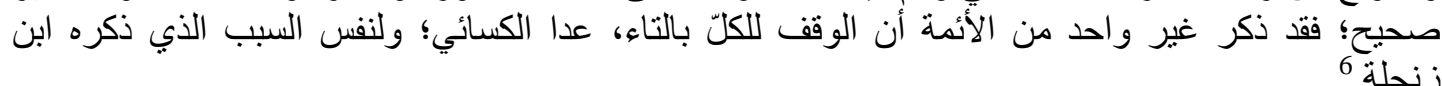

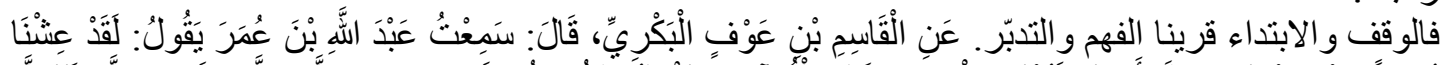

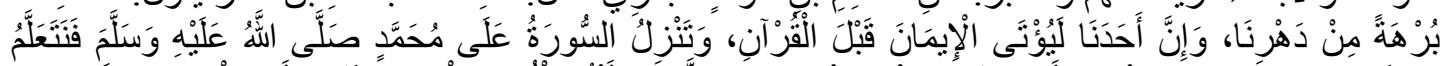

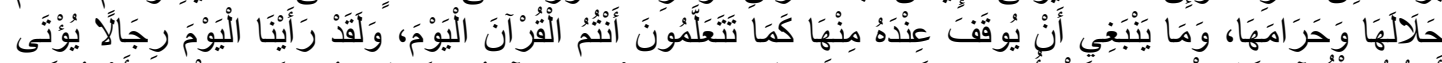

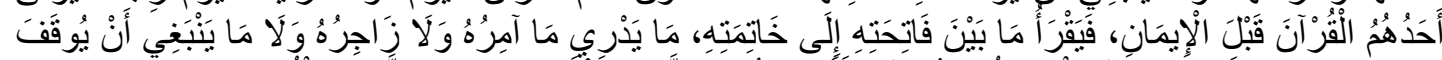

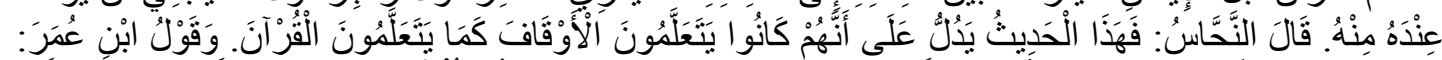

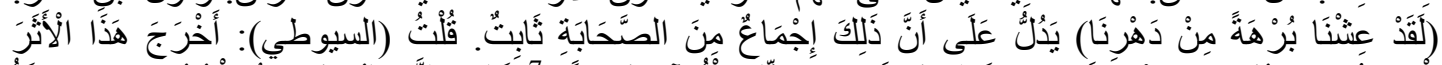

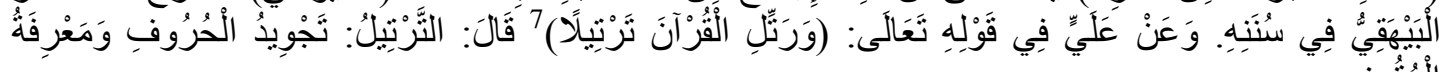

5. مصنفات علم توجيه القراءات و الاحتجاج لها، الموضو عيّة:

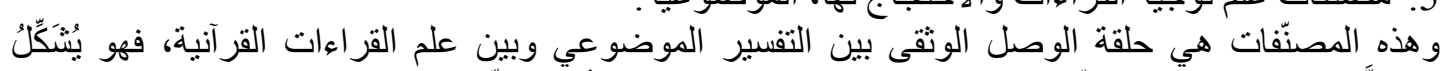

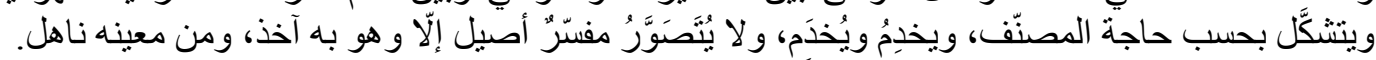

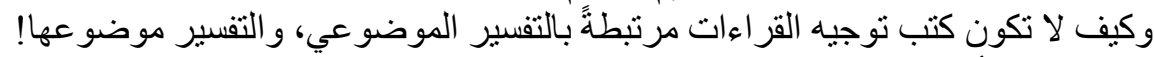

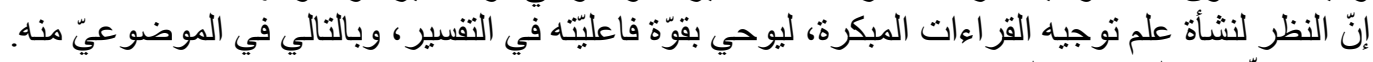

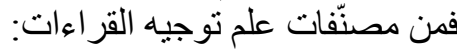

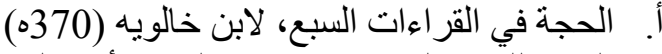

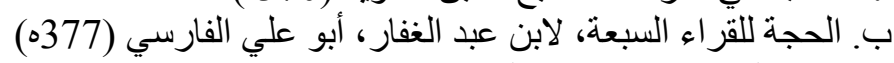
ت. حجة القراءات، لابن زنجلة (403ه)

1 المكتفى في الوقف و الابتدا (8)

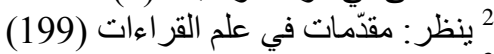
سورة البقرة (207). (174) سورة آل عمر البزة (207) 5 حجة القراءات لابن زنجلة آلة (129) 6 ينظر: النشر في القراءات العشر (144)

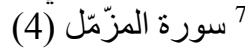




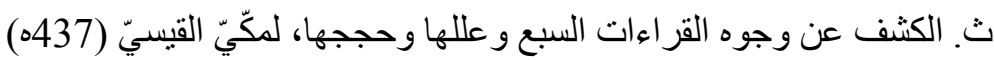

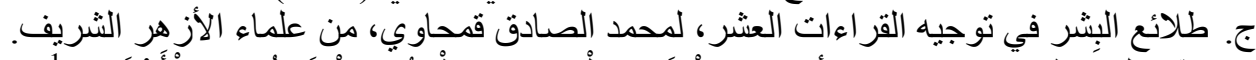

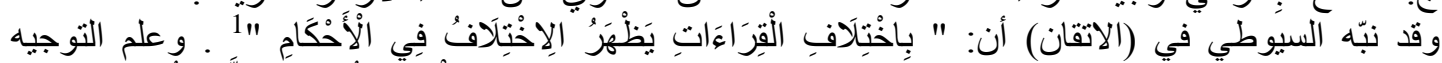

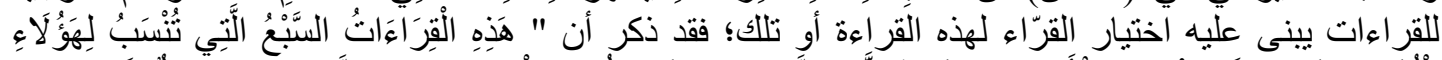

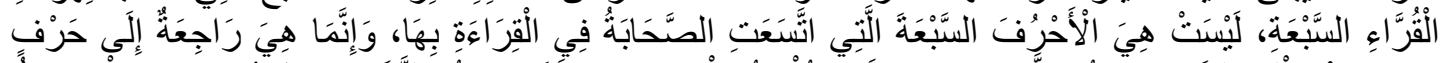

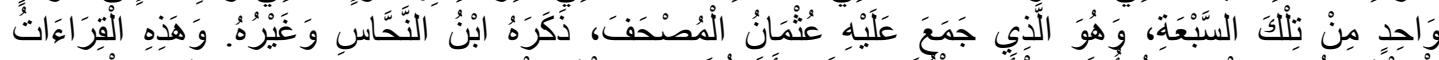

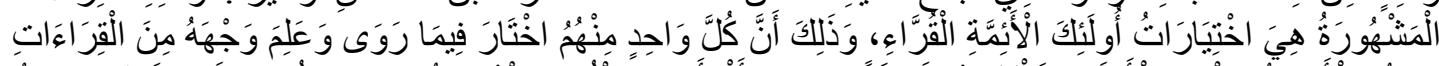

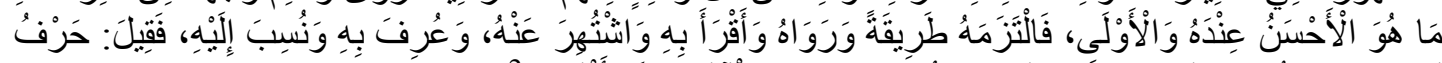

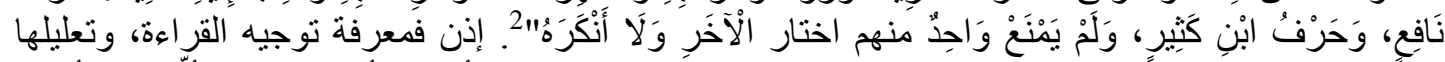

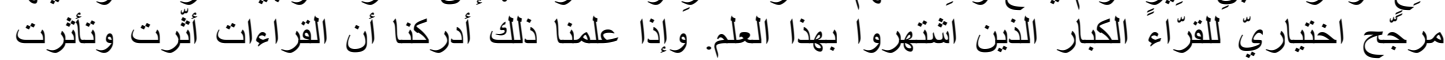

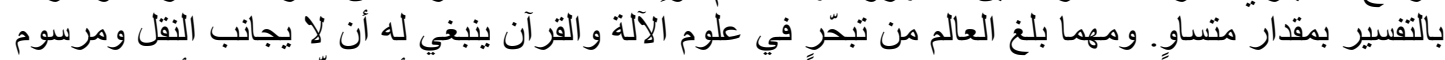

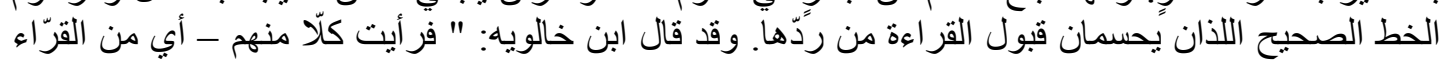

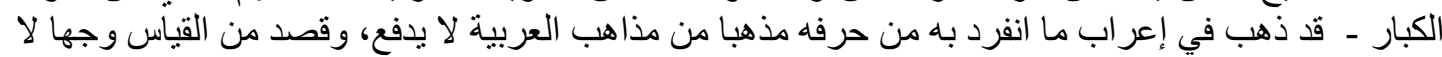

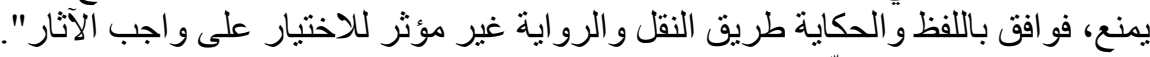

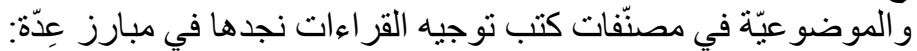

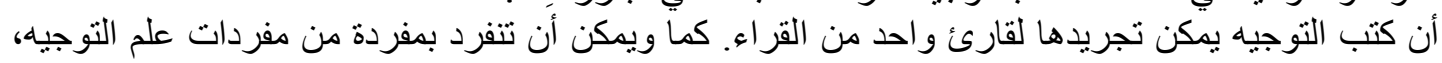

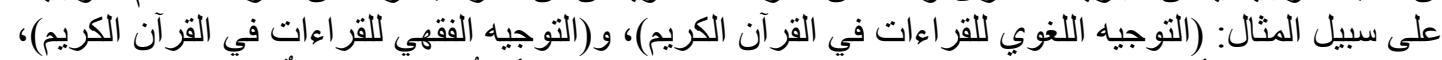

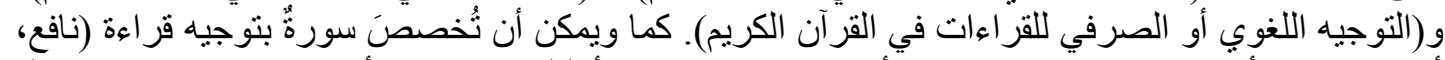

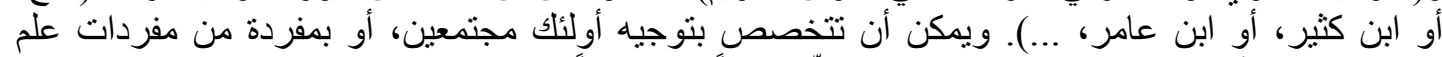

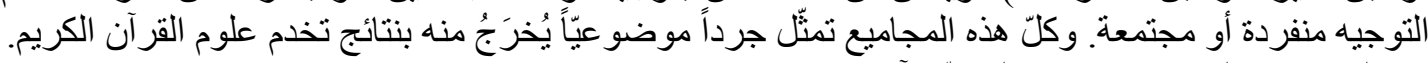

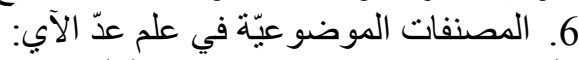

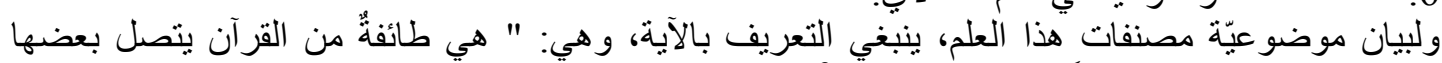

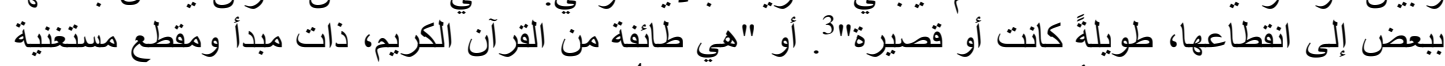

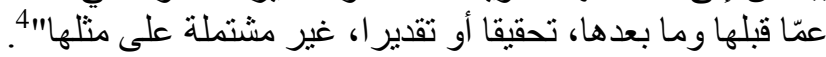

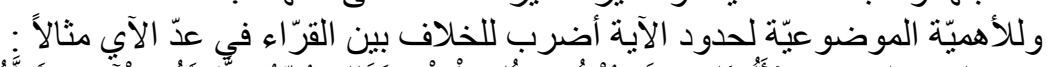

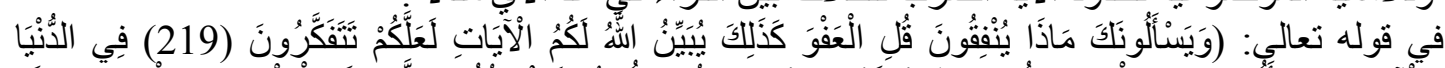

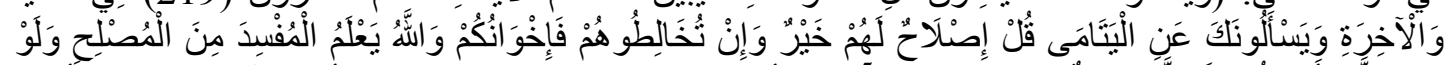

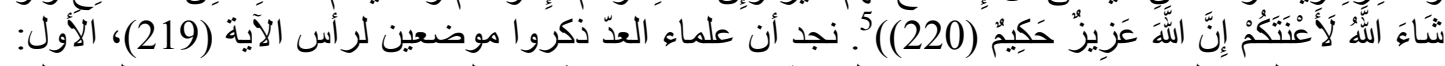

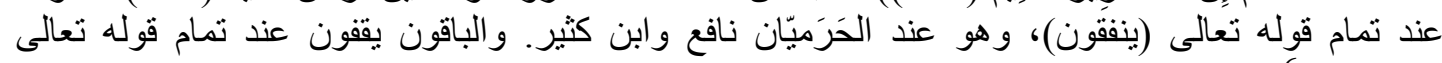
6 (تتفكرون) فنخلص إلى مقطعين يمكن البدء بهما: (قل العفو) عند الحرميّان و(في الدنيا والآخرة) عند الباقين. وبالتحليل

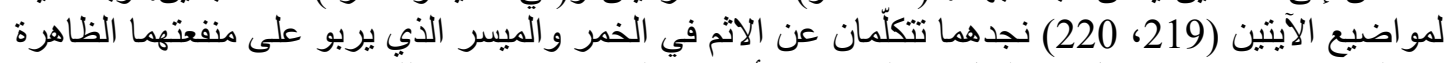

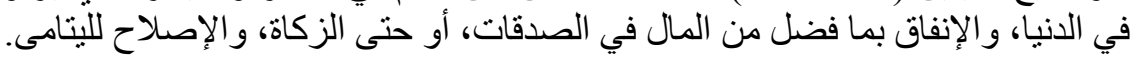

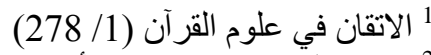

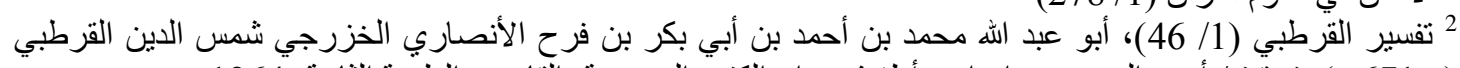

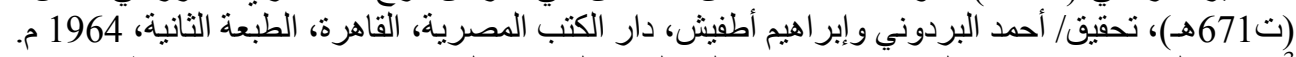

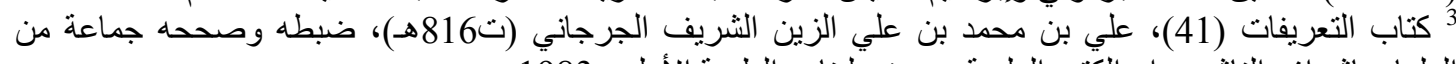

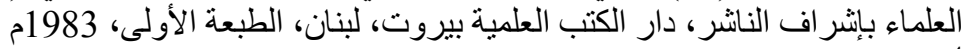

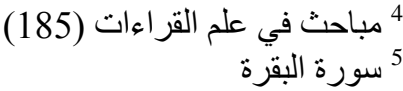
6 (34) 


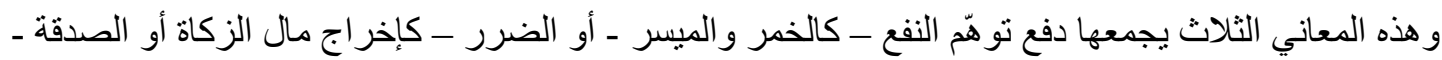

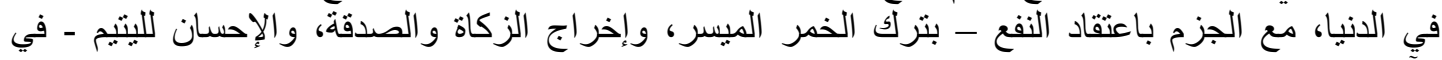

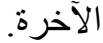

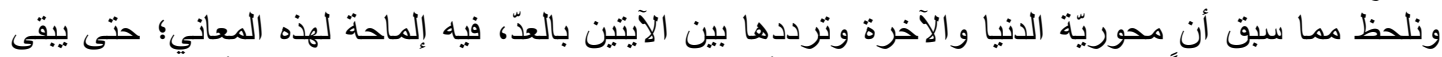

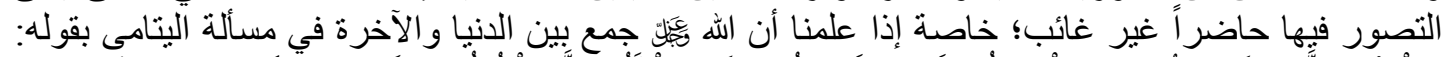

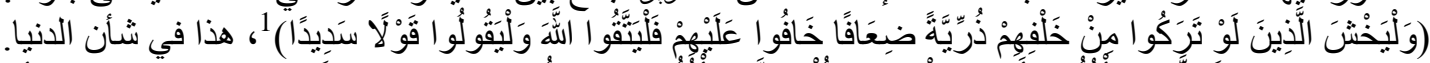

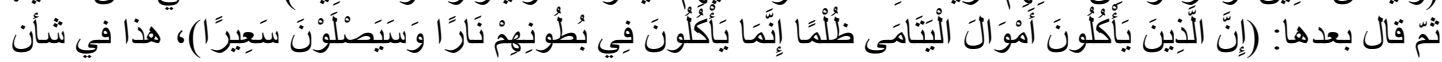

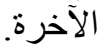

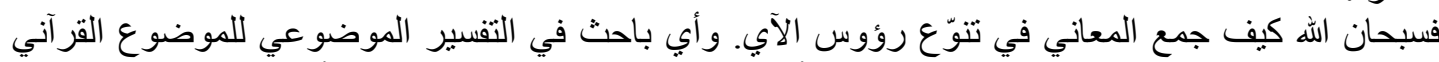

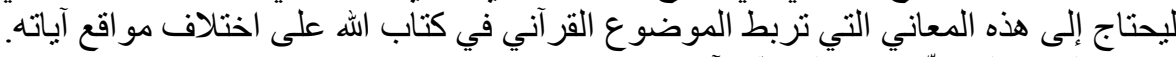

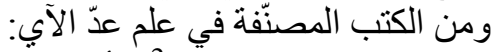

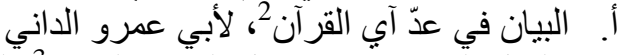

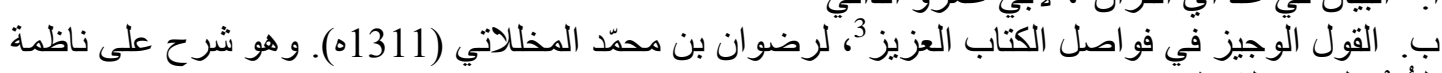
الزُْْرِ للإِمام الشاطبي.

\section{المطلب الثالث

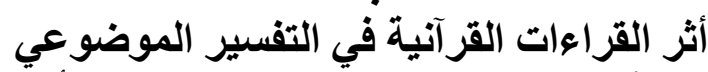

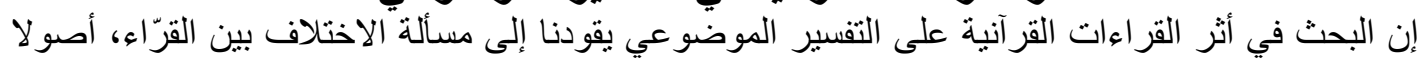

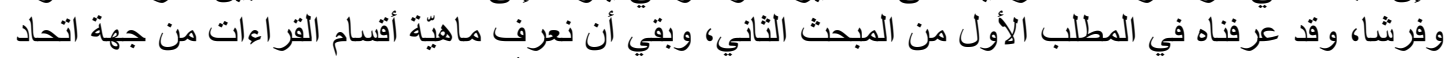

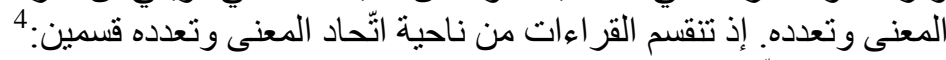

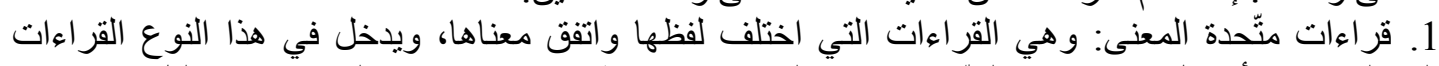

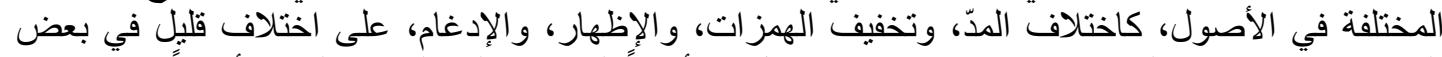

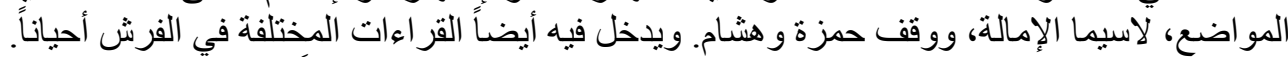

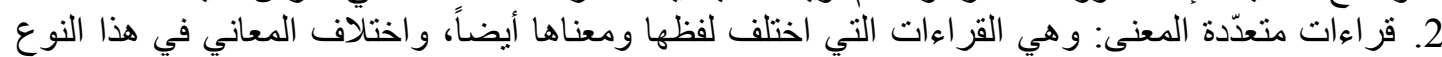

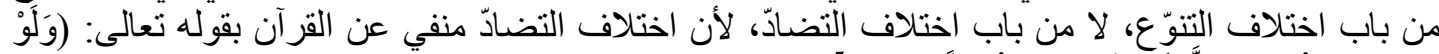

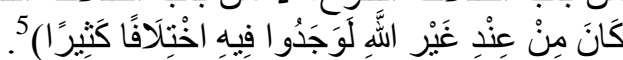

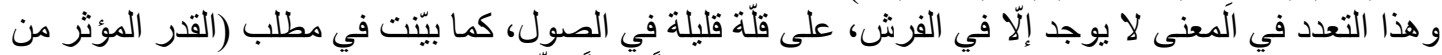

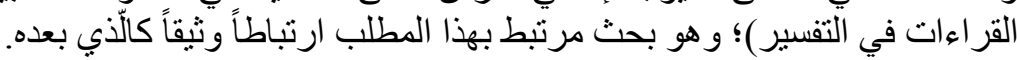

أثر اختلاف القراعات في التفسير الموضوعي:

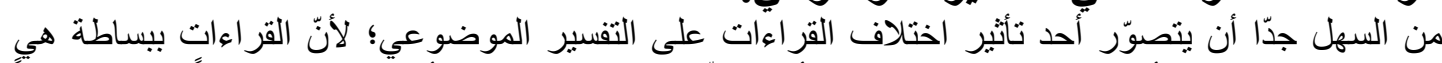

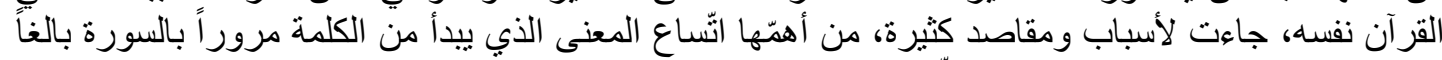
إلى الموضو علف القر آنيّ الثنامل للقر آن كلّه.

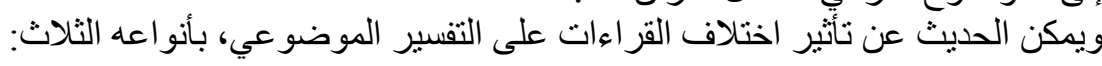

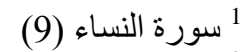

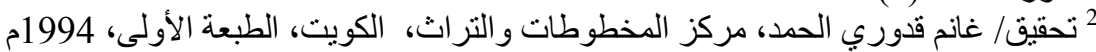

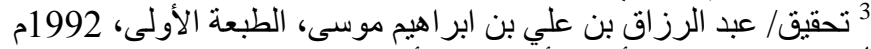

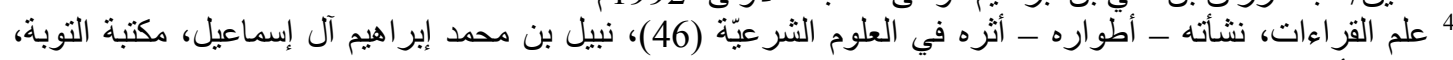

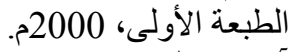
(5 سورة النساء 
1. اثر اختلاف القراعات القرآنية على التفسير الموضوعي للمفردة القرآنية:

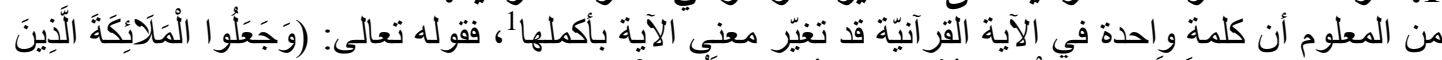

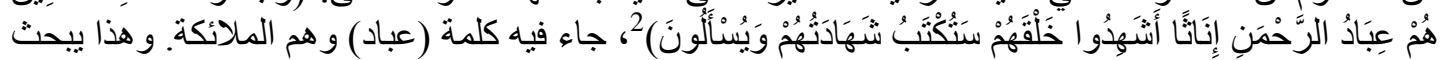

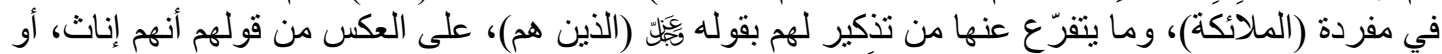

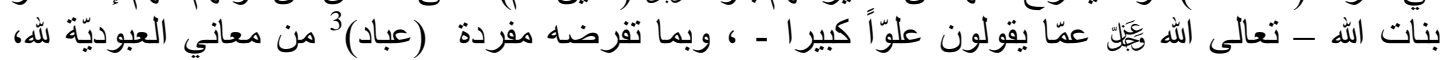

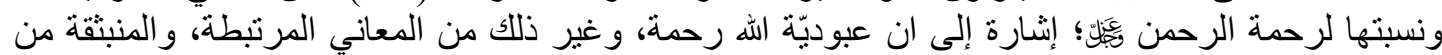

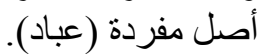

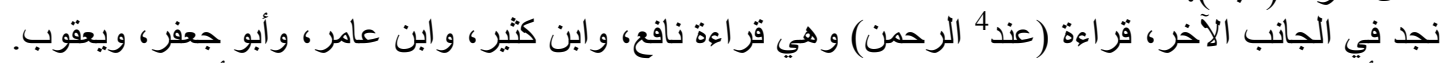

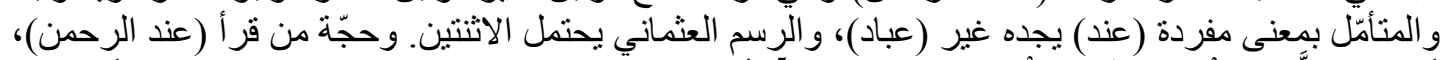

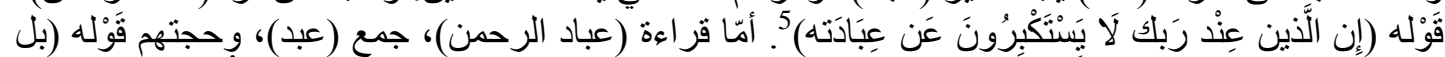

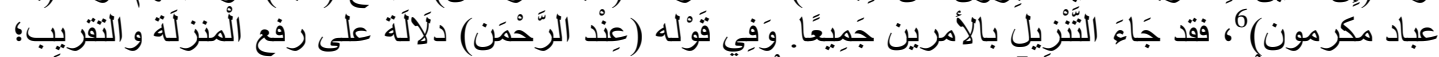

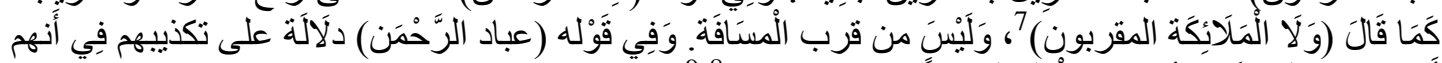

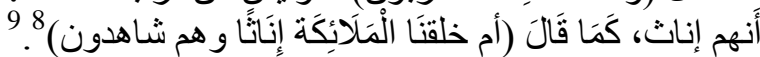

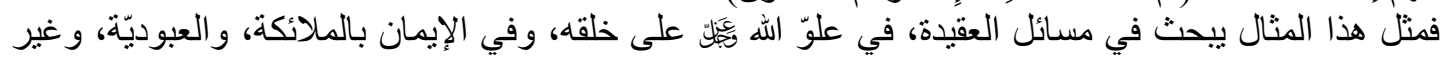

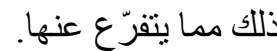

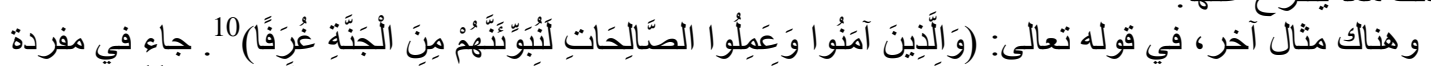

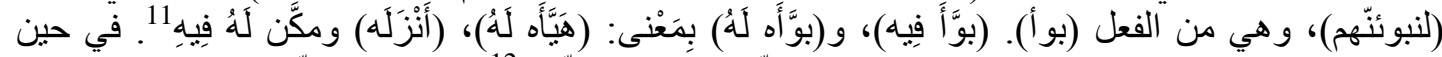

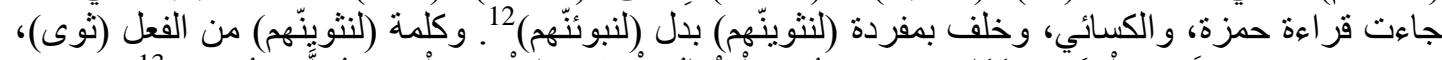

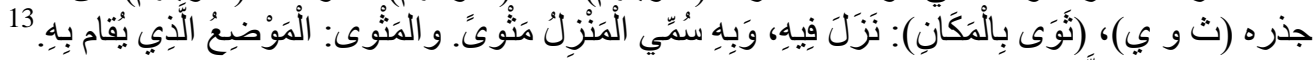

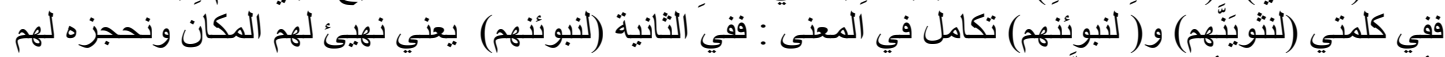

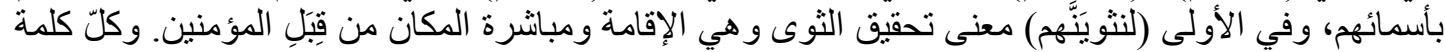

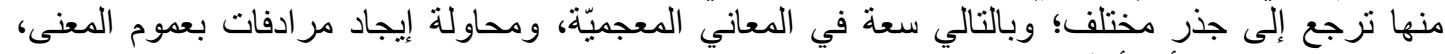
كـ(عدن - ثوىى)، (بوأ - أعدّ). بالإضـافة للمخزون، (لمون الموضوعي لأخبار الجنّة، ومصاديقها من الاحاديث النبويّة، ومقابلتها بأحوال أهل النار، و الفرق بينهما، إلى غير ذلك.

1 مع ما ذكرنا من أن هذا التغيير لا يؤدّي إلى تضاد المعاني

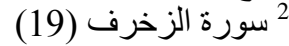

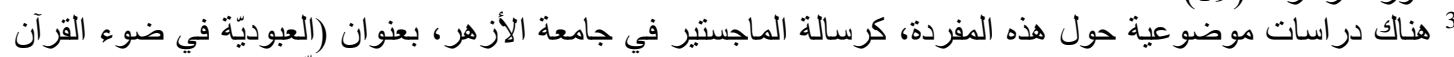
الكريم " دراسة تحليليّة موضوعيّة " ) )، المحمدي عبد الرحمن عبد الله، 2010م. [موقع الكثّاف للرسائل الجامعيّة ] و غير ها كثير. 4 قر اءة (عباد) قر أها الباقون. [ التسهيل لقر اءات التنزيل (490) ] 5 6 (172) سورة النساء 8 سورة الصافات (150)

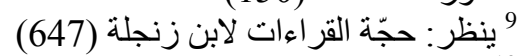

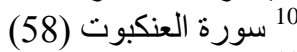

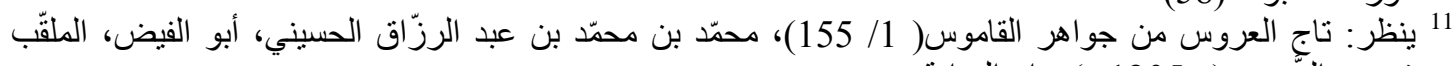

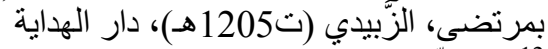

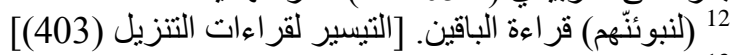

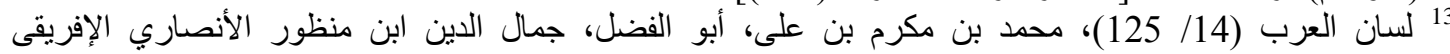

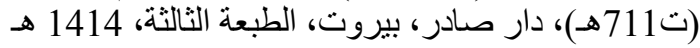


ومن المصنّات التي تعتبر كنز اً في معرفة تأثثير القراءات القر آنية على المفردات العربية:

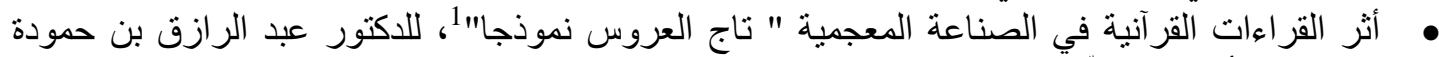

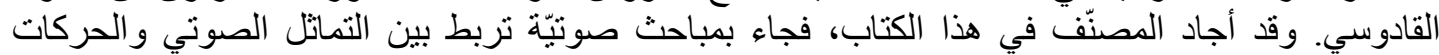

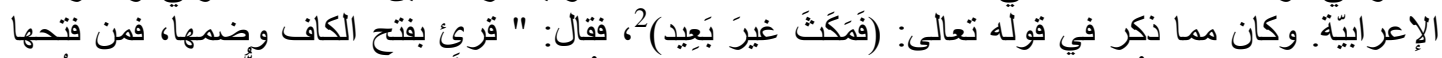

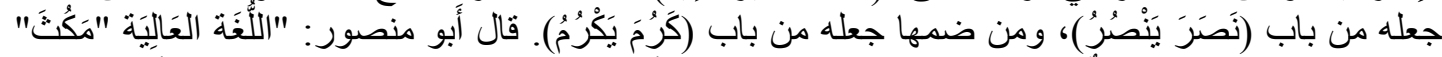

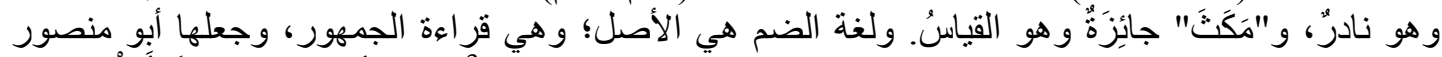

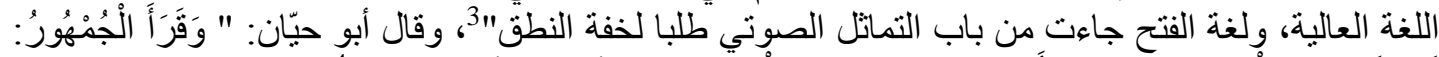

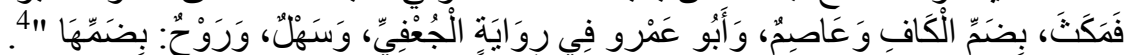

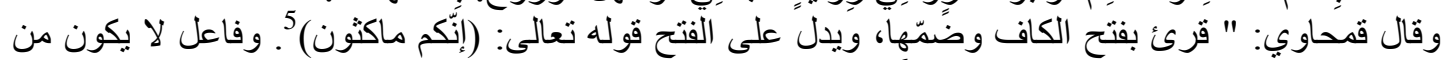

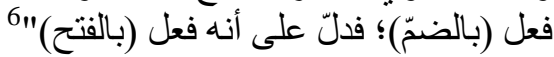

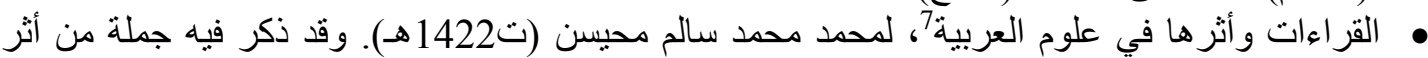

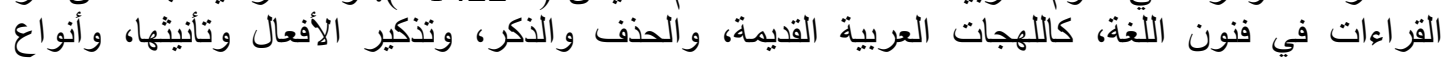

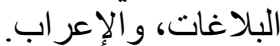

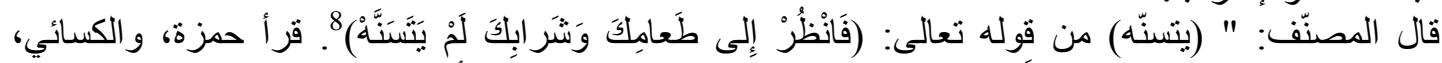

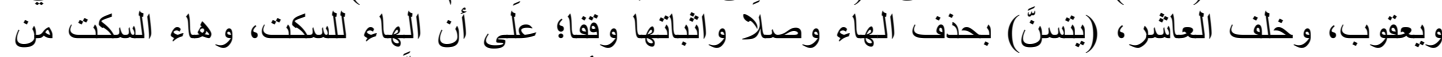

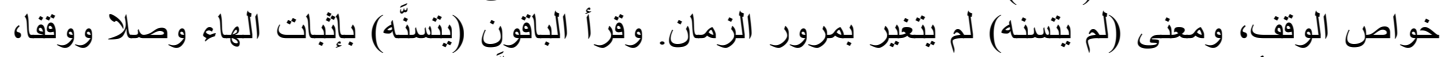

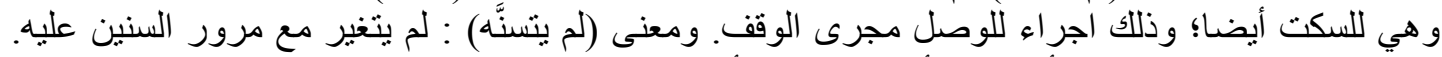

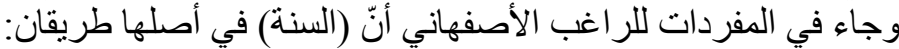

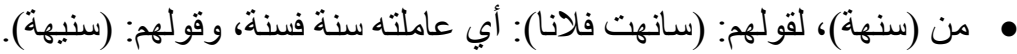

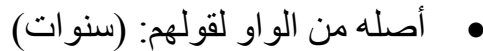

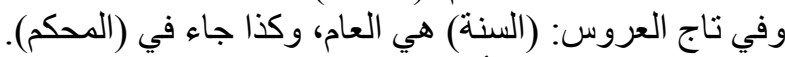

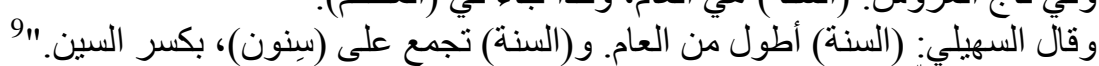

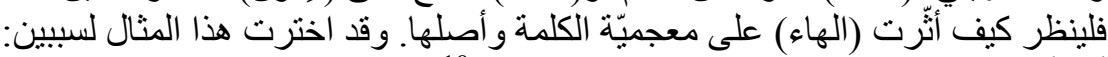

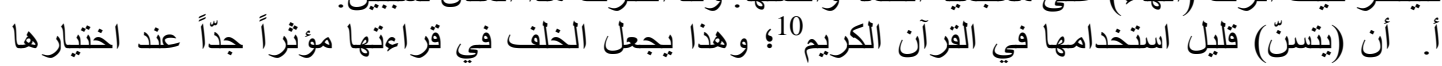
للار اسة الموضو عيّة.

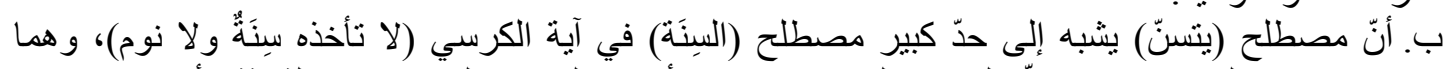

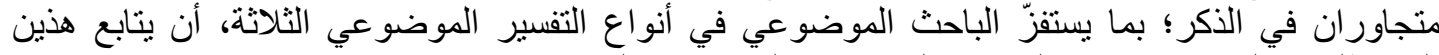

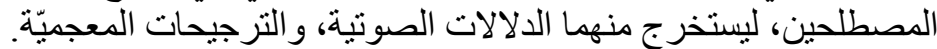

1 رسالة دكتوراه بإثراف الأستاذ الدكتور رجب عبد الجواد إبراهيم- قسم اللغة العربية ـ كلية الآداب ـ جامعة حلوان، 2010

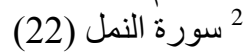

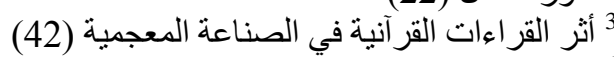

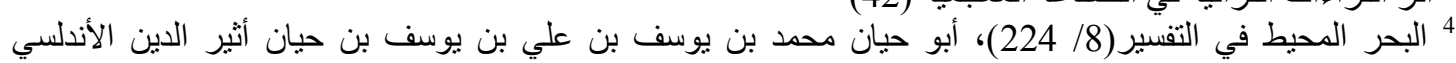
(ت745هـ)، تحقيق/ صدقي محمد جميل، دار الفكر، بيروت، طبعة الفر 1420 هـ

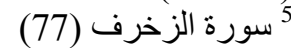
(151) طلائع البشرة الزخرف 7 طبع/ مكتبة الكليات الأزهرية ـ القاهرة، الطبعة الأولى، 1984 م

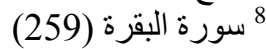

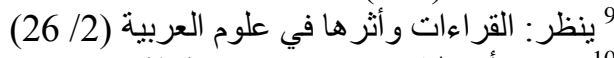

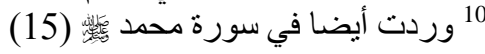


2. اثر اختلاف القراعات القرآنية على التفسير الموضوعي للسورة القرآنية:

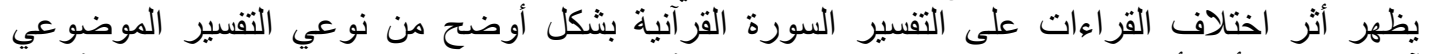

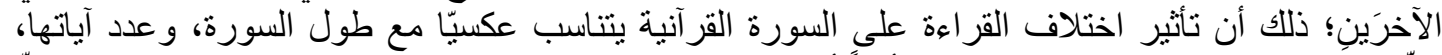

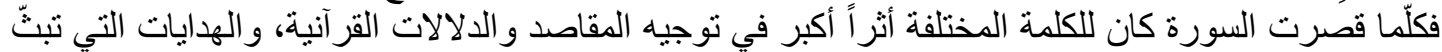

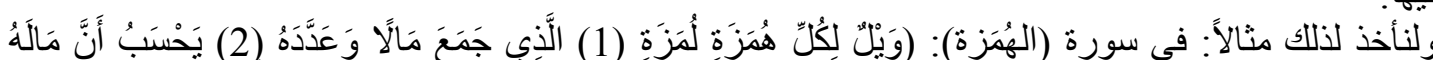

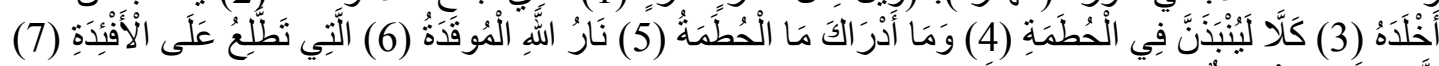

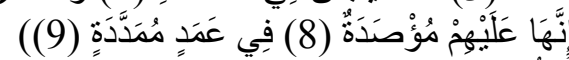

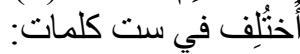

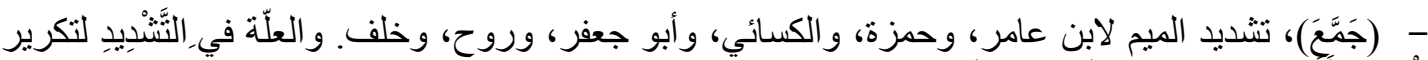

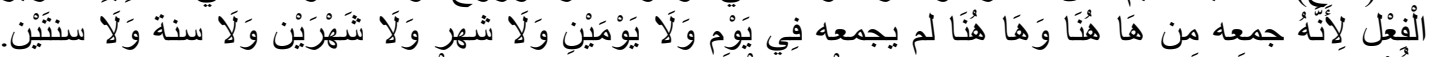

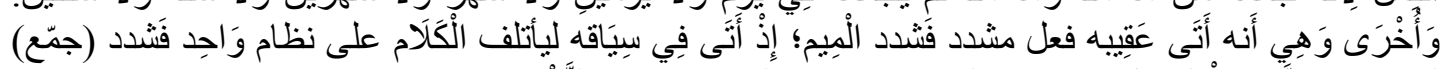

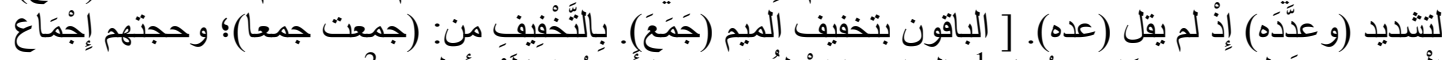

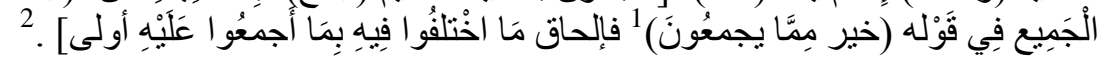

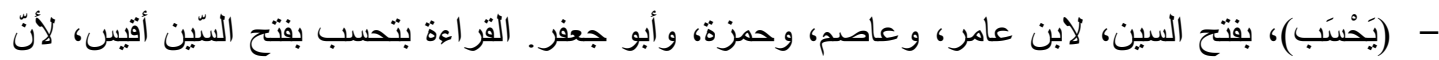

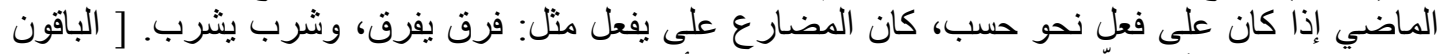

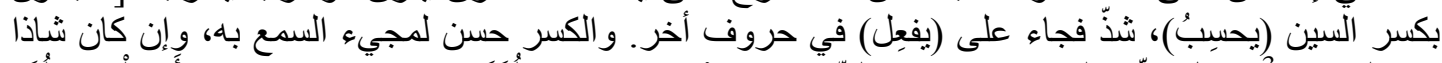

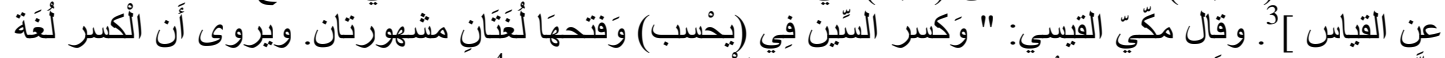

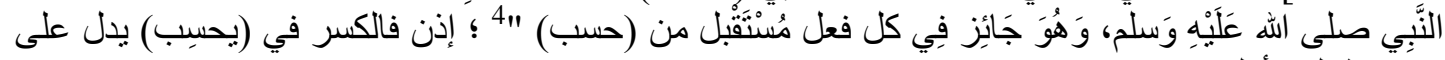

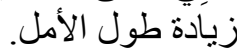

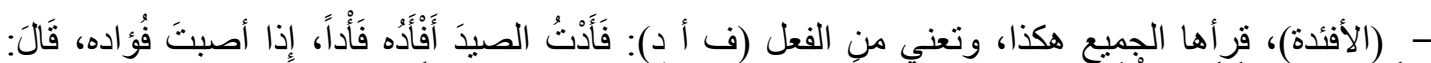

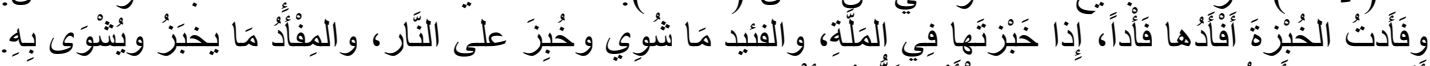

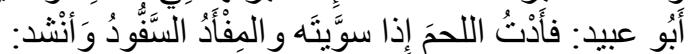

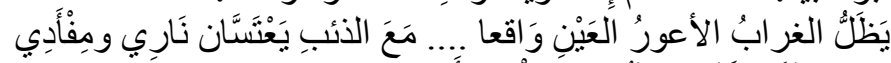

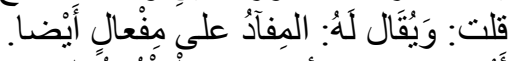

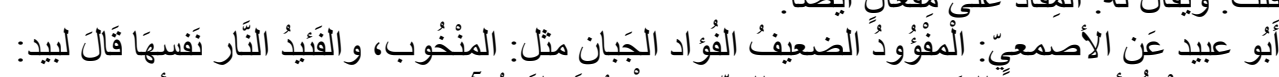

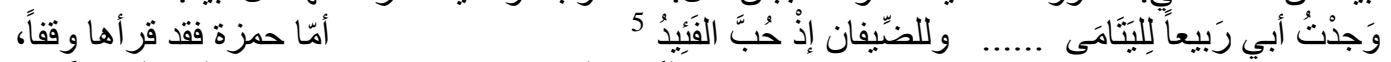

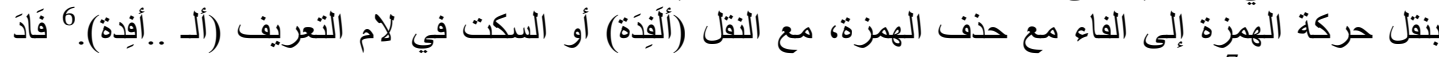

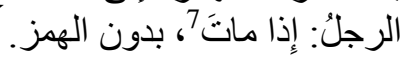

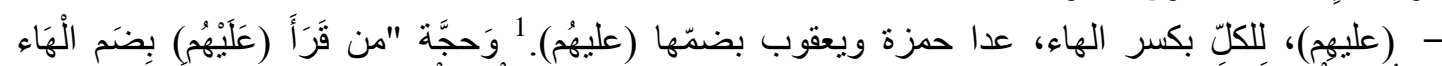

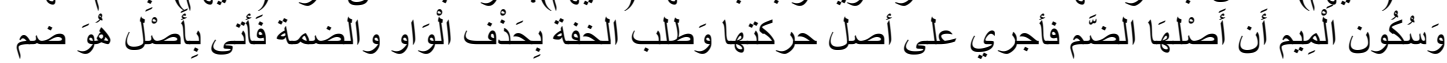

(58) سورة يونس (2) 2 ينظر : حجة القراء (58ات لابن زنجلة (772)، و التسهيل لقر اءات التنزيل (601)، و الحجّة للقرّاء السبعة للفارسي (6 / 441)

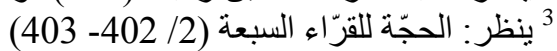

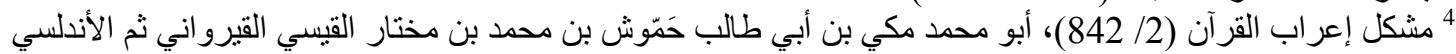

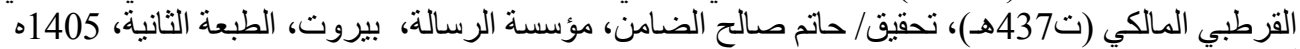

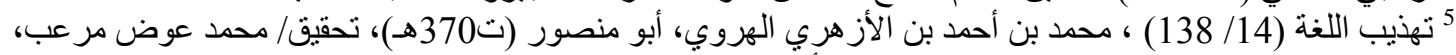

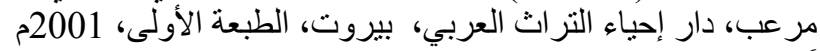
6 (601) 7 تهذيب اللغة (139/ (139) 


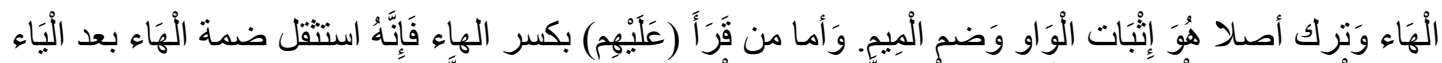

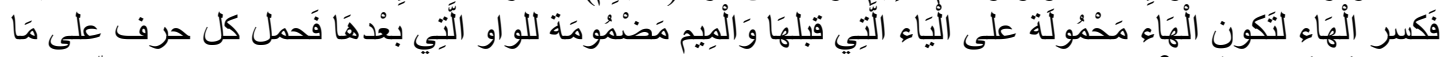

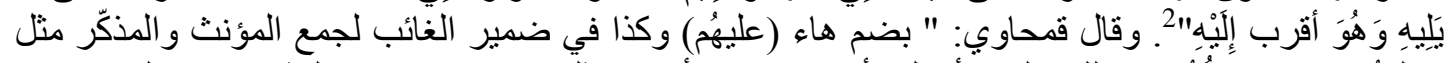

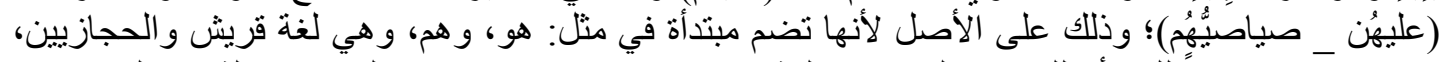

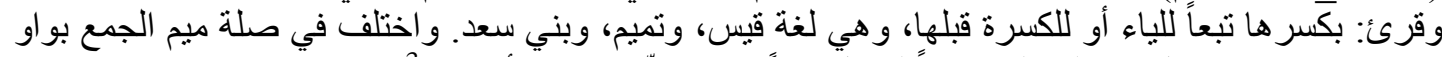

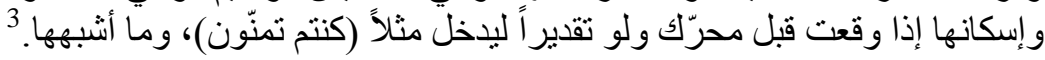

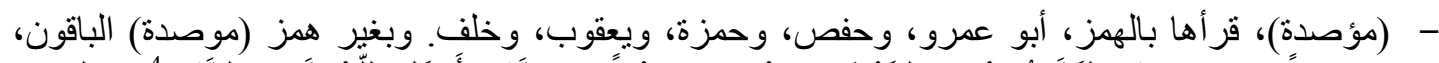

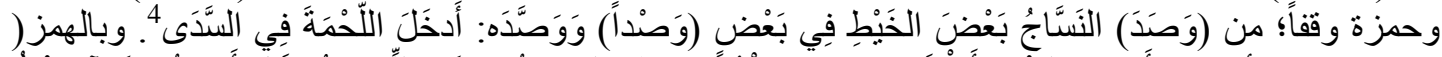

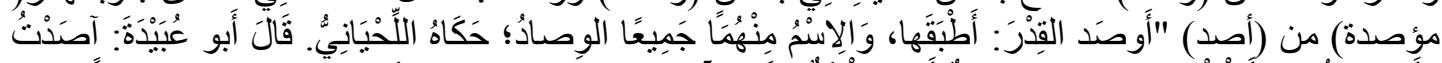

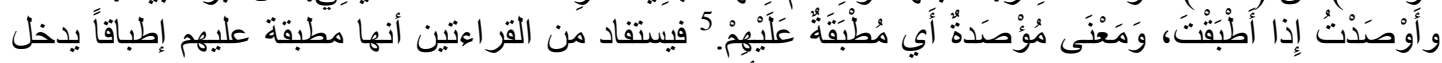

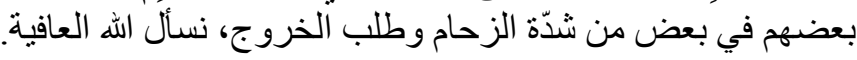

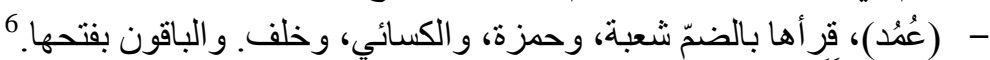

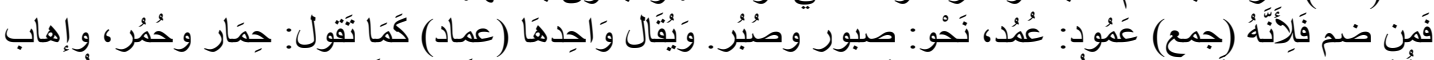

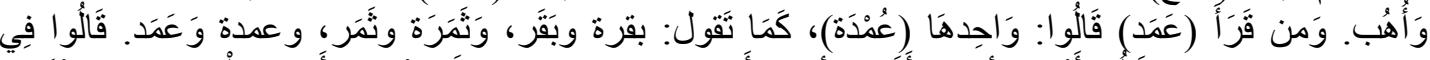

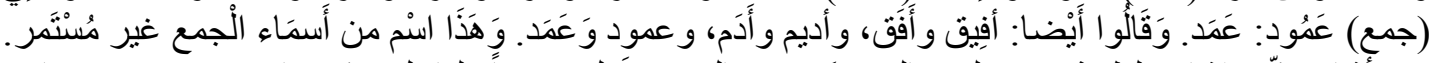

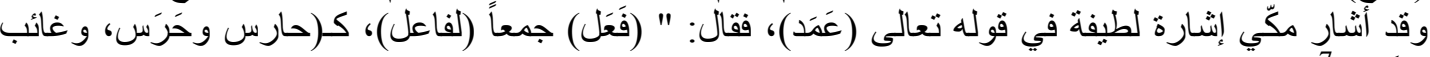

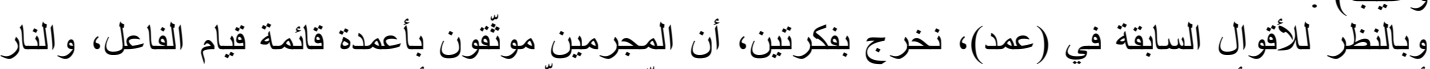

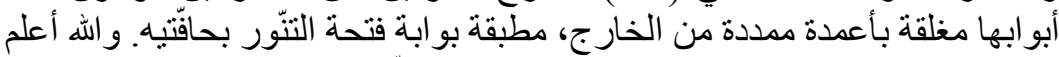

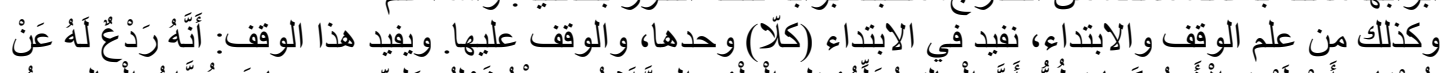

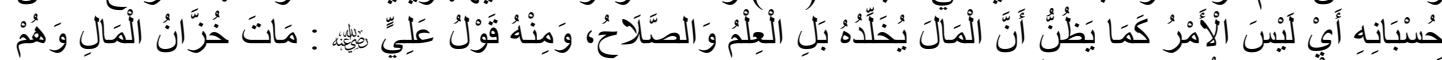

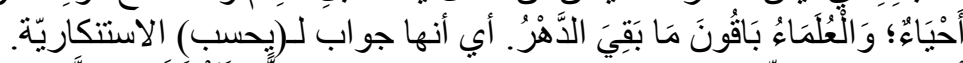

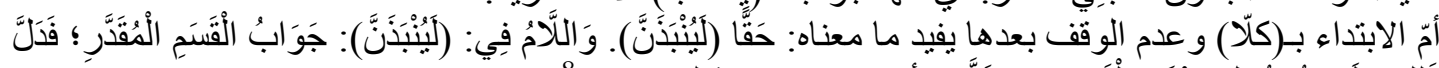

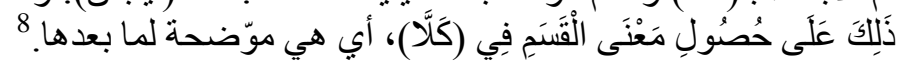

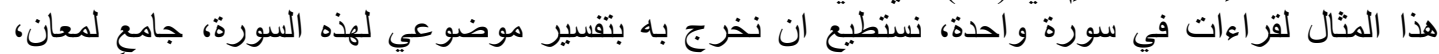

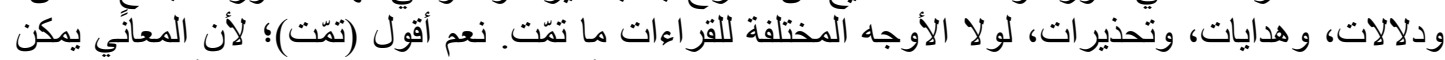

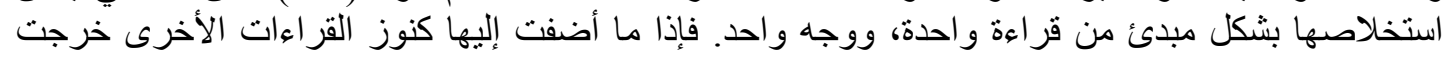

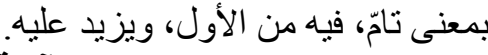

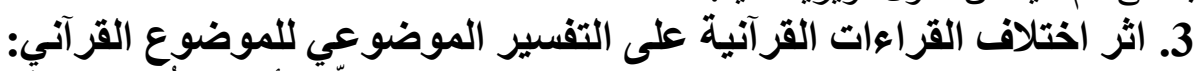

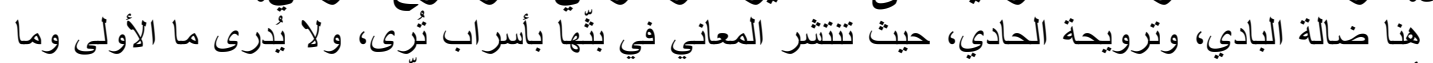

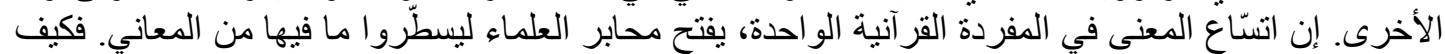

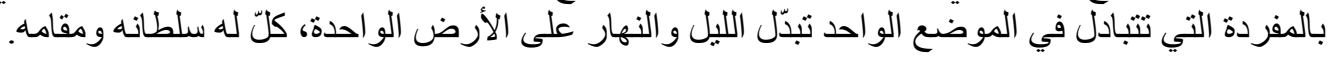

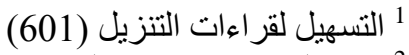

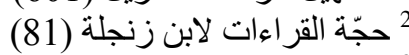

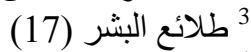

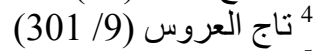
5 ينظر : لسان العرب (301/3 (301) 6 التسعيل لقر اءات التنزيل (601) 8 7 الكثف لركّي القيسيّ (389) 8 ينظر : مفاتيح الغيب (285/32) 
إنّ الحديث عن أثر اختلاف القراءات في الموضوع القرآني، يطول في عجالة البحث، وحسبي أن أشير إلى إنى

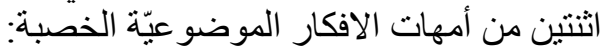

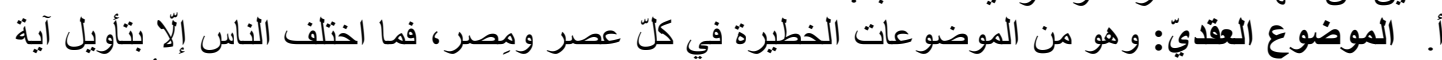

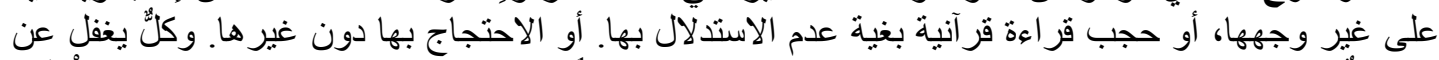

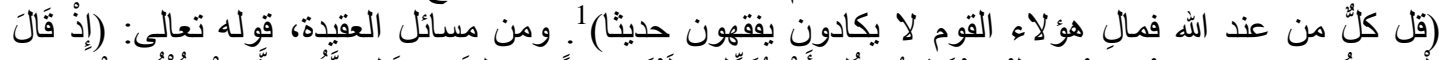

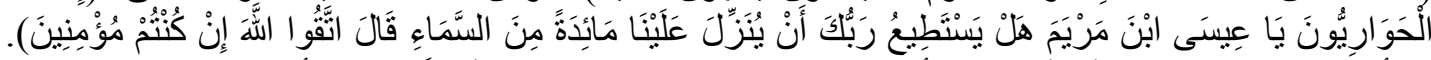

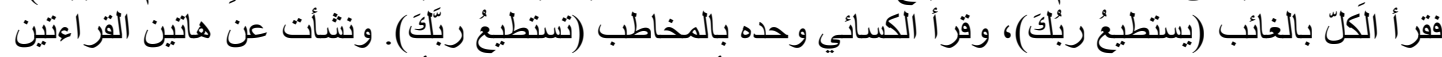

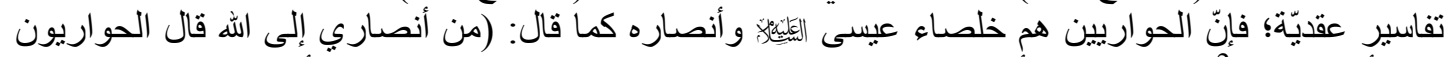

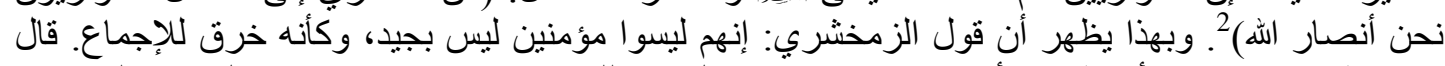

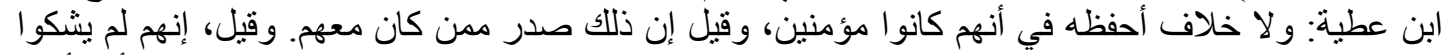

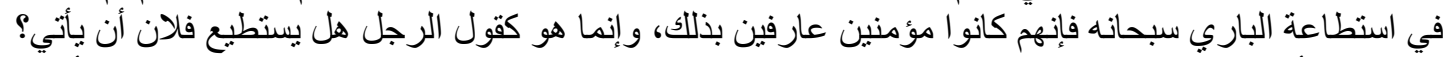

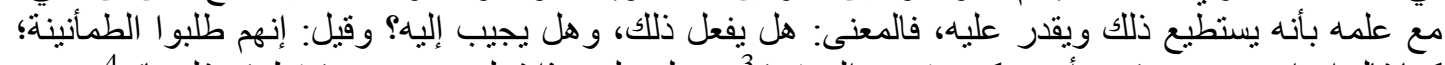

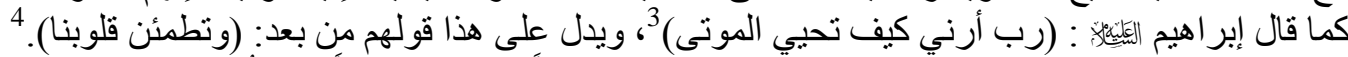

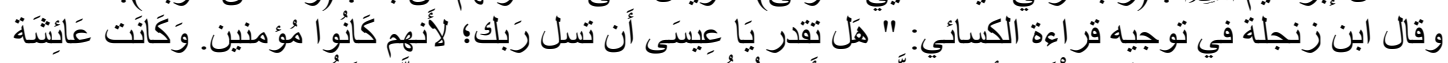

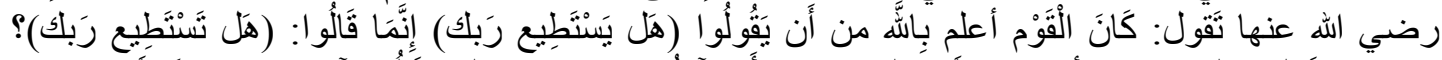

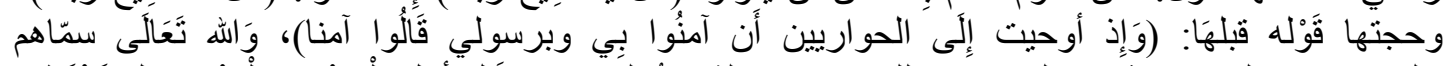

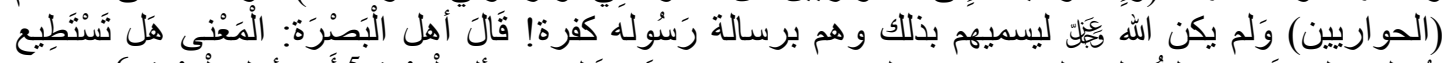

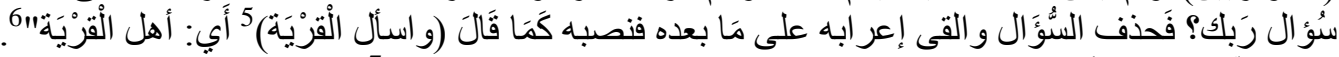

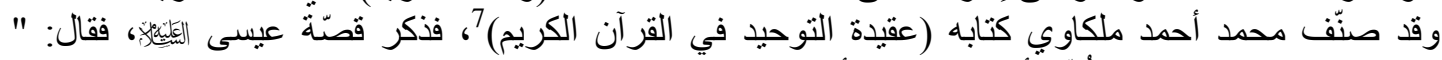

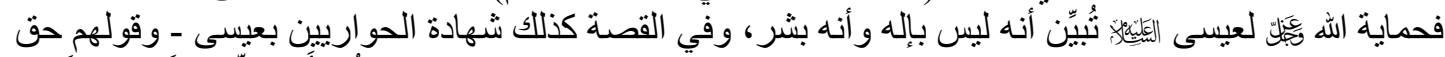

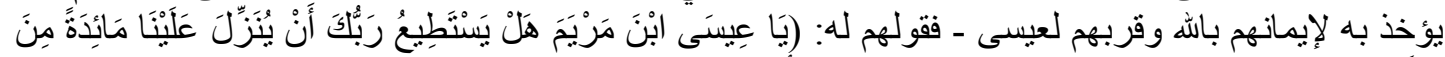

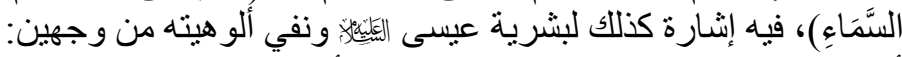

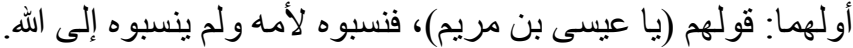

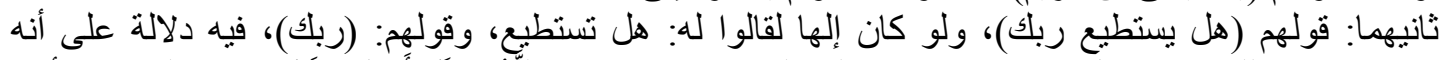

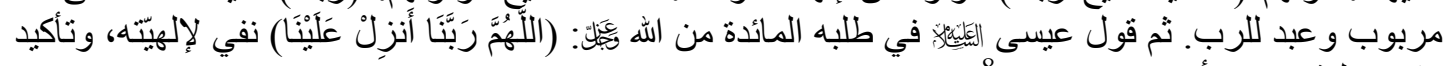

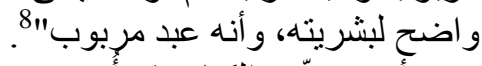

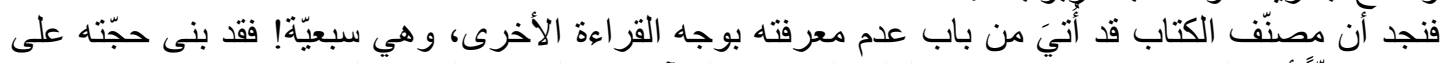

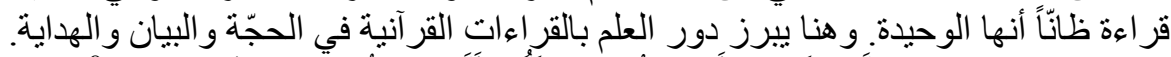

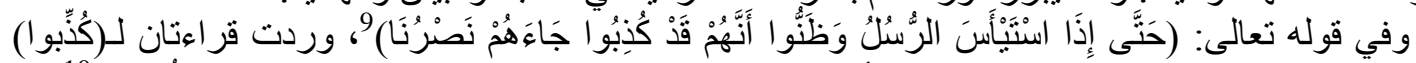

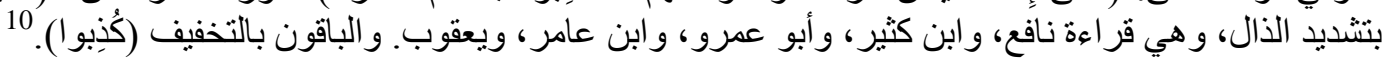

(18) سورة النساء (14) (18)

(14) سورة الصف (18)

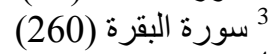

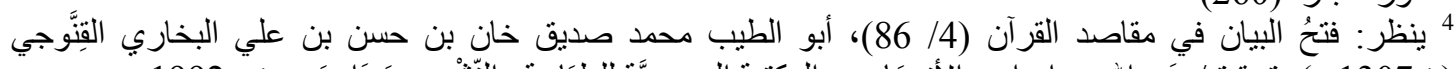

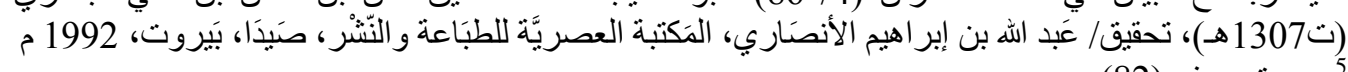

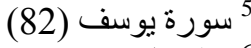

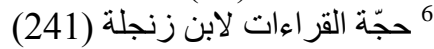

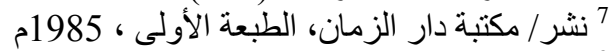

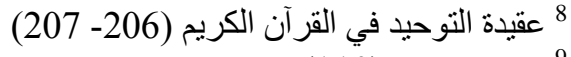
9ورة يوسف (110)

10 التسهيل لقراءات التنزيل (248) 


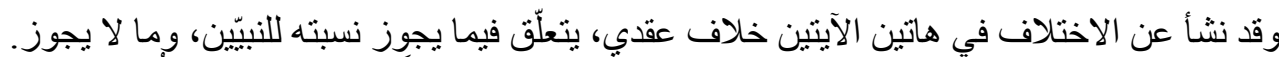

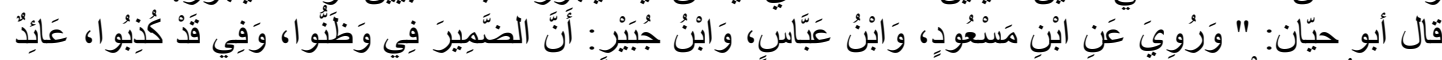

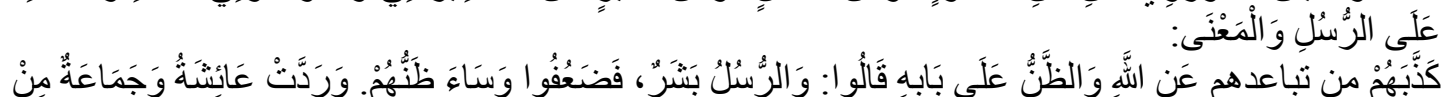

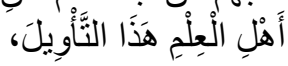

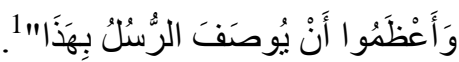

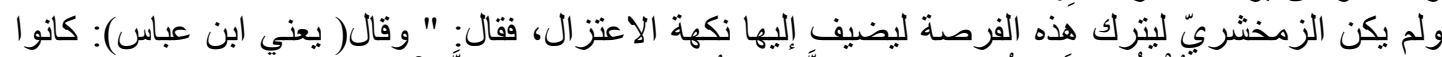

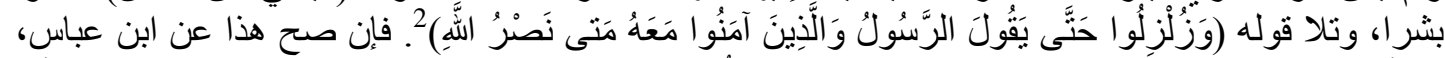

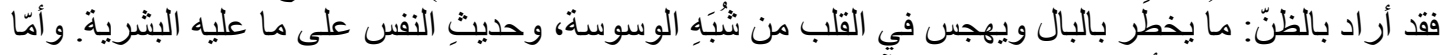

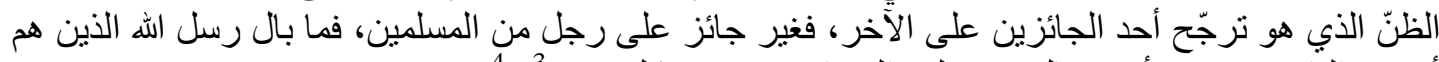

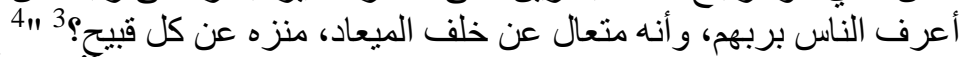

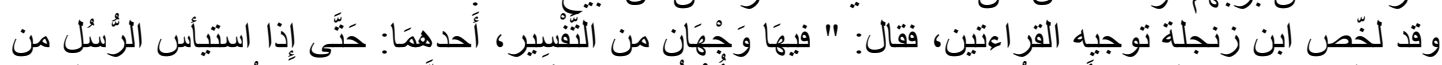

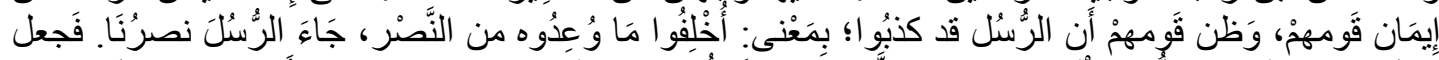

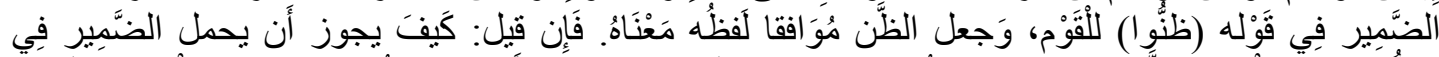

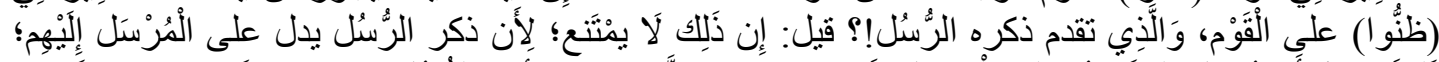

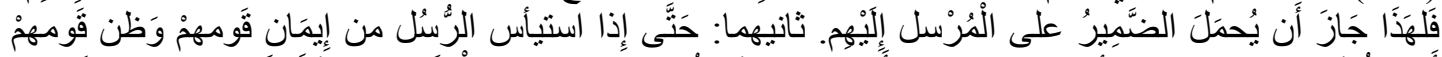

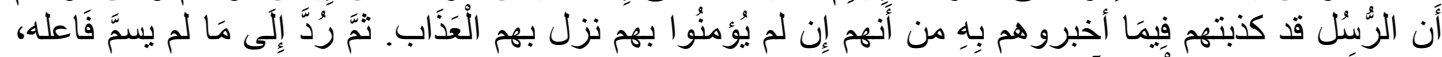

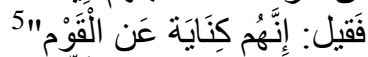

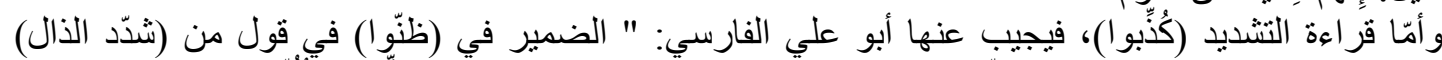

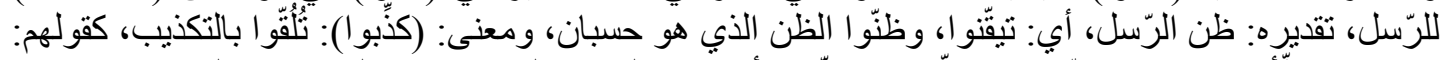

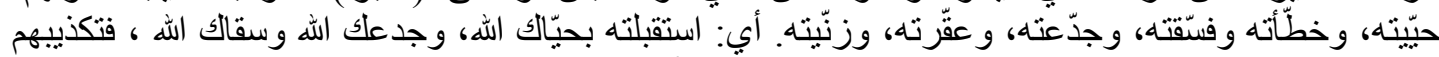

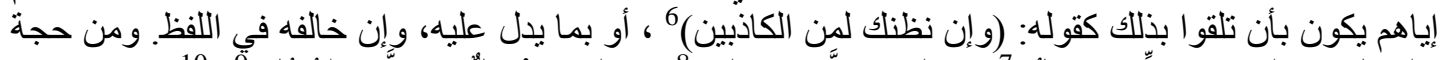

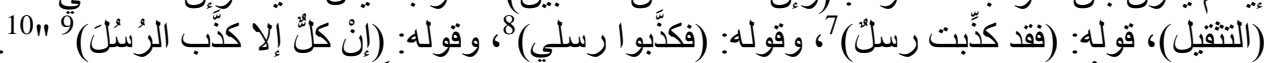

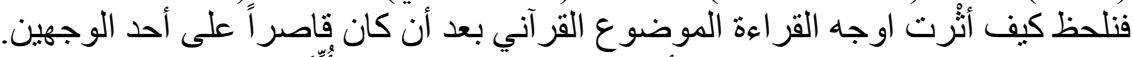

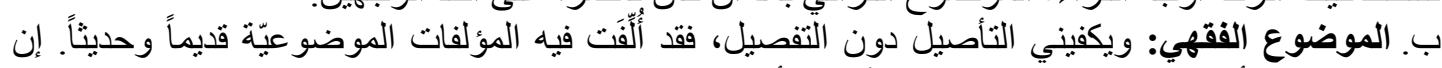

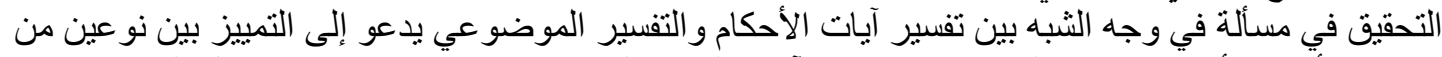

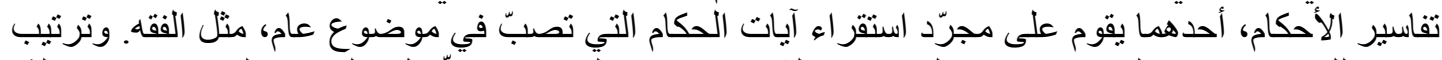

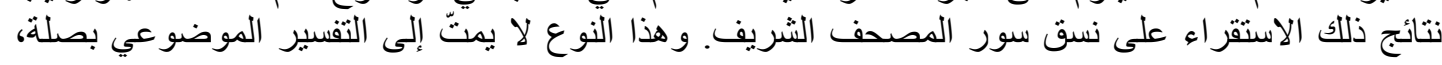

1 البحر المحيط (214) (336) (20)

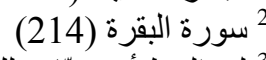

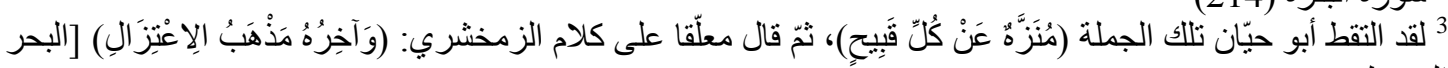

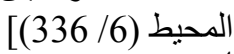
4 الكثاف عن حقائق غو امض التنزيل (236/ 510)، أبو القاسم محمود بن عمرو بن أحمد، الزمخثري جار الله (ت538هـ)،

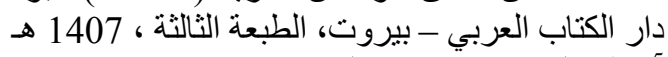

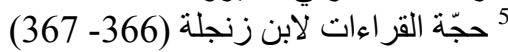

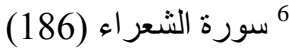
(4) (4) سورة فاطن

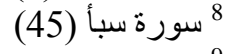

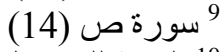

10 الحجة للقراء السبعة (4/ 441- 442) 
بخلاف ما لو كان تصنيف تللك النتائج على العناوين الفرعيّة لذلك الموضوع؛ فالأوّل تجزيئي تسلسلي و الآخر

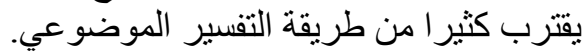

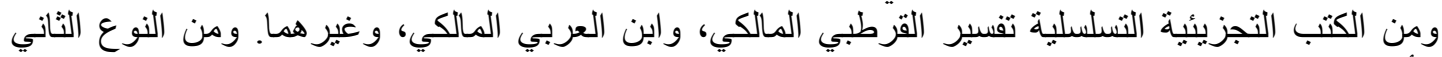

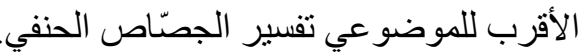

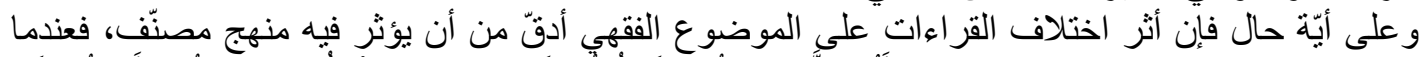

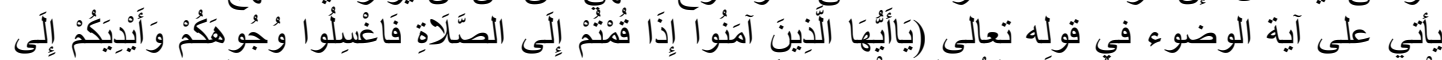

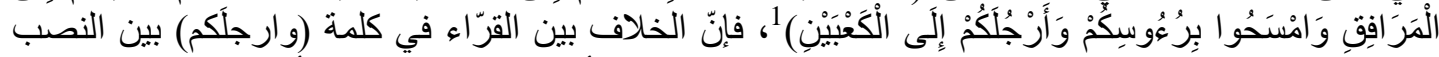

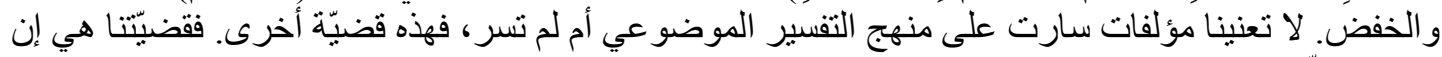

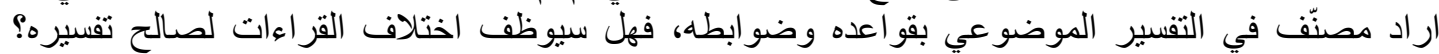

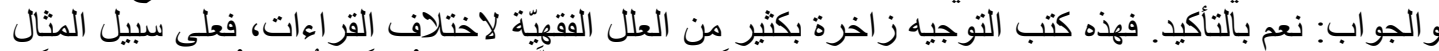

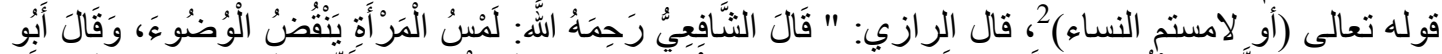

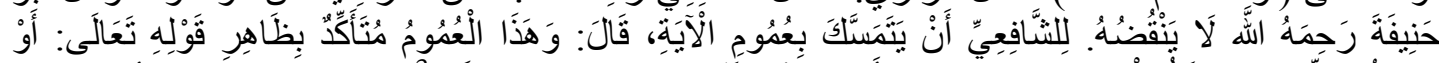

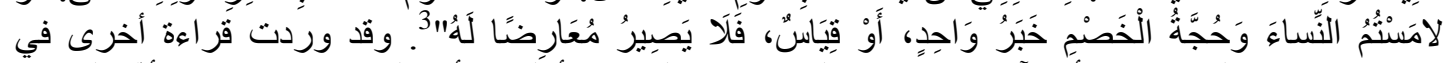

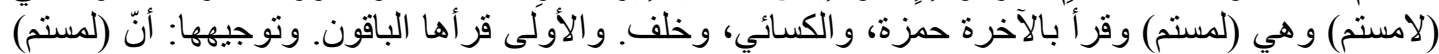

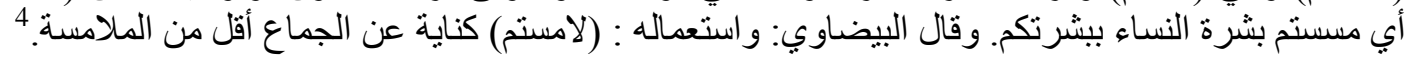

إنّ معرفة القراءات القر آنيّة يفتح أبواباً موصدة في دراسات التفسير الموضوعي، لا تفتّحُ إلّا بإتقانها، وبما

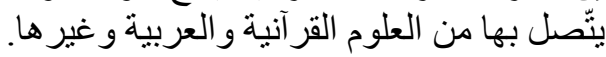

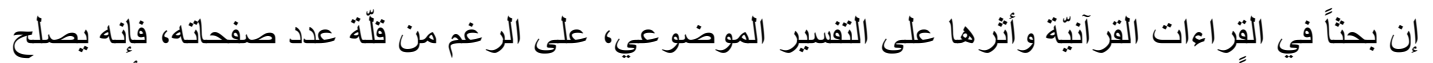

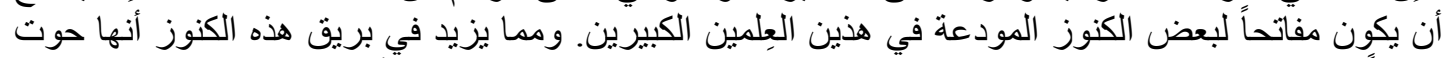

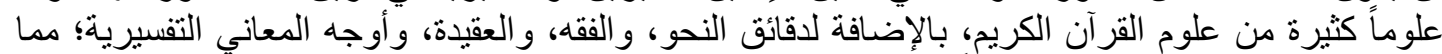

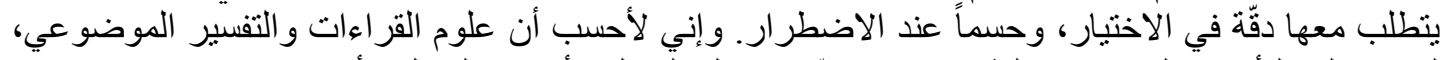

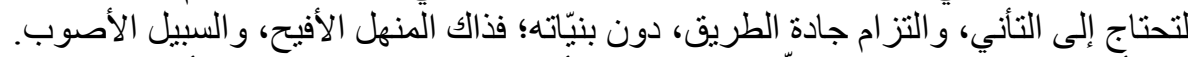

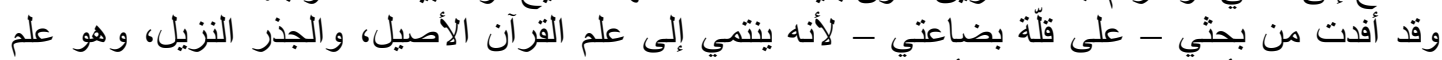

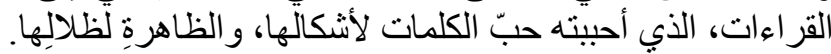

تبت المظان

القرآن الكريم الميط

1. المعجم الوسيط، مجمع اللغة العربية بالقاهرة، (إبر اهيم مصطفى / أحمد الزيات / حامد عبد القادر / محمد النجار)، دار الدعوة

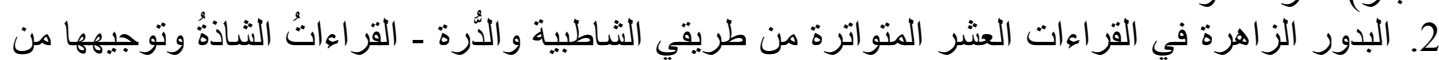

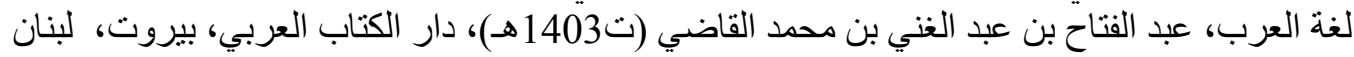

1 سورة المائدة (6). قرأها بالفتح نافع ، وابن عامر، وحفص، و الكسائي، ويعقوب. وقرأها الباقون بالخفض.(و المسألة

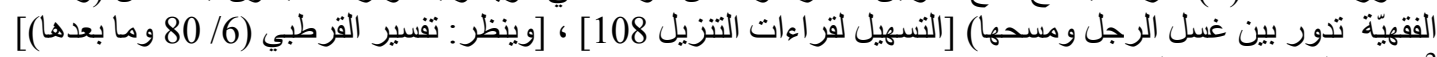

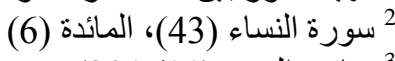

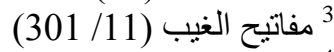

(55) (5لائع البشع الغبر) 
3. الإقناع في القراءات السبع، أحمد بن علي بن أحمد بن خلف الأنصاري الغرناطي، أبو جعفر، المعروف

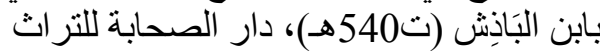

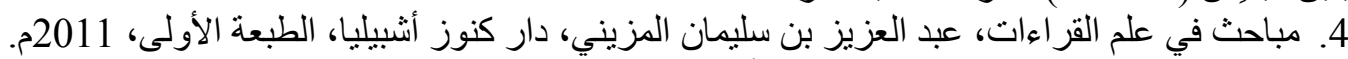

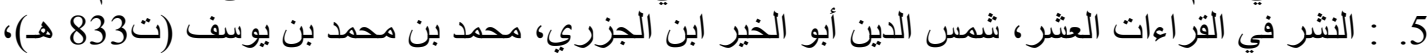

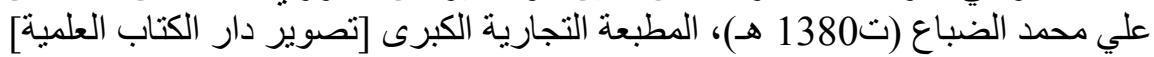

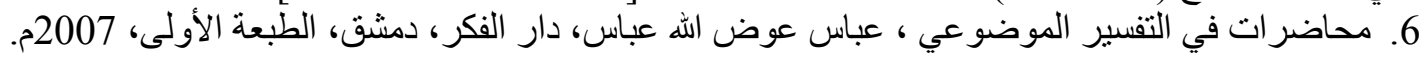

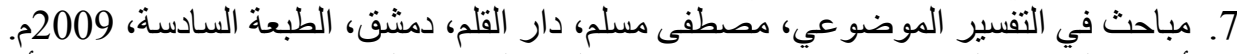

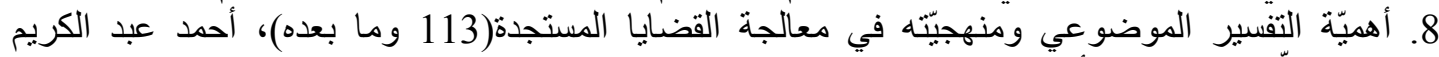

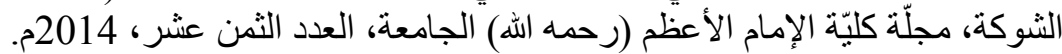
9. التفسير الموضوعي بين النظريّة والتطبيق، صلاح عبد الفتّاح الخالدي، دار النفائس، الأردن، الطبعة الثالثة، 2012

10. إبراز المعاني من حرز الأماني، أبو القاسم شهاب الدين عبد الرحمن بن إسماعيل بن إبر اهيم المقدسي

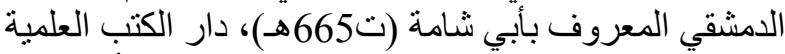

11. مقدمات في علم القر اءات، محمد القضاة ــ أحمد خالد شكري ـ محمد خالد منصور ، دار عمّار، الطبعة

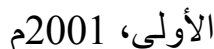

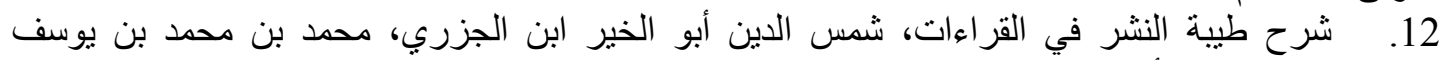

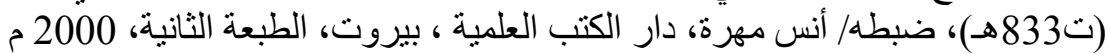

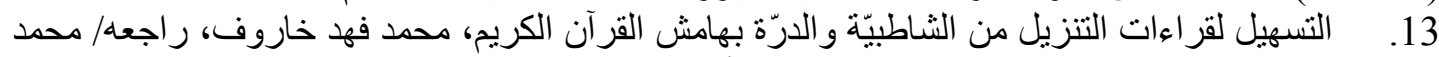

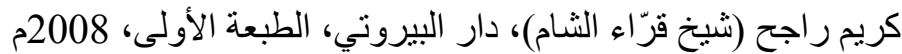

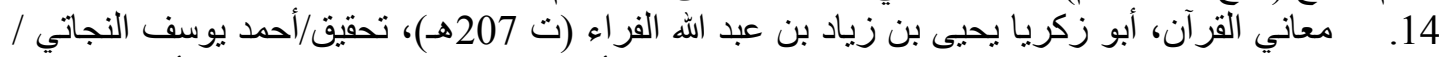

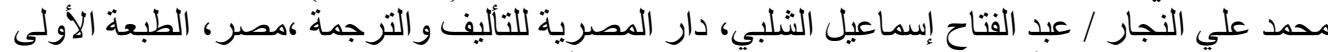

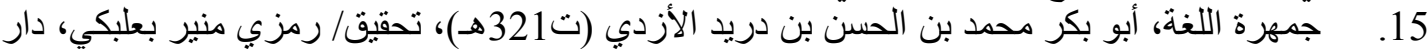

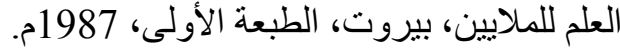

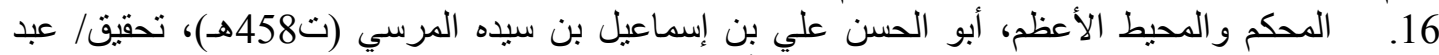

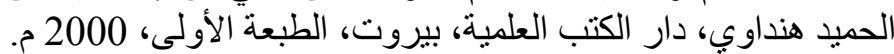

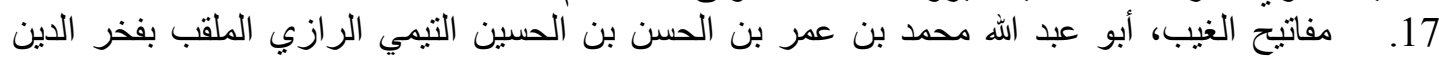

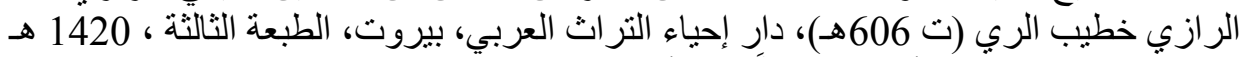

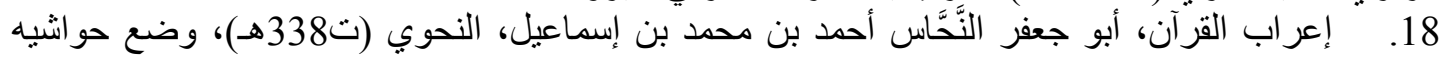

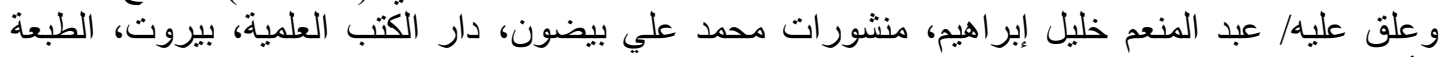

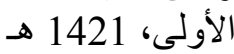

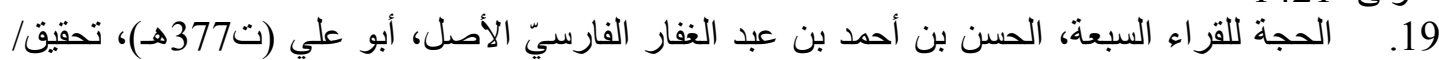

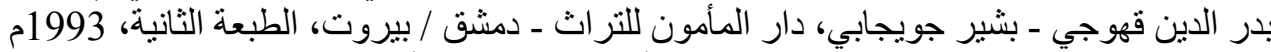

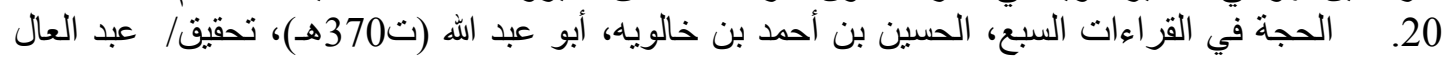

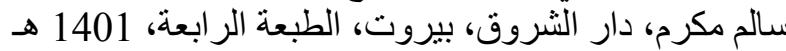

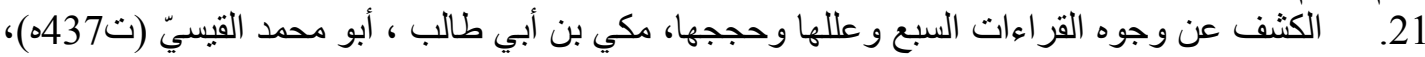

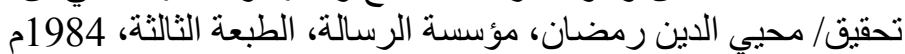

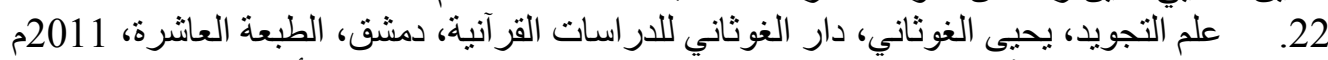

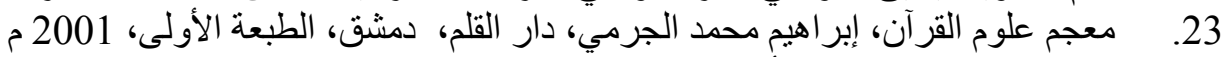

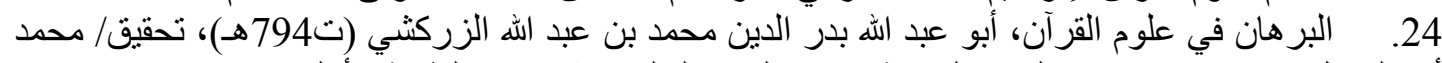

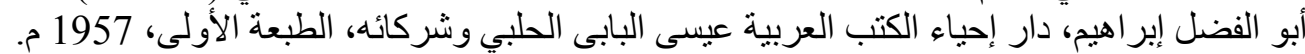

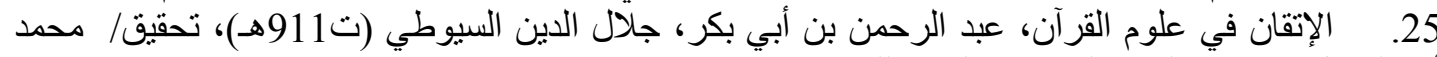
أبو الفضل إبر اهيم، العيئة المصرية العامة للكتاب، 1974 م 
26. التفسير الموضوعي ـ التأصيل والتنثيل، زيد عمر العيص، دار مودّة، القاهرة، الطبعة الثانية

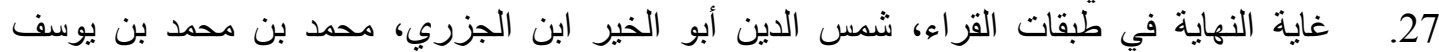
(ت833هـ)، مكتبة ابن تبمية فية النية

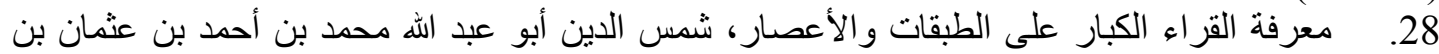

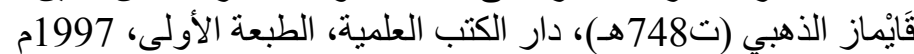

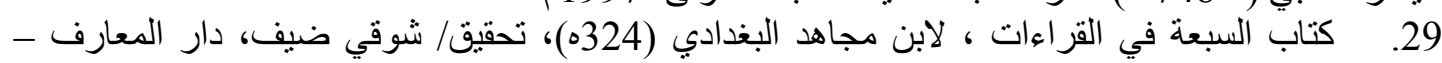

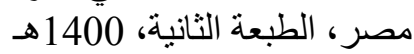

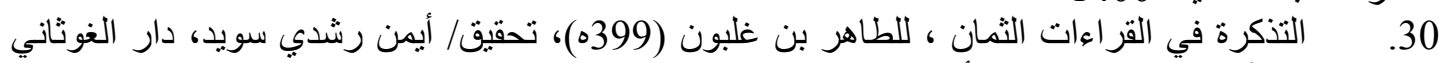

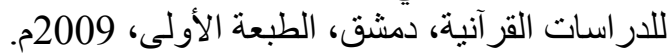

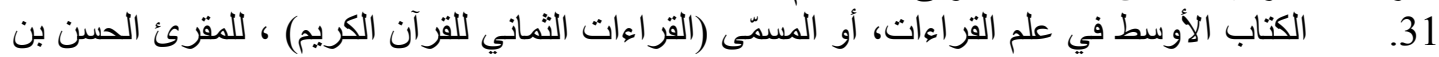

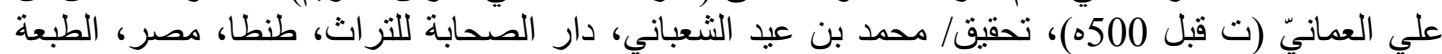

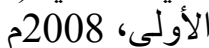

32. كتاب التبصرة في القراءات السبع ، لأبي محمد مكّيّ القيسي (437ه)، تحقيق/ جمال الدين محمد

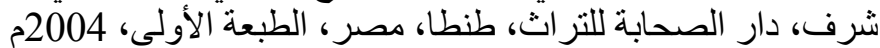

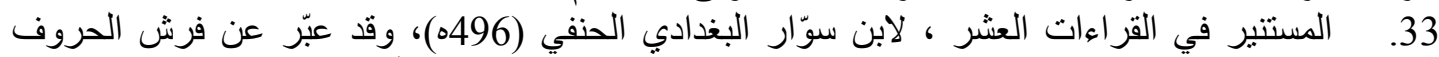

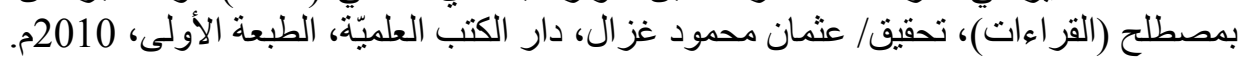

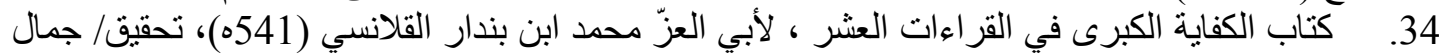

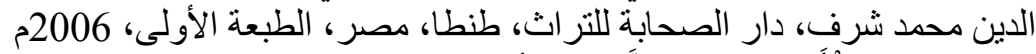

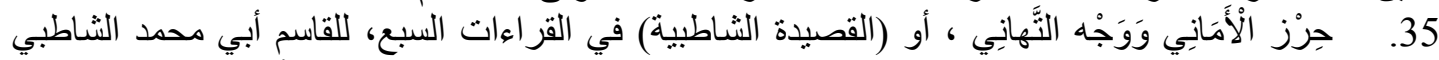

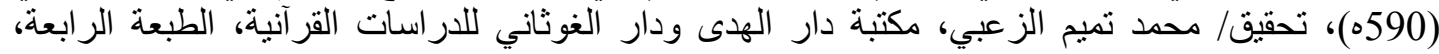
2005

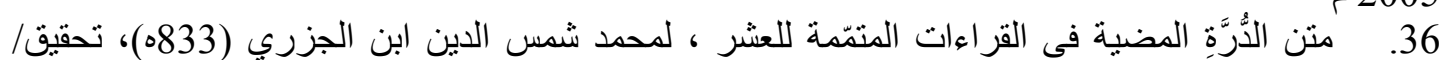

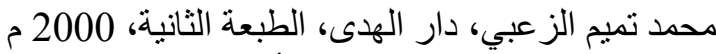
37. المنظومة الخاقانيّة ، لأبي مز احم موسى بن عبيدة الله بن خاقان (325ه)، تحقيق/ حازم بن سعيد السعيد، دار عمّار 38. الرعاية لتجويد القراءة وتحقيق لفظ التلاوة ، لأبي محمد مكّيّ القيسي (437ه)، تحقيق/ أحمد حسن

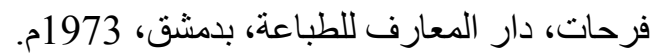

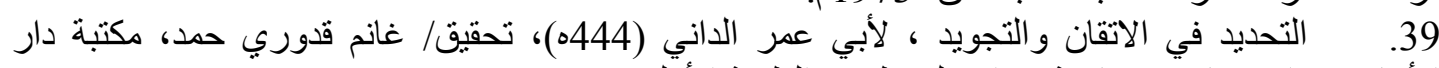

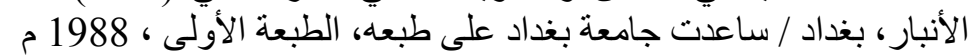

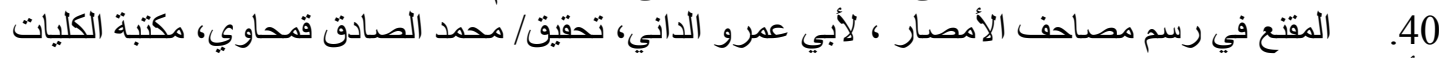

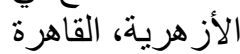

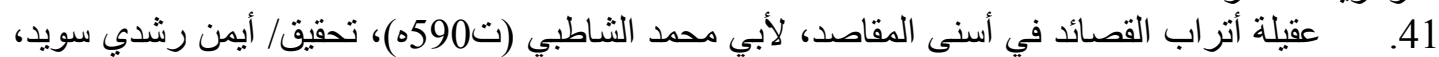

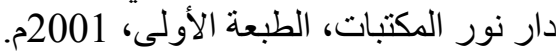

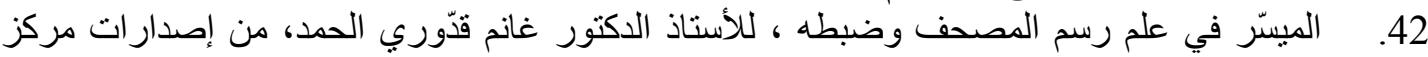

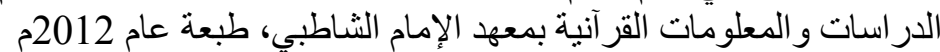

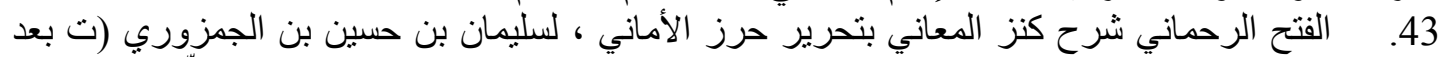

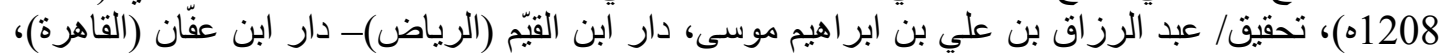

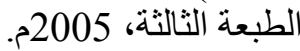

44. اتحاف البريّة بتحريرات الثاطبية ، لحسن خلف الحسيني (1342ه)، الكتاب من إصدار دار الصحابة

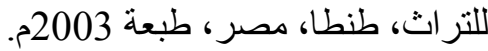

45. مختصر طلو، ملوغ الأمنية، على محمد الضباع (1380ه)، تحقيق/ جمال محمد شرف، ، دار الصحابة للتراث، طنطا، مصر ، الطبعة الأولى، 2004م. 
46. المكتفى في الوقف و الابتدا، عثمان بن سعيد بن عثمان بن عمر أبو عمرو الداني (ت444هــ)، تحقيق/

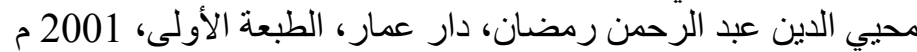

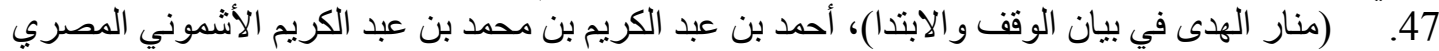

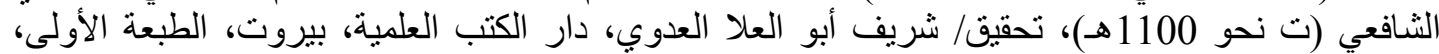

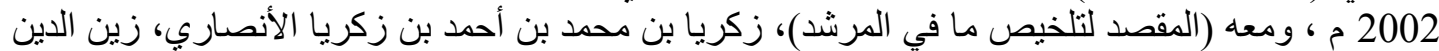

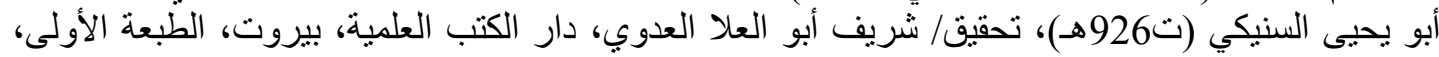
2002

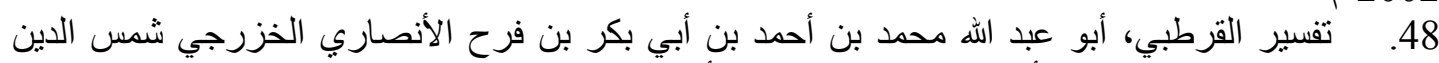

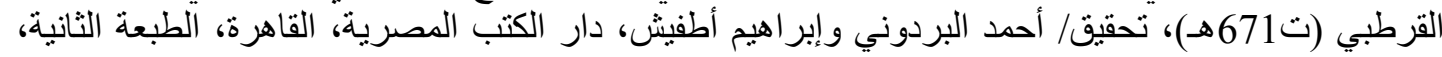

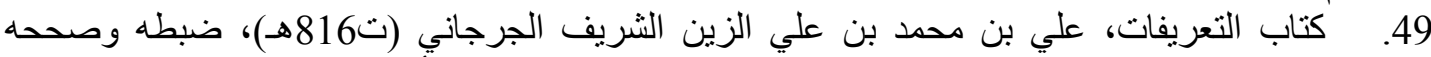

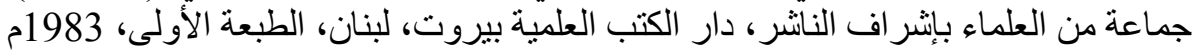

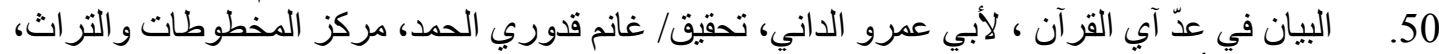

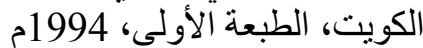

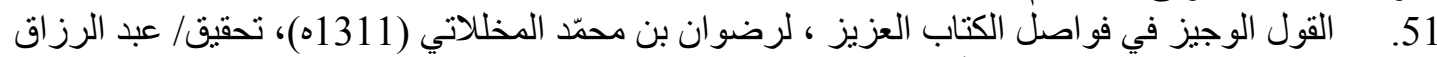

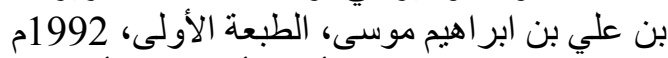

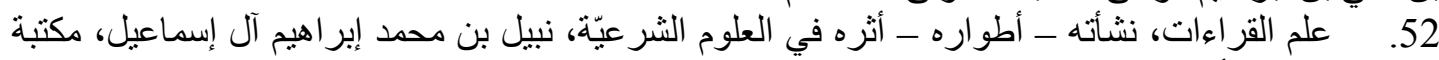

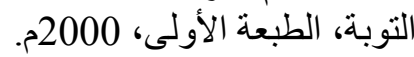

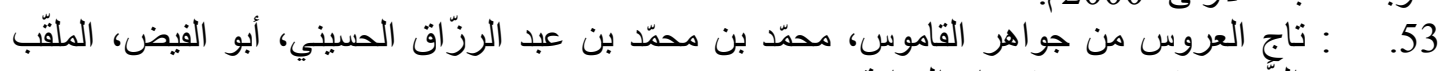

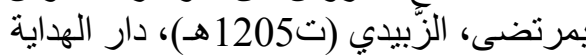

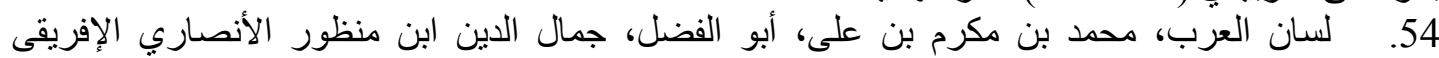

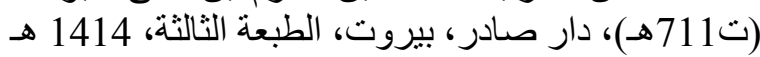

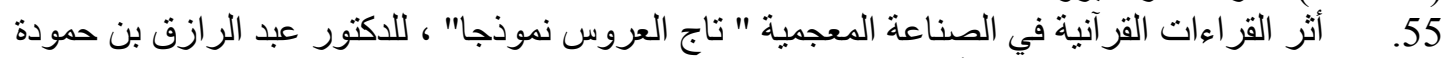

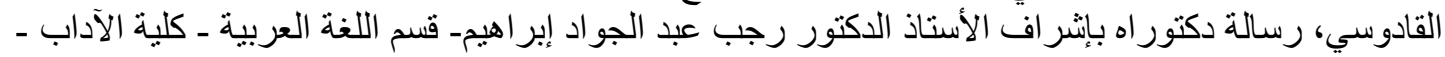

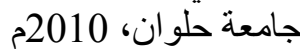
56. البحر المحيط في التفسير، أبو حيان محمد بن يوسف بن على علي بن يوسف بن حيان أثثر الدين الأندلسي

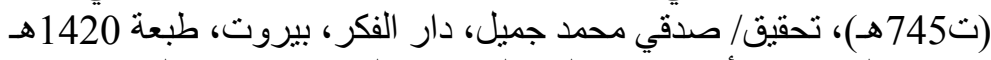

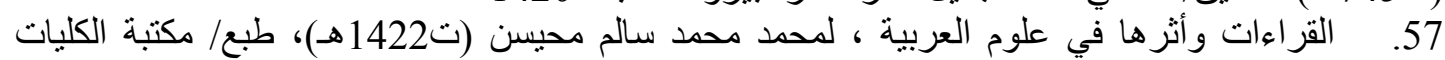

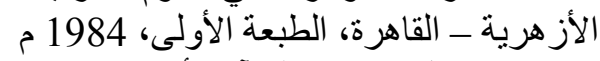

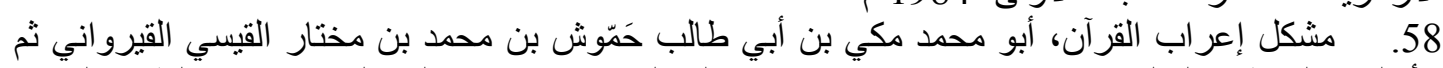

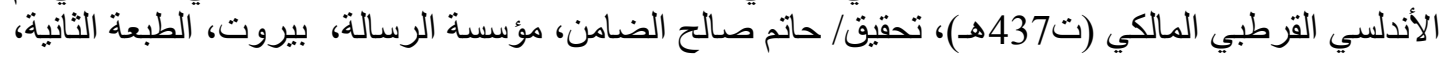
.1405

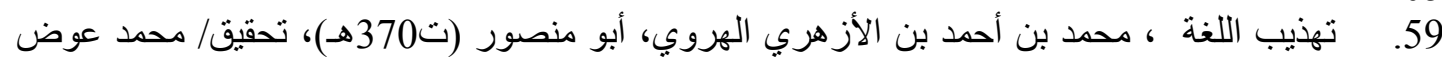

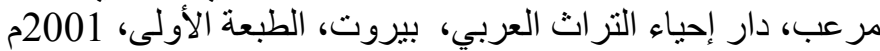

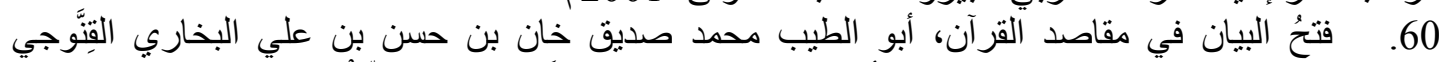

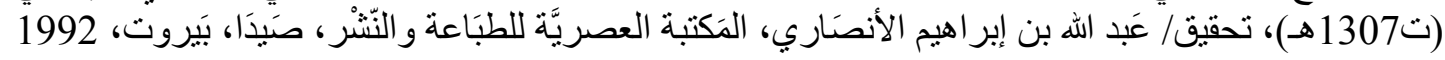

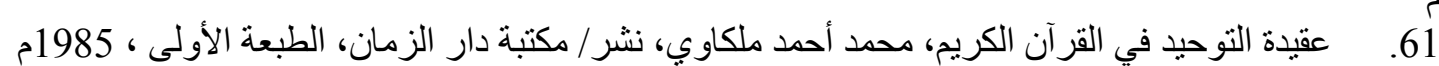

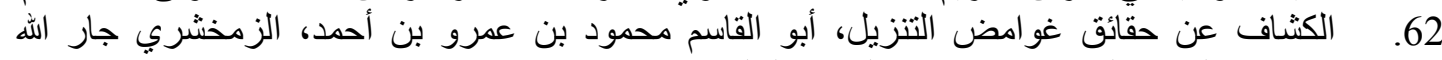
(ت538هـ)، دار الكتاب العربي - بيروت، الطبعة الثالثة ، 1407 هـ 142 